University of Rhode Island

DigitalCommons@URI

Open Access Master's Theses

1992

\title{
GUIDE PLAN FOR THE REDEVELOPMENT OF SLATERSVILLE, R.I.
}

Lisa B. Wray

University of Rhode Island

Follow this and additional works at: https://digitalcommons.uri.edu/theses

\section{Recommended Citation}

Wray, Lisa B., "GUIDE PLAN FOR THE REDEVELOPMENT OF SLATERSVILLE, R.I." (1992). Open Access

Master's Theses. Paper 432.

https://digitalcommons.uri.edu/theses/432

This Thesis is brought to you for free and open access by DigitalCommons@URI. It has been accepted for inclusion in Open Access Master's Theses by an authorized administrator of DigitalCommons@URI. For more information, please contact digitalcommons-group@uri.edu. 


\section{GUIDE PLAN \\ FOR THE REDEVELOPMENT OF SLATERSVILLE, R.I.}

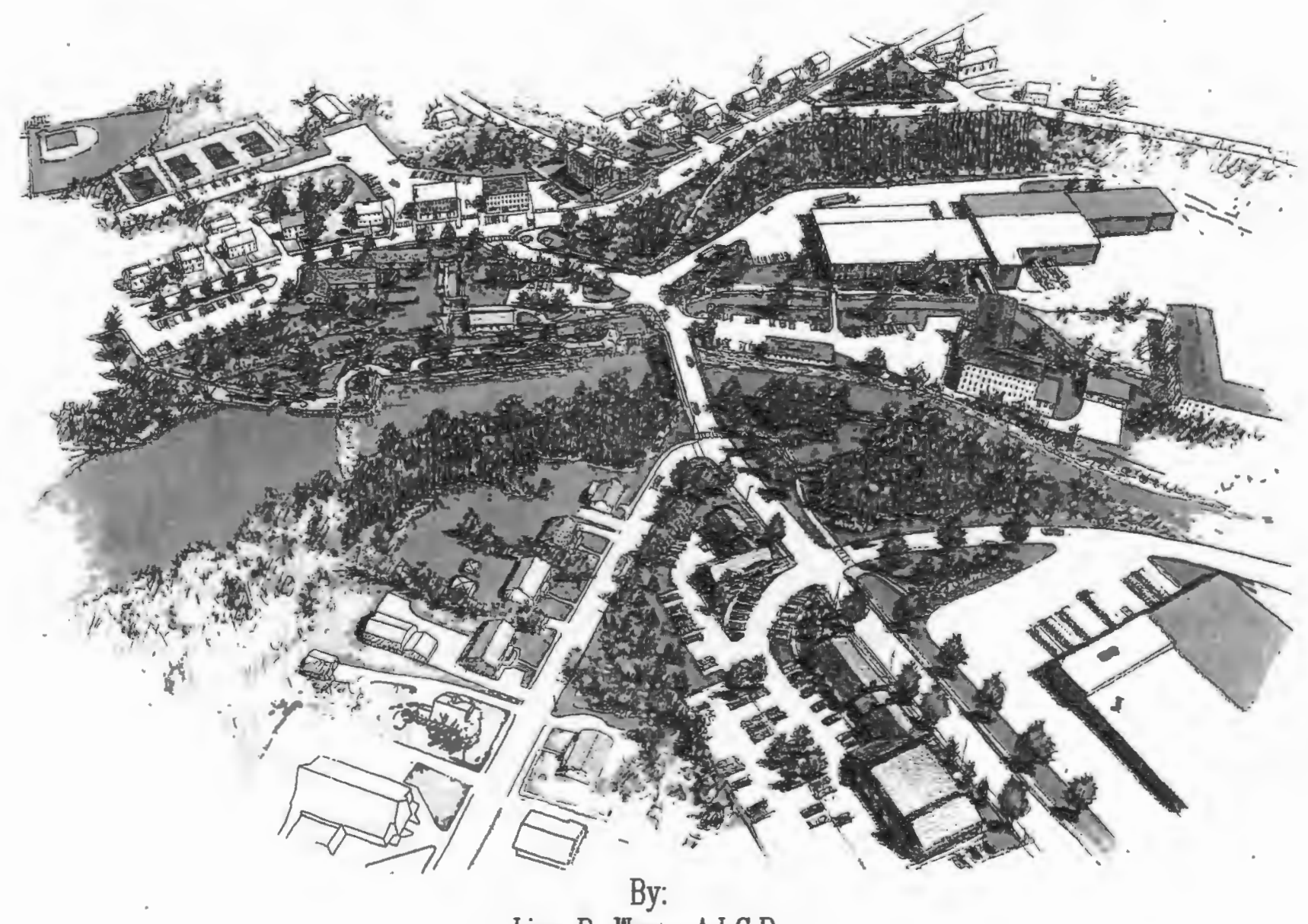

Lisa B. Wray, A.I.C.P.

A RESEARCH PROJECT SUBMITTED IN

PARTIAL FULFILLMENT OF THE REQUIREMENTS

FOR THE DEGREE AND MASTER OF

COMMUNITY PLANNING

UNIVERSITY OF RHODE ISLAND

1992 


\section{MASTER OF COMMUNITYY PLANNING RESEARCH PROJECT $\mathrm{OF}$ LISA B. WRAY, A.I.C.P.}

Approved: Major Professor twhad ol wh

Acknowledged: Ma cin Ma Mun to 
Acknowledgements

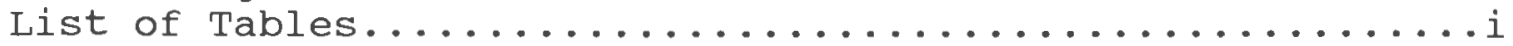

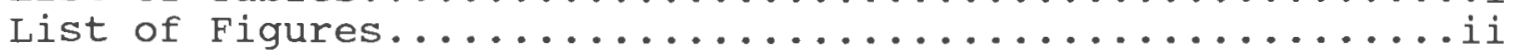

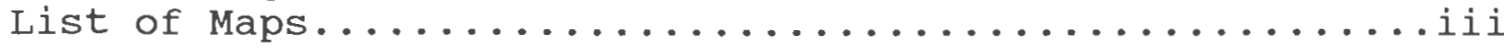

\section{Chapter}

\section{Part 1 - Background}

1. Introduction ............................

1.1 The Setting

1.2 Problem Focus

1.3 Planning Approach

1.4 Prominent Features of the Study Area

1.5 Redevelopment Trends and Review of Similar Studies

2. History of slatersville...................... 18

2.1 Development of Slatersville

2.2 Historical Buildings within the Study Area

2.3 The Significance of Historic District Designation to the Redevelopment of Slatersville

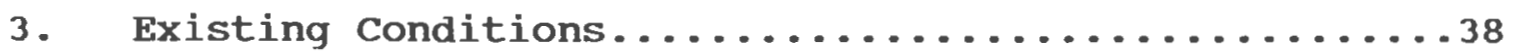

3.1 Existing Plans Relating to Slatersville

3.2 Building Inventory

3. 3 Zoning

3.4 Circulation

3.5 Infrastructure

3.6 Streetscape

3.7 Summary of Findings

\section{Part 2 - The Guide Plan}

4. Introduction to the Guide Plan................78 4.1 Guide Plan Development

4.2 Primary Issues Facing the study Area

5. Goals, Objectives, Proposals and Implementation

Strategies of the Guide Plan................83

5.1 Goals, Objectives and Proposals

5.2 Implementation strategies

6. Conclusion..................................

6.1 Summary of Findings

6.2 Conclusion 


\section{ACKNOWT.FDGEMENTS}

A very special thanks to Dr. Atash for seeing me through this process, in addition to Dr. Foster; you both gave me valuable feedback and guidance, in the nick of time.

Without the vision and expertise of the North Smithfield Town Planner, Karen Sherman, this project would not have been possible. Thank you for the opportunity Karen!

Diane williamson, your friendship and focus sessions were more help than you know. Thanks for your counsel, regardless of how busy you may have been.

other valuable contributors include the RI Historic Preservation Commission, The Northern Rhode Island Economic Development Partnership, Mr. Bourget of the North Smithfield Heritage Association and the Town of North Smithfield.

Barbara, you have been a great help, both financially and in the flexibility with which you allowed me to complete my degree.

A special thanks to Mom and Dad for listening to my Grad School turmoil long distance.

Jim, we made it. I love you and I couldn't have done it without you and the mutts. 


\section{TABLES}

\section{TABLE \# Description}

PAGE

3.1 Permitted Uses by Zoning District............53

3.2 Dimensional Regulations by Zoning District.......63

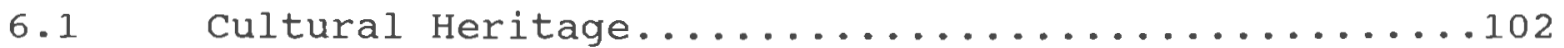

6.2 Significant Historical Resources..............104

6.3 Underutilized Recreation.......................

6.4 Economic Development Potential...............109

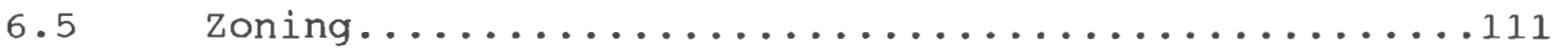

6.6 Constrained circulation................112

6.7 Infrastructure.........................

6.8 Poor streetscape.....................115 


\section{FIGURES}

2.1 Aerial Photograph of Mill Complex............. 24

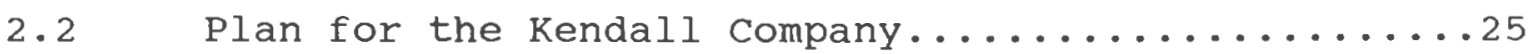

2.3 Old Photograph of Commercial Buildings............

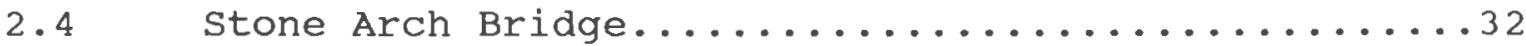

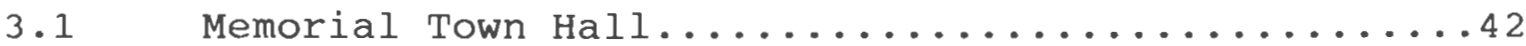

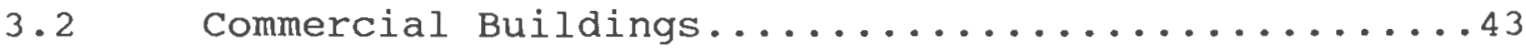

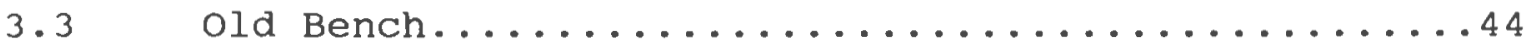

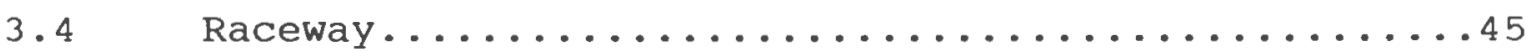

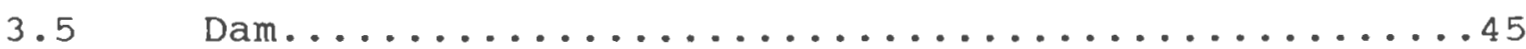

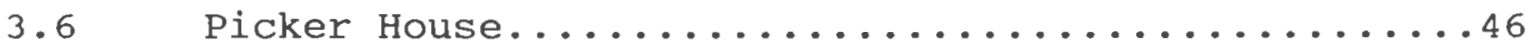

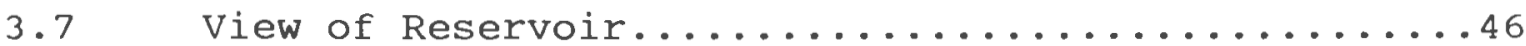

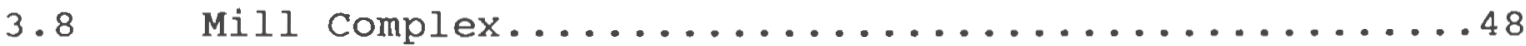

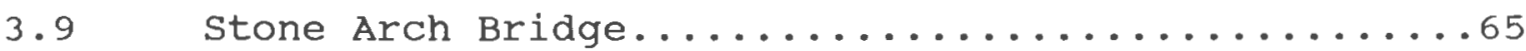

3.10 View Across stone Arch Bridge...............65

$3.11 \quad$ Parking.........................66

3.12 Sidewalk by Library ..................68

3.13 Sidewalk by Town Hall...................69

3.14 Sidewalk between Library and Post office.......69

3.15 Guardrail along Main street................70

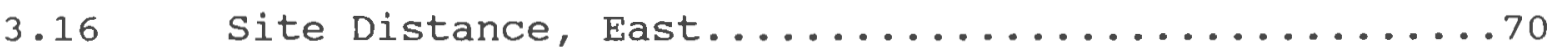

3.17 Site Distance, West.......................

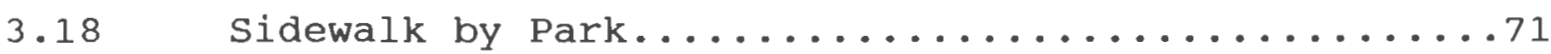

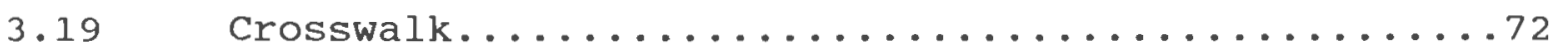

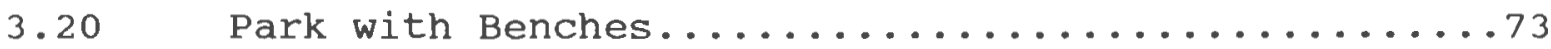


MAPS

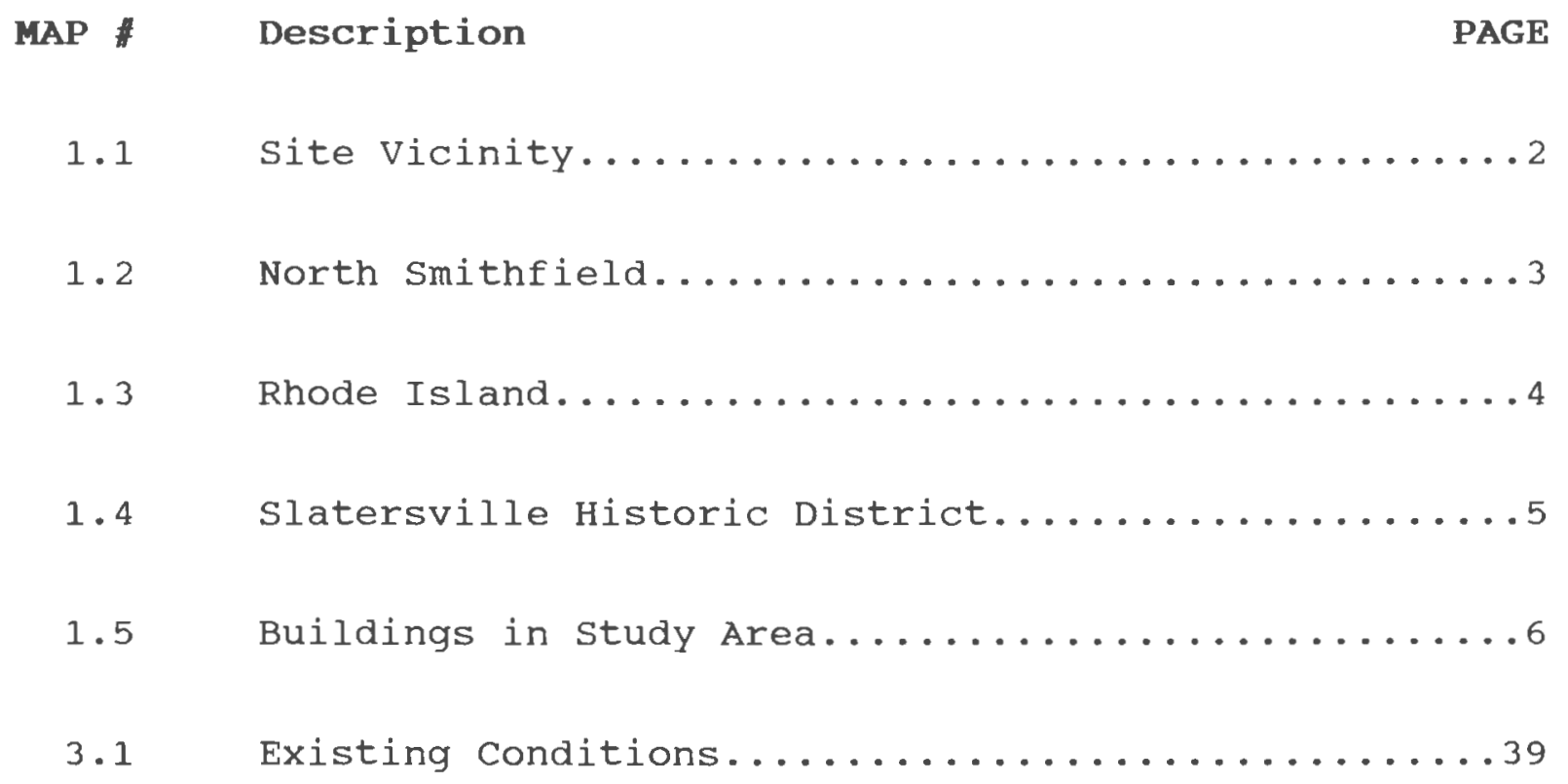




\section{CHAPTER I}

\section{INTRODUCTION}

\subsection{THE SETTING}

This report proposes to develop a Guide Plan for the Redevelopment of Slatersville, R.I. (Map 1.1). Slatersville, once a self-sufficient, planned village, is the heart of the Town of North Smithfield (Map 1.2), in Providence County, R.I. (Map 1.3) Slatersville, formerly a mill village and company town remains an intact historic village. It was planned around the Branch River, which was used for water power to run the mill. Slatersville has many historic structures, including the mill complex and the village of slatersville is listed as a National and state historic District. The slatersville Historic District ${ }^{1}$, is located within the Federally designated Blackstone River Valley National Heritage Corridor. The Slatersville Historic District, established at state and National levels in 1973, has been identified by both the Town, in its most recent Comprehensive Plan, and the Blackstone Valley National Heritage Corridor Guide Plan as an area in need of an integrated Plan encompassing the area central to the Historic District (Map 1.4). The study area includes the slatersville Mill complex, the Town Hall, two commercial buildings and the Library Association's Centennial Park (Map 1.5).

1 The Slatersville Historic District includes the slatersville reservoir, dams and water power systems, and 19th century mill, commercial blocks, mill houses, churches, and other buildings along Main street, Green street, School street, Railroad Street and several side streets. 


\section{MAP 1.1}

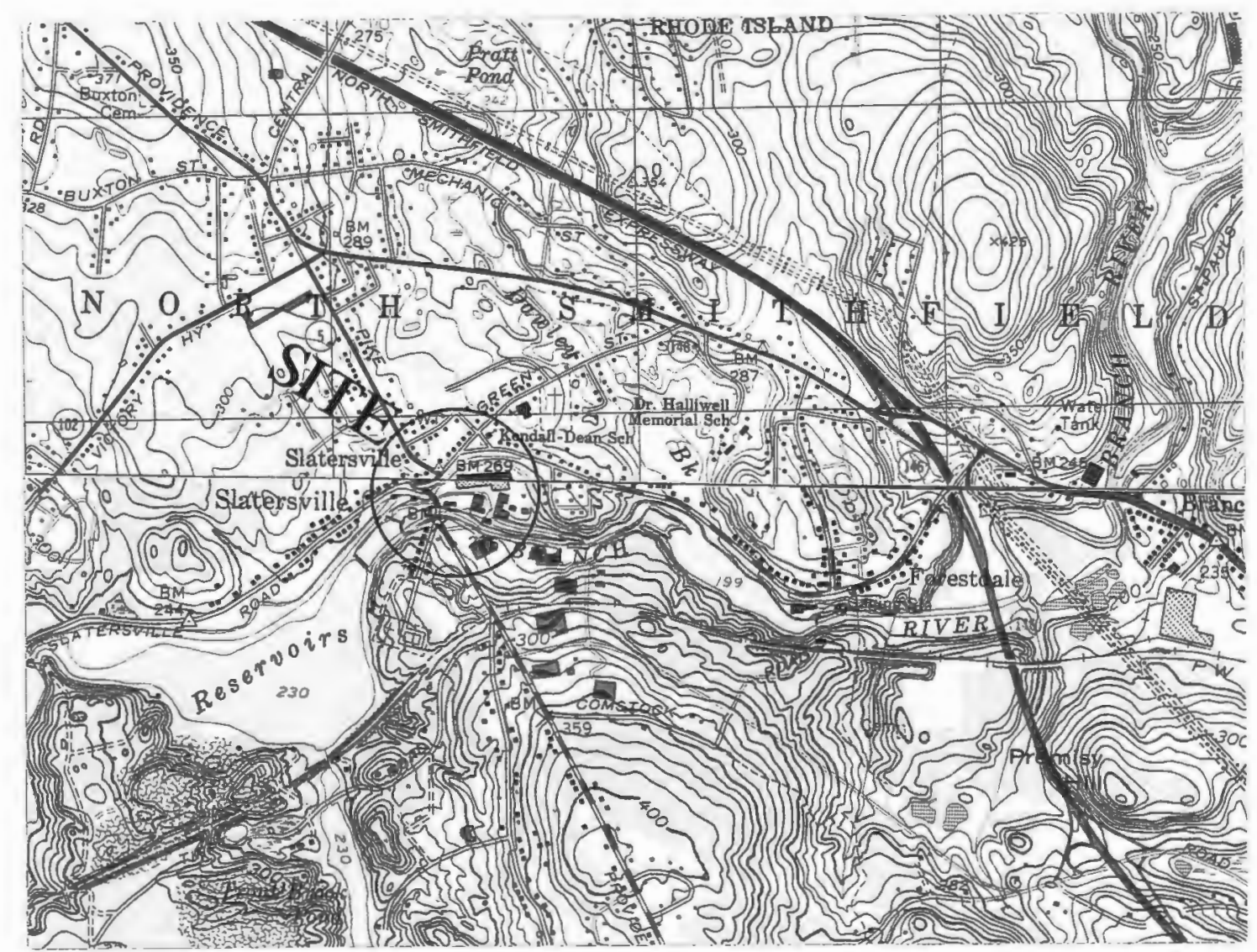

GUIDE PLAN

FOR THE REDEVELOPMENT OF SLATERSVILLE

\section{SITE VICINITY MAP}

\section{SCALE 1:24,000}

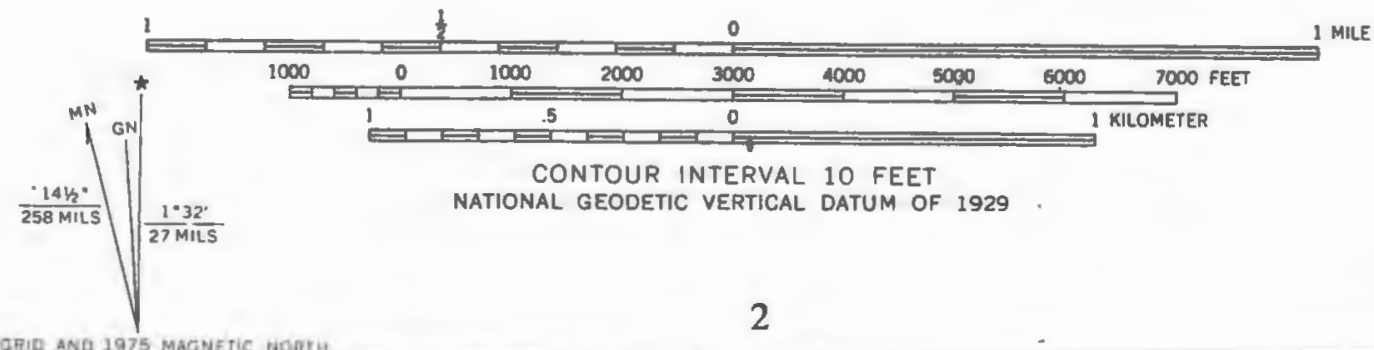




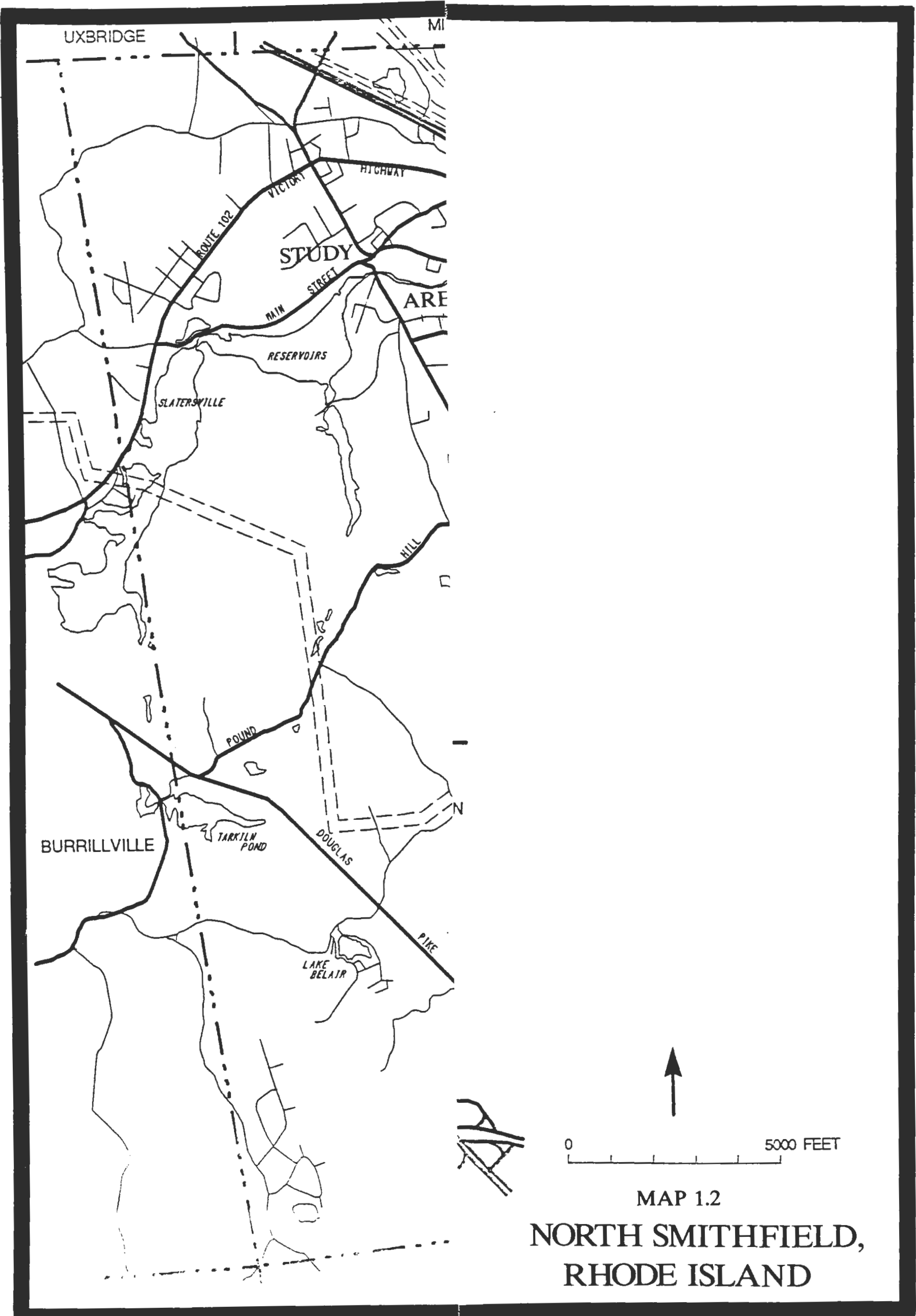




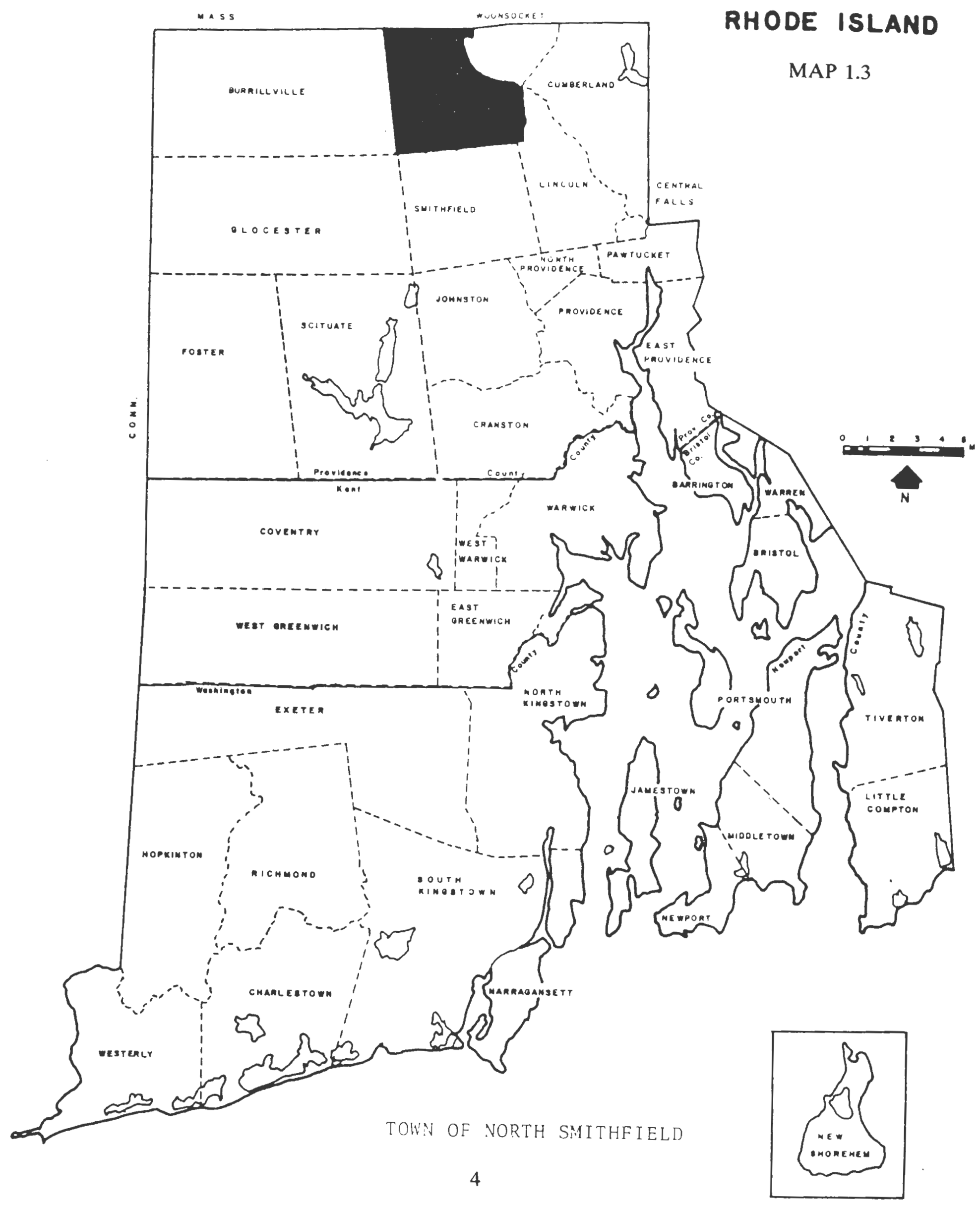




\section{SLATERSVILLE HISTORIC DISTRICT}

NORTH SMITHFIELD, RHODE ISLAND

HISTORIC DISTRICT COMMISSION

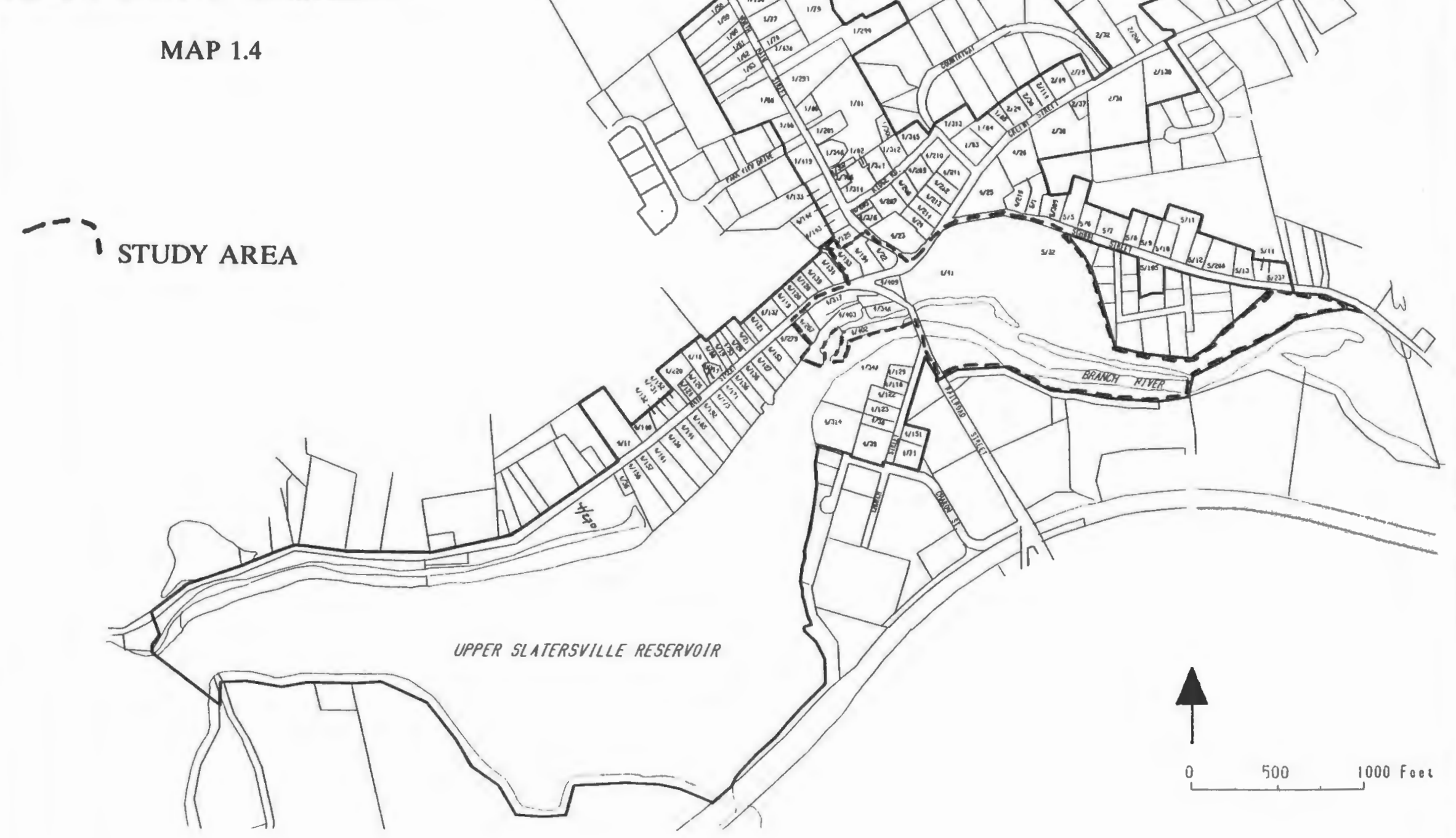




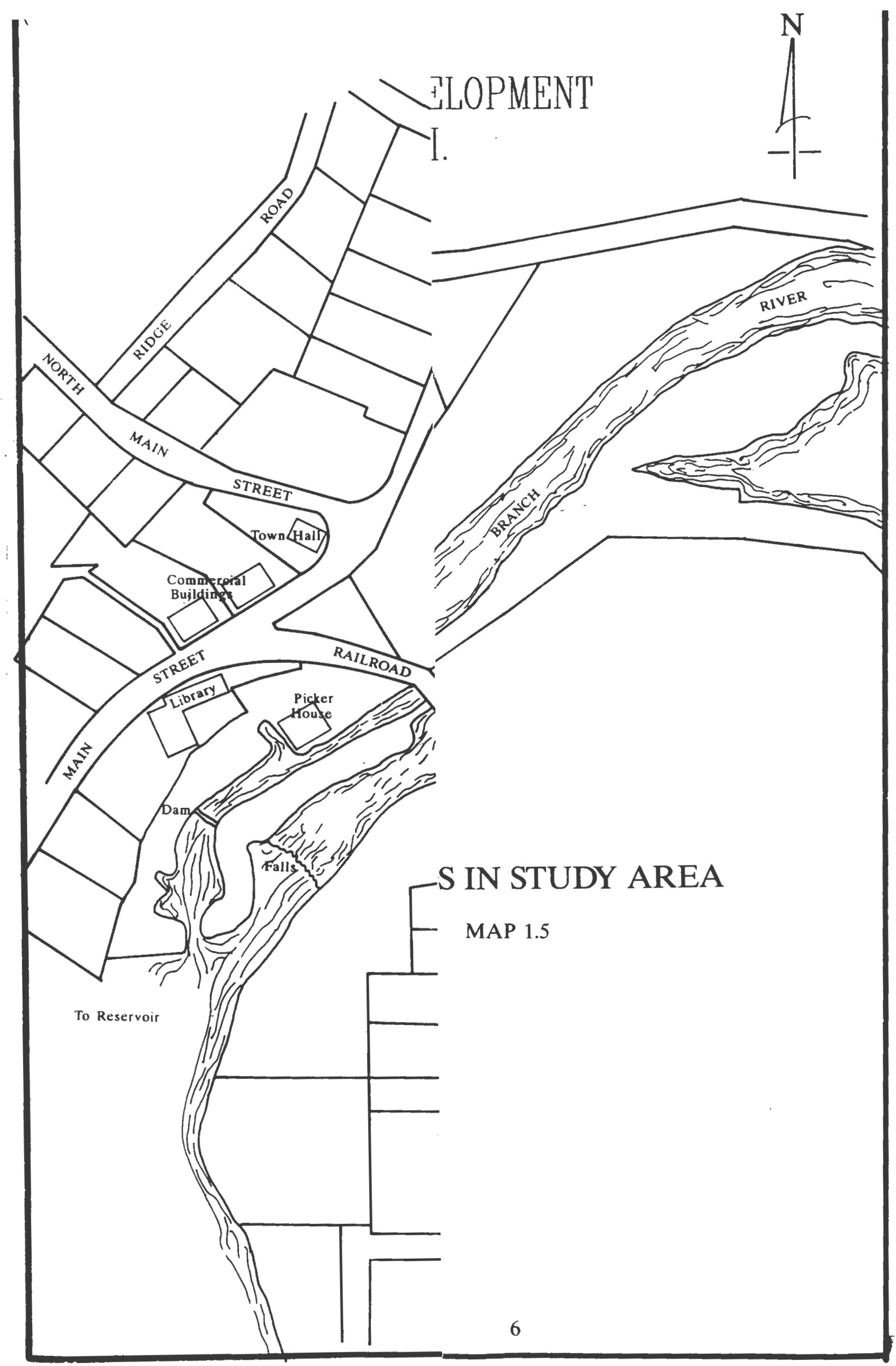


The Historic District, developed as a company town, was once vibrant; where the needs (general store, bank, etc.) of the population surrounding the mill were served by the central business district. With the decline for the need of mill operations, and increased industrial stagnation, due in part to the strip commercial development of the norther edge of the district, this area has fallen to underutilization. The study has been identified as a potential source of economic development, recreation, tourism and historic preservation.2

\subsection{PROBLEM FOCUS}

Without an overall layout and plan for the study area, redevelopment would occur incrementally which would be a detriment to the preservation and integrity of the slatersville Historic District. The Guide Plan presented in this report, while drawing on the existing resources and site features, will develop goals, objectives, and proposals in addition to strategies for implementation. This will provide a vital planning document for decision makers which will guide in slatersvilles' redevelopment. The Guide Plan make an attempt to balance economic revitalization with historic preservation. The plan provides both the Town and private enterprise with the necessary tools to protect the integrity of the area and to integrate new, compatible development commensurate with existing national, state and local

2 North Smithfield Comprehensive Plan. Burk Ketcham and Associates. 1991. 
goals for the area.

In a study conducted by George Daniel Meservey, III, the former Slatersville Mill site was ranked as the best overall for adaptive re-use of all the mills studied within the Blackstone River Valley.

The creation of a Guide Plan for the redevelopment of the former slatersville Mill and the surrounding area furthers the goals and purposes of the Blackstone River Valley National Heritage Corridor, in which it is located. The goals and purposes of the Corridor are set forth in the State Guide Plan Element 131, Cultural Heritage and Land Management Plan for the Blackstone River Valley, National Heritage Corridor.

As stated in the State Guide Plan Element 131, protecting and enhancing the National Heritage Corridor can be successfully achieved by combining the resources of both public and private enterprise. This project has been foreseen through meetings by a public/private partnership consisting of the Town of North Smithfield, the North Smithfield Library Association and Polytop Corporation (potential purchaser of the slatersville Mill site). Therefore this project will meet the objectives of the cultural Heritage and Land Management Plan for the Blackstone River Valley, National Heritage Corridor, State Guide Plan Element 131. This State Guide Plan Element has been thoroughly endorsed within the North Smithfield Comprehensive Plan.

Within the Implementation Element of the North Smithfield Comprehensive Plan, the Town has outlined a program to prioritize 
implementation strategies for achieving the stated goals of both the Town and the Corridor commission. Within this program, the Town has given a project such as this proposed Guide Plan a high priority as a "special study to be conducted which would encompass the adaptive re-use of the Mill site and support of the preservation goals of the Blackstone River Valley National Heritage Corridor" .

The key players, which form the public/private partnership are described below along with their "stake" in the Plan. The North Smithfield Library Association is a non-profit organization independent of the Town. The Library Trustees are interested in re-developing the Centennial Park for passive recreation. The area has been underutilized and poorly maintained in the past several decades. Preliminary meetings have been held with the Library Trustees and Town officials to work on a plan for rehabilitation and maintenance. Polytop Corporation, a private manufacturing firm located on the south side of the Branch River across from the site, is negotiating the purchase of the former Slatersville Mill property, and has signed an option agreement with the seller. In anticipation of this purchase, polytop has entered into discussions with the Town of North Smithfield regarding the re-use of the site. 


\subsection{PLANNING APPROACH}

Data Collection and Research - The background research includes historic research as well as on site investigation. An essential part of the background research will include an overview of other historic district studies, chiefly, mill renovation/rehabilitation projects. In addition, meetings with one or many of the key players in the process are necessary; such as Town officials, the Town Planner, members of the North Smithfield Library Association, site owners and/or interested buyers, members of the Town of North Smithfield's Historic District Commission and Heritage Association of North Smithfield, members of the Blackstone River Valley National Heritage Corridor Commission, and members of other appropriate local, state and regional agencies. It is from this process that the existing conditions, and major issues facing the study area will be ascertained.

once the major issues facing the study area are identified, goals, objectives and proposals will be recommended. These recommendations will lead to strategies for implementation and a final conclusion.

Final Report - The final product of this study will be a written "Guide Plan" comprised of the goals, objectives, proposals and implementation strategies for the redevelopment of slatersville.

This project will serve as an initial planning document to guide redevelopment in central slatersville. More comprehensive 
or site specific studies will be necessary to more accurately define the most appropriate uses for the myriad of buildings at the Slatersville Mill Complex. This Guide Plan will create a planning document which includes not only goals and objectives but proposals which link the spacial relationships between structures and features within the village as well. This will include such elements as proposed site improvements, and proposed projects for implementation.

\subsection{PROMINENT FEATURES OF THE STUDY AREA}

To understand the scope of the study, it is necessary to define the physical elements being examined. These elements include, as stated earlier, the Slatersville Mill Complex, the Commercial Block, the Town Hall, Memorial Hall, and the Library Associations' Centennial Park.

The Slatersville Mill Complex has been vacant since 1991 when Glas-Kraft (a company specializing in manufacturing of laminated and glass fiver reinforced papers for the packaging, agricultural and construction fields) shut its doors. Glas-Kraft utilized primarily the brick manufacturing facility (formerly the Weaving Building). This mill complex is dominated by a large four story mill, built in 1826, to replace a mill built in 1806, which was destroyed by fire. Prior to that time, the mill complex had a long and distinguished history, including being the first textile mill village in Rhode Island, which is believed to be the first in the nation. It should be noted that the 
Slatersville Mill Complex was ranked number one for re-use potential in a study of mills along the Blackstone River Valley. ${ }^{3}$

The Town Hall (Memorial Town Building) is presently being used at full capacity and additional space has been noted as a goal in the most recent Comprehensive Plan (October 1991). The possibility of this building being vacated completely by the Town for a building with more space is very feasible. Therefore reuse plans are essential.

The two commercial buildings are partially occupied at the present time but are underutilized. The first commercial building is owned by Fleet Bank, who is the only tenant of the building. Parking for this building is minimal. The second commercial building has several small businesses and has three floors which are finished for business occupancy. The current owner of record is listed as Richard Gallant, RHG Realty.

The Library Associations' Centennial Park consists of property behind the Library and adjacent to the reservoir. This property was the site of the West Mill Complex and includes a small ( $1 / 3$ acre) island, a deteriorating building and remnants of the old water works from the mill operations. The Library (whose building was also part of the original West Mill Complex) has contracted a preliminary landscape design for the property and they await this study to tie the park in the surrounding area.

Mill Preservation in the Blackstone River Valley. A Research Project, CPAD, URI. 1992. George Daniel Meservey, III. 


\subsection{REDEVELOPMENT TRENDS AND REVIEW OF SIMILAR STUDIES}

During the past three decades, the historic preservation movement has grown from a small group of history-minded preservationists to a large popular movement with a wide and varied constituency. ${ }^{4}$ Growing interest in history and in preservation of the built environment has led to increased awareness of the value of old buildings and historic areas. The historic value of slatersville has been recognized on National and state levels and has the potential to become a local historic district subject to the North Smithfield Historic District Commission Regulations. This trend in historic preservation spreads country wide as varied historic areas are preserved through adaptive use, such as waterfront districts, individual historic buildings, and old mill villages.

Adaptive use is the process by which structurally sound older buildings are redeveloped for economically viable new uses. Such buildings may be historically important, architecturally distinctive, or simply underutilized structures which exhibit signs of life under a facade of age and neglect. ${ }^{5}$ This is distinguished from restoration and renovation by the following definitions:

Restoration - refurbish a building's original architecture details as closely as possible.

4 Adaptive Use. Urban Land Institute. 1980

5 Ibid 
Renovation - Physical upgrading of materials and support systems while retaining a building's original use. ${ }^{6}$

Real estate developers are sometimes finding rehabilitation of historic buildings an attractive option for a myriad of reasons. The increasing requirements to consider social, economic, and environmental consequences of proposed new construction on the surrounding area can add further "costs" to the development process; creating a special interest in the adaptive use of existing buildings. Strong reuse potential has been recognized in buildings which have distinctive physical and locational characteristics.?

Adaptive use has become a mutual interest to those groups concerned with the preservation of our cultural, historic, and architectural heritage, and to the real estate investment community striving to widen development opportunities.

Examples of adaptive use of historic structures are numerous. For the purpose of this study, this section will focus on projects which are similar in character to the study area. Since slatersville is unique in its character, exact examples are not possible. However, it is a goal of the North Smithfield Comprehensive Plan to redevelop the mill complex for mixed use. The mill complex was originally the center of focus for slatersville, and could be again. In addition, the mill complex is the currently the most underutilized space in the study area.

6 Ibid
, Ibid


Therefore, this section will focus on adaptive use projects which were redeveloped for mixed use in old mill or similar type buildings.

1.5.1 Contoocook Mills Industrial District

This Mill Complex is located in Hillsboro, New Hampshire and is listed on the National Register of Historic Places. This Mill Complex, whose origin dates back to the mid 1800's, was converted to Apartments, offices, and commercial space in 1972. Two brick structures in this six-building are undergoing conversion to commercial and office use. Redevelopment of the $3 / 4$ acre complex, located in downtown Hillsboro, has received general support from the community but encountered resistance from local politicians and lending institutions. The developers, who paid $\$ 2,500$ for the mill buildings, secured a loan from a savings bank out of town. ${ }^{8}$

\subsubsection{Palmer Square, Princeton, New Jersey}

Palmer Square is a mixed-use town center with 143,600 square feet of office; 85,500 square feet of retail; a 217-room hotel; 124 existing and 97 future residential condominiums; and two parking structures. Development began in 1935 around a central green and was reinitiated in 1981 with a variety of renovation, infill, and expansion projects. The project is cited often as a neotraditional town center prototype. 9

$8 \quad$ Ibid

- Urban Land Institute, Project Reference File. Volume 20, Number 20. October-December, 1990. 


\subsubsection{Warehouse Row, Chattanooga, Tennessee}

This project is located in the heart of the traditional business district. A 323,000 square-foot mixed-use complex containing three levels of specialty retail and three levels of Class A office space. The retail tenants are high-end manufacturers direct outlets. The downtown project involved restoration and expansion of eight historic warehouses, construction of a 450-space parking garage, and creation of a one-acre public park. ${ }^{10}$

\subsubsection{The Kaiser Mill Complex, Bristol, Rhode Island}

The Bristol Mill Complex was constructed in 1860 , for the purpose of manufacturing rubber goods. Although the Mill Complex is not fully developed, the owners have worked closely with the community, the town and professionals to design a plan which is endorsed by the neighborhood. This plan incorporates retail, service, and mixed-use housing, (including the disabled, the elderly, and families-without children). An important element in this project is the existence of a local development organization that had the experience and ability to secure financing. The Bristol Foundation is a non-profit organization which makes it eligible for Federal Assistance, (HUD, section 202). ${ }^{11}$

1o The Urban Land Institute, Project Reference File. Volume 20, Number 6. April-June 1990.

11 Bristol, R.I. The Kaiser Mill Complex: Reuse and Restoration. Informational Brochure by the R.I. Division of Planning. 


\subsubsection{Queechee Village, Vermont}

Queechee Village developed historically around a central

mill, powered by water from the ottoqueechee River. Today, Queechee is a planned community, with central amenities such as a ski mountain, a golf course and a club house. The mill is used today for commercial uses; retail pottery store and restaurant, overlooking the water fall. Glassware is blown on premises using hydroelectric power, which is open to patron viewing. The village is similar to slatersville in size, is surrounded by residential area, and is bisected by 2 main roads; one traversing a covered bridge which serves as a village entrance.

Although the mill is significantly smaller than the Slatersville Mill Complex, the surrounding area more closely resembles slatersville than any of the other discussed rehabilitation/reuse projects. 


\section{CHAPTER 2 \\ HISTORY OF SIATERSVIIIE:}

This Chapter will address historical considerations relating to slatersville. These include the history of slatersville as well as the specific historic structures which are located within the study area. In addition, slatersville is designated as a National and State Historic District, which includes the study area. The significance of this designation will be addressed as well as the implications of local Historic District designation.

\subsection{DEVELOPMENT OF SLATERSVILLE}

Slatersville began as a small settlement, known as Buffam's Mill, supporting a grist mill and saw mill and surrounded by dense forsst and tangled swamp. This sawmill, once at the location of the present stone mill, was in operation in 1805 with a wool carding machine on the upper floor. "During this time, before the cotton could be carded and spun in the mill it must first be picked over by hand. This was done in the neighboring farmhouses at a cost of from $5-6$ cents a pound. After the thread was spun, it was sent among the wives and daughters of the countryside to be woven with hand looms. It is told that the houses of the early day were built with cellar kitchens that by this arrangement might be secured rooms which by reason of dampness should prove more favorable for weaving. This was the 
old fashioned humidifying method."12 These primitive arrangements were continued until about 1820 when additions were made to the mill plant and a new era was begun.

Samuel slater, who built the first American cotton mill at Pawtucket, was joined by his younger brother John in 1803, and together they explored areas around the Blackstone River that would provide the requisite resources for a new textile mill. In addition to the necessary water supply, they hoped to discover a rural area where farm families could supply dependable labor in the mills, and where moral values would be highly regarded. A few miles up the Branch River, a tributary of the Blackstone, they believed that they had found such a place, and in 1806 Slatersville was established. ${ }^{13}$

The water power in this area was recognized as a valuable water privilege and was secured for the enterprise which the slaters started here with the assistance of William Almy and Obadiah Brown (Almy \& Brown), the Providence merchants who were responsible for the financing of the original cotton mill at Pawtucket. Early in the history of the business, the slaters purchased the Almy and Brown interest in the mills and the Slater family control was maintained until the early $1900^{\prime} \mathrm{s}$.

The first mill in slatersville, mostly of stone, was completed and ready for service on July 4, 1805, on which day the

12 Evening Bulletin, (Providence), Saturday, March 30 , 1930. The week in RI Mills and Factories section.

13 North Smithfield Centennial - 1666 to 1971 
water was turned on and spinning began. Growth was rapid. A store opened in 1806 and tenements were constructed. The following year saw the erection of the meeting house for both religious and secular use, paid for by the proceeds of a lottery $\cdot^{14}$

Growth continued and cart paths turned into streets - Greene Street, Main Street, Back (North Main) Street, and Railroad Street (Providence Pike) - and the whole area filled with houses and mill buildings. The bank opened in 1818 as the Burrillville Agricultural and Manufacturers Bank, four years later was renamed the Village Bank, and then in 1865 became the Smithfield National Bank, which it remained until its absorption into the Industrial National Bank in the 1970's. Fleet National Bank, formerly Industrial National Bank, still exists in this location today. The Village name became official with the establishment of the post office in 1817. Construction started on what came to be known as the Western Mills in 1821, and this complex was enlarged subsequently on three occasions until by 1894 it included eight buildings.

Exemplifying the typical mill village pattern of growth and development, the simple mill workers' houses were built near the mill; the supervisors' houses were established along the green, or common; and the owner's house was a fine residence set on a large lot, physically separated from the other houses. A "Yankee" community for much of the century, a profound change was

$14 \quad$ Ibid 
effected after the civil war by the influx of large numbers of French-Canadians who came to work in the mills.

As Slatersville grew, it became the social center of the area. Though the cause of "temperance" was strong throughout the nineteenth century and the slaters prohibited the sale of liquor in the village area, several inns and taverns just outside the village were popular, and no house or barn anywhere - excepting the church - was raised unless a keg or two of rum was provided. The first brass band in the village began around 1841 and was especially in demand for the grand Forth of July picnics held in nearby groves along the river. For the better-educated there was the lyceum group which met frequently in the 1830's to discuss matters of weighty import. In 1840 the Slaters and Amos Lockwood founded a library which was subsequently located in the bank building. This facility was well stocked and gave useful service for more than half a century.

In 1900, James R. Hooper, a Boston banker, purchased the mills and village. The Mill Complex then became known as Slatersville Finishing Company. The slatersville Finishing Company used the pure and soft water of the Branch River to bleach, mercerize, and dye cotton cloth. A street car line and a railroad servicing the village combined with the transformation of the mill, resulted in some village residents seeking employment outside slatersville for the first time.

In 1915, the plant was acquired by the Kendall Mills, Inc. and was still known as the Slatersville Finishing Company. 
Kendall Mills, Inc., a Massachusetts Corporation with a main office in Boston, was one of the largest manufacturers of hospital supplies in the United States. Kendall's other mills were located at Walpole MA, Edgefield and Newbury S.C., Chicago Illinois, and Paw Creek N.C. In 1915, Henry P. Kendall purchased Slatersville, and, with his manager, Arthur Beane, modified the appearance of the village to more closely reflect his idealized conception of a New England Village. He planted trees, moved buildings, and modified the mill houses to make them more individualistic and "private" looking. In 1921, a town hall was built in the center of slatersville, and a consolidated school was built in the $1930^{\prime} \mathrm{s}$. Although, under Henry Kendall the slatersville mills continued manufacturing textiles, Kendall, like many other New England mill owners, transferred his operation to the south in 1956. About this time, the company also sold its ownership in the village and slatersville ceased to be a company town; for the first time in some 150 years, houses and other buildings became individually owned, most of the residences acquired by their occupants.

Glas-Kraft purchased the old slatersville mills in 1959 and began the manufacture of asphalt-laminated, glass-fiber reinforced paper. They continued this operation until 1991.

\subsection{HISTORICAL BUILDINGS WITHIN THE STUDY AREA}

The buildings within the study area have been placed within a National and State Historic District because of their 
historical significance. Each building has been inventoried by the State Historic Preservation Commission. This documentation, as well as other available historic information, has been compiled and is presented within this section.

\subsubsection{Slatersville Mill Complex}

The Slatersville Mill is a privately-owned mill complex which is listed on the National Register of Historic Places. It is improved with the following buildings and associated structures which were originally used for the slatersville Finishing Company and later The Kendall Company: an office building, two (2) mills; a "weaving building" which, until recently, housed the manufacturing activities of Glas-Kraft, Inc.; a powerhouse with a smokestack; garage; reservoir building and a gatehouse, as well as a raceway which moves water through the site. The old aerial photograph (Figure 2.1) was taken while the Kendall Mills owned the Mill Complex. Its orientation is north-east where the Branch River is in the foreground. In addition, an old plan for the Kendall Company (Figure 2.2) was found in the files of the N. Smithfield Heritage Society files. It scematically depicts the location of each building as well as its location within the study area sometime in the early 1900's. The site is serviced by municipal sewer. Process water and water for fire fighting has traditionally been taken from the canal of the Branch River. Well water is utilized for the wash basins and drinking. 


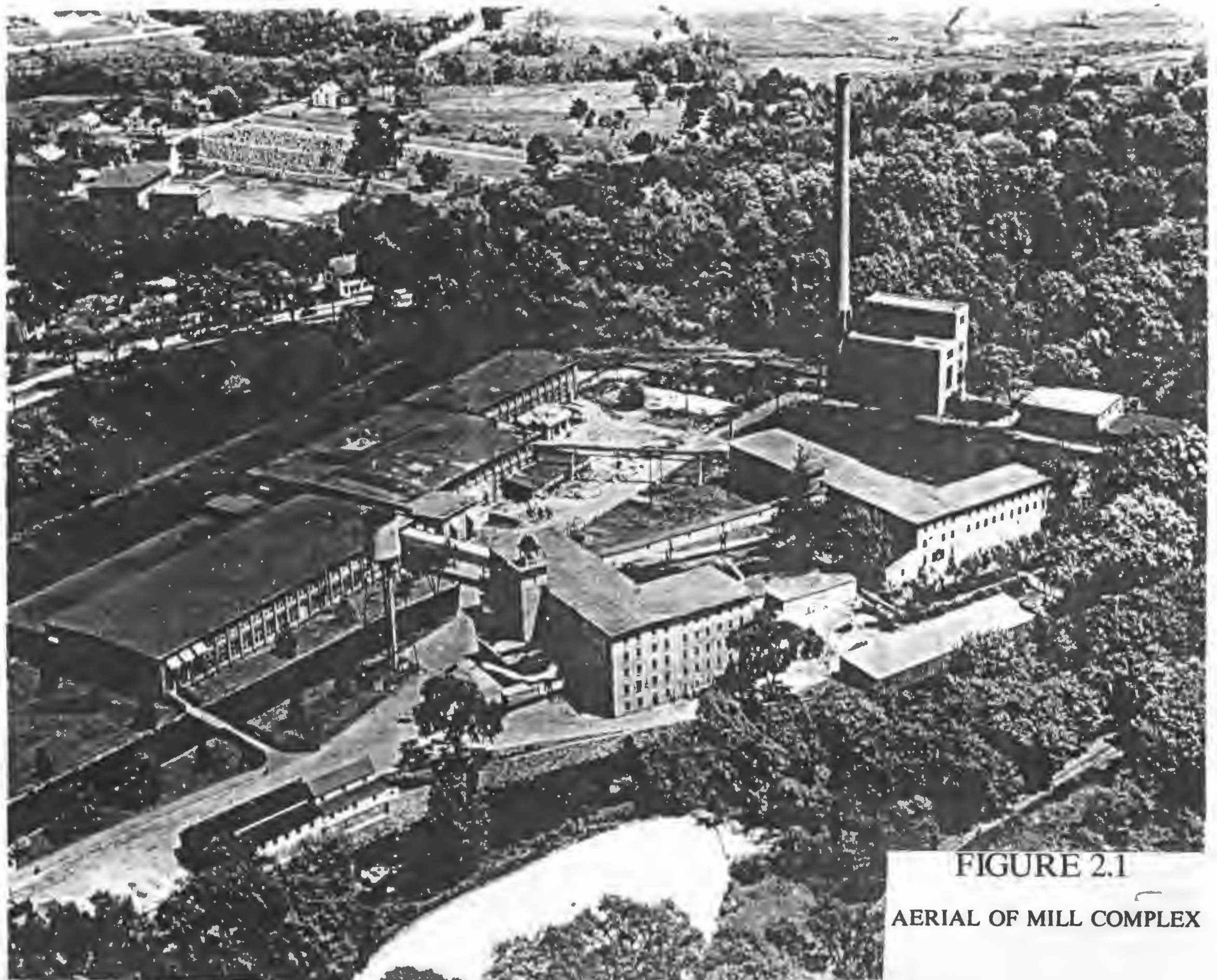

ก 


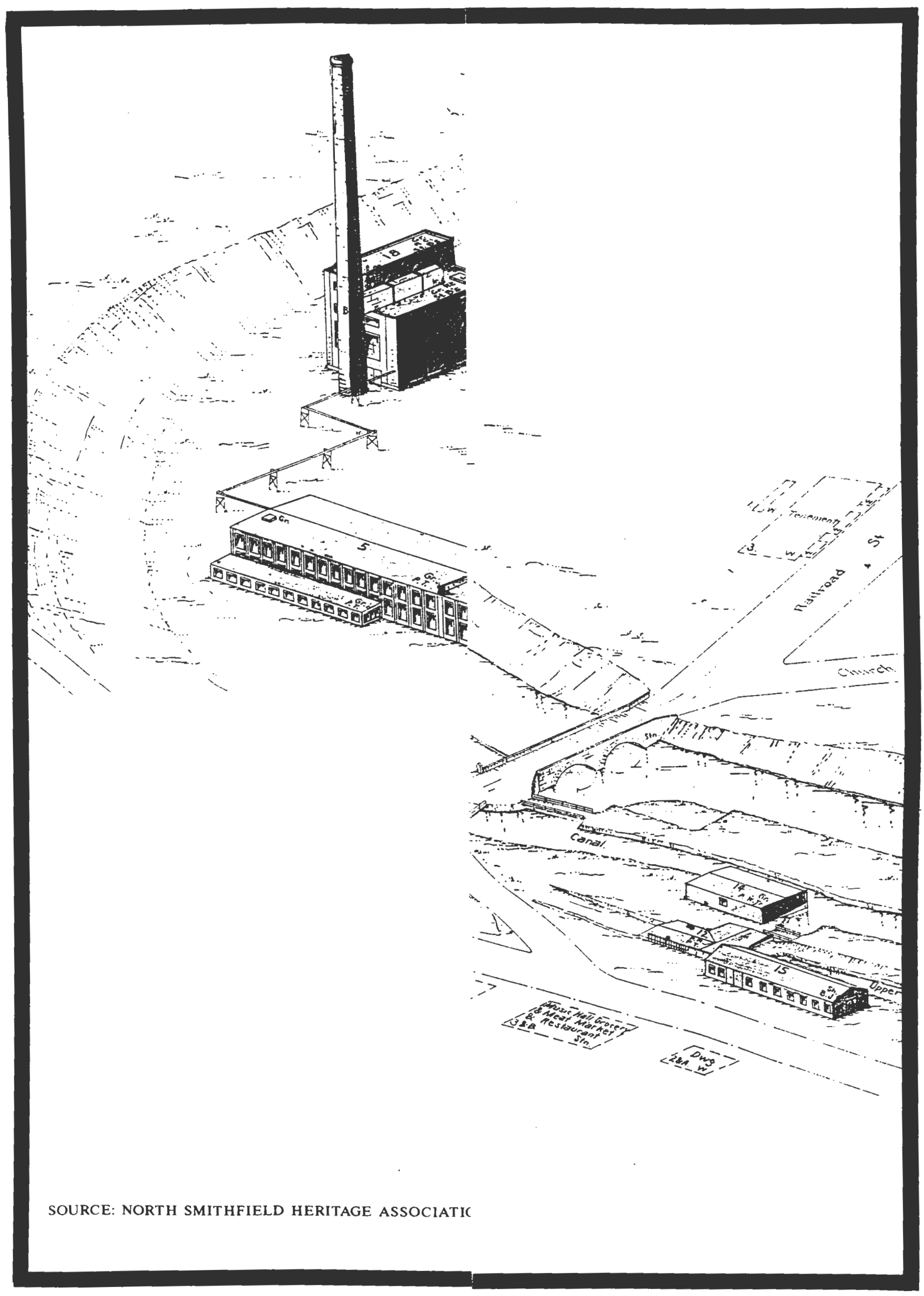


The office Building

The office building is a one and a half story, wood-frame building, covered with white-painted wooded clapboards and situated on the western edge of the mill complex near Railroad Street (also known as Route 3, or Providence Pike), which is believed to be the oldest mill-related building in slatersville and probably was built in 1806 or 1807 . The structure is capped with an asphalt shingle-covered gable roof which features a trapdoor monitor. Windows are of the one-over-one and six-over-six wood sash variety and are set in rectangular surrounds. It served as an office building since at least 1894 , perhaps even back as far as 1807. Inside the building has undergone much alteration and until recently it housed the offices for the Glas-Kraft Manufacturing Company .

The slater No. 1 Mill Building

The slater No. 1 Mill building is a westward-facing, five-story stone structure which is located approximately 200 feet west of the office building. It was constructed in 1826 on or near the site of the original slater Mill which had burned earlier that year. Because the structure was erected on the edge of a small hill in order to provide the dampness and humidity needed on the first floor for the proper handling of cotton, it appears, when viewed along its front (west facade), to be a four story building. The heavy, native stone walls of this L-shaped structure rests on foundations of the same material, and the building is capped with a slightly-pitched, asphalt-covered gable 
roof which has an overhanging plain wood cornice featuring carved wooded brackets. Originally, this building had a steeply pitched gable roof, but around 1900 it was replaced by the present one. This building is currently vacant and in need of repair.

The most notable exterior features are single, squareshaped, projecting entrance towers which are centrally located on the front and rear facades. Both are constructed of stone, rise to a height of five stories, and are capped with flat roofs with overhanging bracketed wood cornices. The tower on the front facade, however, is capped with an arcaded belfry with its bell still intact. Originally this belfry featured a tall narrow spire, but it was removed when the roof was altered. Windows and doors are set in rectangular surrounds, and windows, for the most part, are of the 12-over-12 wood sash variety.

Connected to the building is an L-shaped addition which is a two story and appears to be of mid-19th-century vintage. Approximately 30 feet east of the mill is a 19 th-century gas house which has been converted into a garage. Originally, there were several structures at the rear of the edifice, but these have been demolished.

The slater No. 3 Mill Building

The slater No. $3 \mathrm{Mill}$ is located approximately 200 feet east of the No. $1 \mathrm{mill}$. This is a four-story stone building constructed in 1843. A portion of the wheel house and water power equipment, situated at the southwest corner, is still in tact. This building had been used for storage space, however, it 
is currently vacant and in need of repair. The structural integrity of the building has not been determined and visible deterioration includes cracked walls and foundation and poor roof quality.

The Weaving Building

The Weaving Building is a two-story brick building located approximately 100 feet north of the mill buildings and separated from them by the raceway. It was originally constructed in 1894 (parts of the building were added in later years) along the mill trench and was used as the bleachery building for the Kendall Company which ran the finishing mill. Early surveys of the site from the 1930's indicate that the following operations were conducted in this building when it was utilized as a textile operation: bleach house, for starching, drying and bleaching; dye house, for dyeing and mercerizing; caustic room; drug room; mixing room; office; dye house laboratory; general laboratory; and "kier" house. Until recently, this building housed the manufacturing activities of Glas-Kraft, Inc. which owned the site from 1959 until 1992.

\section{other Mill structures}

The garage and power house located within the mill complex have been utilized for storage purposes. The garage, which is located approximately 30 feet east of the No. I Mill building was a 19th century gas house which had been converted. The well is located in a small, brown, wooden shed to the east of the No. 1 Mill building. 


\subsubsection{Western Mill Complex}

The Western Mill Complex is the former name of the mill which was located to the west, across Railroad street from the slatersville Mill Complex. This mill complex is also partially shown on the previously shown plan for The Kendall Company. Towards the end of the century, these mills were closed, and sometime after 1900 the entire complex, with the exception of two buildings was demolished. This complex currently encompasses the present North Smithfield Public Library and to the south of the library building along the Branch River is the North Smithfield Library Association's Centennial Park. Within the park area, one building from the complex still exists but is deteriorating; this is known as the Picker House. This is a one-story stone edifice capped with a low-pitched, tar-covered gable roof and featuring a plain overhanging wooded cornice. Windows and doors are set in rectangular surrounds, but the six-over-six wood sash windows which were original to the building have been removed and window openings blocked up. The construction date of this building is unknown, but it probably dates from the 1860-70 era. Its most recent use was a foundry. The buildings has sat vacant for some time and its structural integrity has not been officially determined. Visual analysis shows the building to be in extremely poor conditions with one wall (towards the raceway) partially crumbled and the roof in need of repair.

\subsubsection{Town Hall}

Town Hall was built in 1920 and is located at the corner of 
Greene street and North Main. The brick neo-Georgian structure was built on the site of a long established hotel and boarding house. The building achieves a measure of dignity by virtue of its colossal pedimented porch and its situation atop high ground.

\subsubsection{Commercial Buildings}

The twin commercial blocks on Main street were erected by the mill owners in 1850 and 1870. Each is three-and-a-half stories, of stone-rubble construction, with brick on the street elevation above the ground floor and monolithic granite piers and spandrels forming the storefront framework on the ground-floor elevations. Throughout the years they have housed such uses as general store, bank, post office, hardware store, barber and restaurant. The upper stories were used for offices and for social and recreational purposes. Today, they still carry on a commercial function (see Existing Conditions Section). The photograph of the Commercial Buildings (Figure 2.3) shows the commercial buildings and was found in the files of the North Smithfield Heritage Society; its date and origin are not known.

\subsubsection{Stone Arch Bridge}

The Stone Arch Bridge is a state designated "historic bridge". It crosses the Branch River and is located just south of the entrance to the Mill Complex. This bridge consists of two similar semi-circular stone granite arches, each $40^{\prime}$ in span. The Stone Arch Bridge is significant as an excellent, wellpreserved example of 19th century stone-arch construction. Of the bridges inventoried by the Department of Transportation and 
FIGURE 2.3 COMMERCIAL BUILDINGS

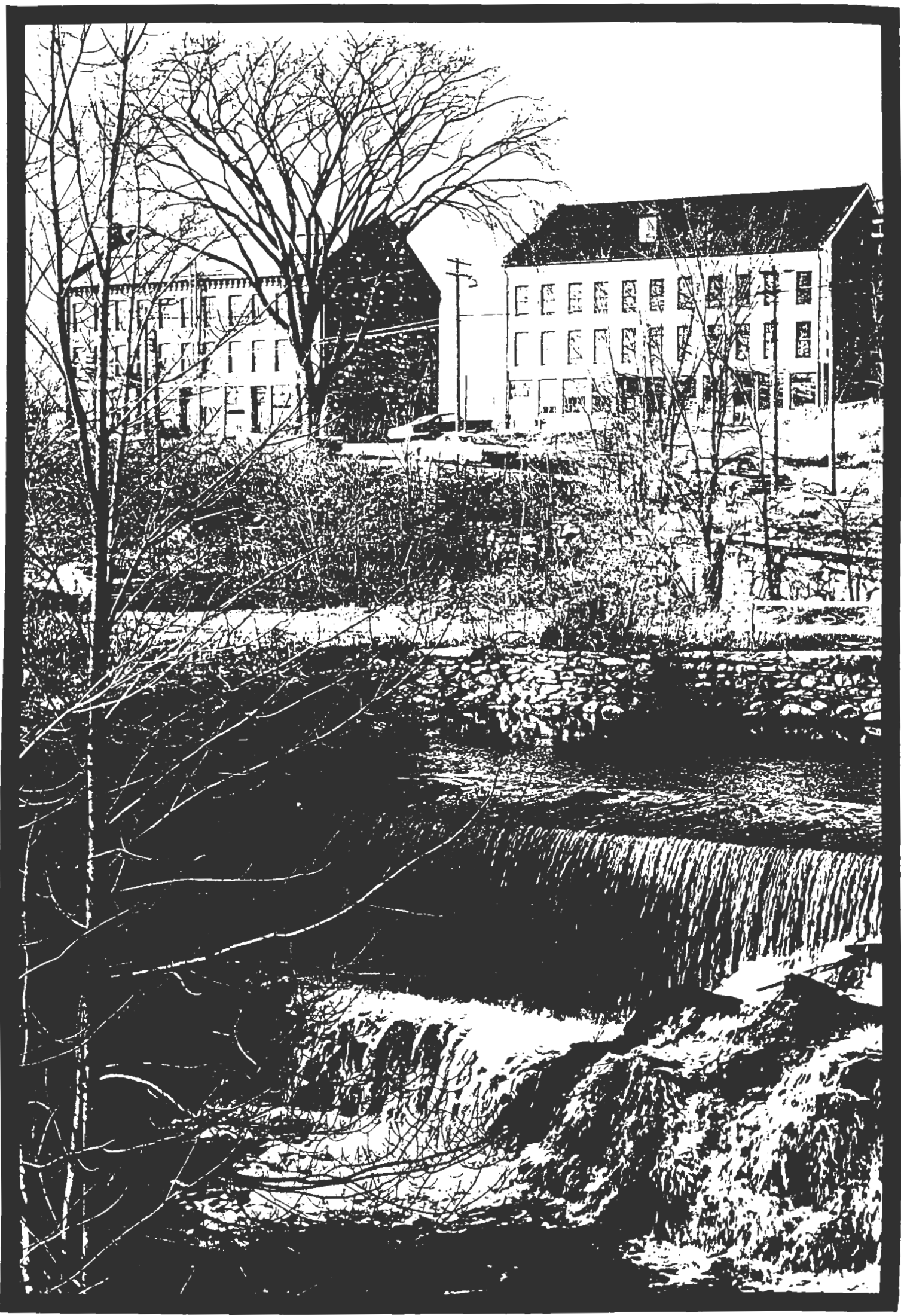

SOURCE: NORTH SMITHFIELD HERITAGE ASSOCIATION 
the RI Historic Preservation Commission, "it is one of the larger stone arches, one few with more than one span, and one of the least altered: the 1940 sidewalk (recently re-built) and the railing repairs are the only elements which are not part of the bridge's historic appearance". The bridge was built in 1855 by the Town of North Smithfield for $\$ 2,000$. Its granite construction reflects the need felt by many towns to provide better more permanent bridges than could be built in wood at the time. "Because textile mills needed substantial bridges in order to safely transport bulk materials, stone bridges are almost entirely found in mill villages." An old photograph of this bridge was located in the Heritage society is shown below. The age of the old photograph is not known.

Figure 2.4 Stone Arch Bridge

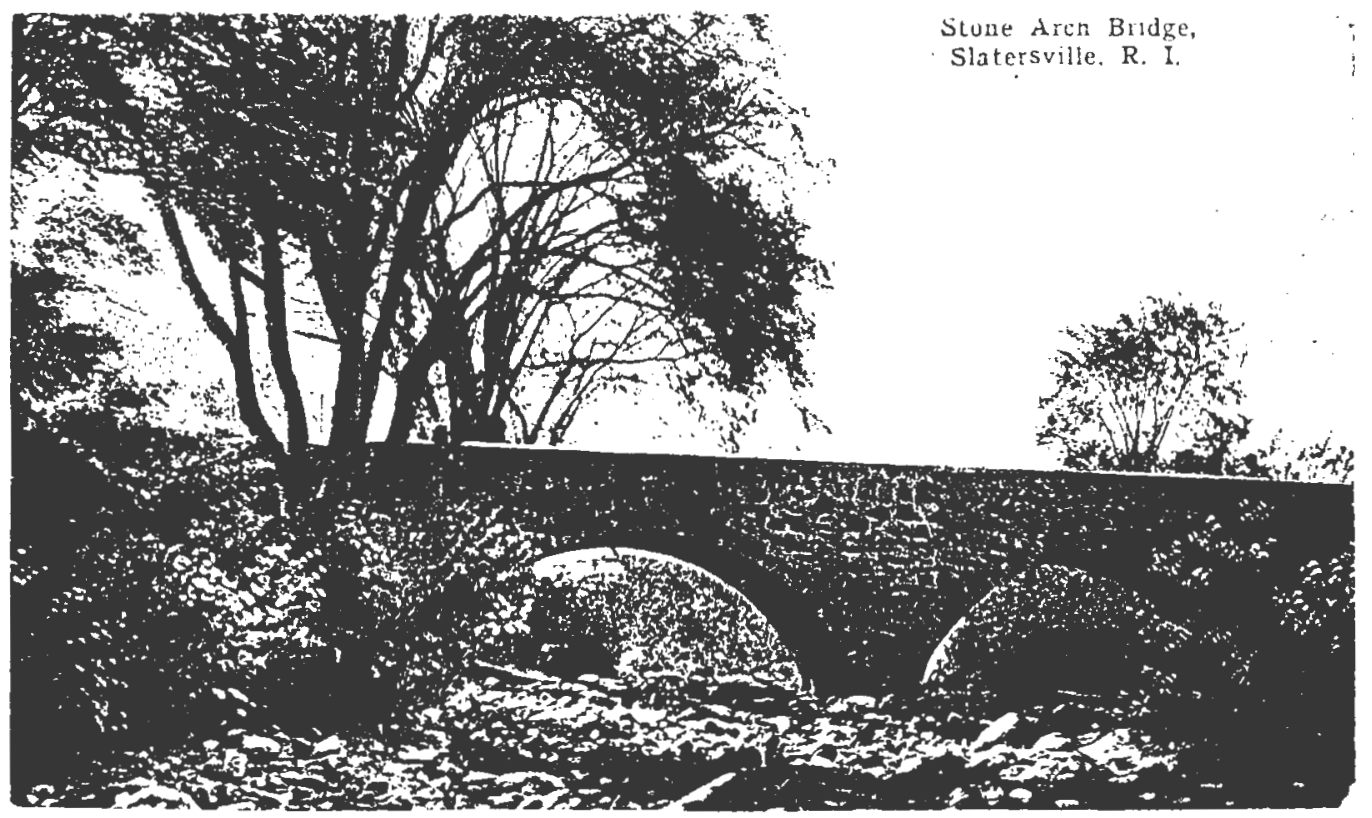

Source: North Smithfield Heritage Association 


\subsection{THE SIGNIFICANCE OF HISTORIC DISTRICT DESIGNATION TO THE}

\section{REDEVELOPMENT OF SLATERSVILLE}

Slatersville physical location, pattern and appearance is the result of its development as a mill village; dependant upon the Branch River for power to run the mill. Today, Slatersville is nationally significant as one of the first and most successful mill villages in the United States. This well-preserved historic district still reflects its early history as well as subsequent changes after the Civil war and in the early twentieth century. ${ }^{15}$ This unique history has been recognized on state and national levels through historic district designation and National Heritage Corridor designation by the U.S. Congress. slatersville's location within the National Heritage Corridor provides it with a regional identity as well as affording it regional planning efforts. This designation does not, however, provide the study area or Slatersville with mandates for preservation or protection of its historic or cultural resources. Slatersville is listed on the National Register of Historic Places and the State Register of Historic Places. The National and State Registers" are "the official federal and state lists of significant historic properties which are worthy of preservation". ${ }^{16}$ North Smithfield became a Certified Local

15 State of RI Historical Preservation Commission, Executive Director, Letter to President of N. Smithfield Town Council re: Slatersville Historic District. September 4, 1991.

16 The Rhode Island Historic Preservation Plan. The R.I. Historical Preservation Commission. June 1989. 
Government (CLG) in October, 1992. CLG's are municipalities which administer an historic zoning program which has been approved by the Rhode Island Historic Preservation Commission (RIHPC). Local historic zoning regulates rehabilitation in designated local historic districts. Currently, the Village of Union is the only "local" historic district in North Smithfield which falls under the purview of the Local Historic District Commission and therefore historic district regulations. slatersville has been considered for local historic district designation, but to date has not been selected for this status. Several methods could be used by North Smithfield to give local control over the historic features in slatersville; Historic District or Conservation District Designation.

Fears that local historic designation will inflate property values, and subsequently property tax is recognized. Many residents feel that designation will place excessive economic burdens on residents of fixed incomes or at worst, involuntarily displacement. The most recent research on this issue shows no conclusive evidence to prove that property values will increase after designation. ${ }^{17}$ The timing of the designation appears to be a minor determining factor in this issue. Specifically, how much restoration of the historic area has occured when designation occurs. The research concludes that "it is fair to state that most of the results to date do not support the view that

17 The Impacts of Historic District Designation, Planning and Policy Implications. Dennis E. Gale. APA Journal, 325. Summer, 1991. 
designation is associated with accelerated growth in property assessments or sales prices.

Conservation Districts are cited as the latest zoning tool to preserve neighborhood character. ${ }^{18}$ Conservation Districts are being used by local governments to protect neighborhoods with distinct cultural, historical, and architectural qualities.

In general terms, the Conservation District combines components of historic preservation and aesthetic zoning. Local governments target particular areas for neighborhood preservation much as they would designate historic preservation districts. Although the conservation district typically protects groups of buildings that have some historical significance, historic preservation is not the only goal. Conservation Districts also seek to preserve an area's cultural, architectural, and aesthetic ambience. New construction, alterations, and demolition are subject to review much as in historic districts, but changes are not regulated as stringently. Neighborhood character is maintained in spite of allowing some alterations that would not normally be allowed in traditional historic districts. ${ }^{19}$

Legally, Conservation Districts are considered valid exercise of the municipal police power if it is not unreasonable either in its scope or in the public purpose it seeks to further, similar to zoning.

Conservation Districts can be administered by a local historic agency or a local planning or zoning agency. The type of agency overseeing administration of the conservation district usually influences the selection criteria and goals. The districts generally adopt their own design standards. Preferably

18 Conservation Districts: Latest Zoning Tool to Preserve Neighborhood Character. Mark S. Dennison. Zoning News, American Planning Association. November, 1992.

19 Ibid 
they should contain standards that can be applied with as much precision as possible. Reference to specific types of building components, such as doors, windows, facades, chimneys, roofs, and other architectural design elements, will place objective criteria in the ordinance, thereby diminishing the potential for subjective decisions by the review board. ${ }^{20}$

$20 \quad$ Ibid 


\section{CHAPTER 3 \\ EXISTING CONDITIONS}

In order to determine the possibilities of what should be done with the study area, the current conditions need to be analyzed. For the purpose of this study, existing conditions which have been determined to be important in terms of redevelopment of the study area include previous plans which exist for the area, land use, zoning, circulation, infrastructure, and streetscape. This chapter will inventory the existing conditions and provide an analysis of these conditions, in the form of a summary of findings. The existing features which will be discussed appear on Map 3.1 .

\subsection{EXISTING PLANS RELATING TO SLATERSVILLE}

Because of the historic significance of slatersville and the entire Blackstone River Valley area, much recognition has been given to the area in the form of research and plans. These plans have been proposed by State Agencies because of the designation of the Blackstone River Valley as a National Heritage Corridor in 1986. It is important to recognize these plans within the confines of this study to ensure continuity and consistency among recommendations, as well as goals and policies. These plans consider elements such as recreation, economic development, and cultural resources. The Town of North Smithfield's most recent Comprehensive Plan has embraced all of these elements and 


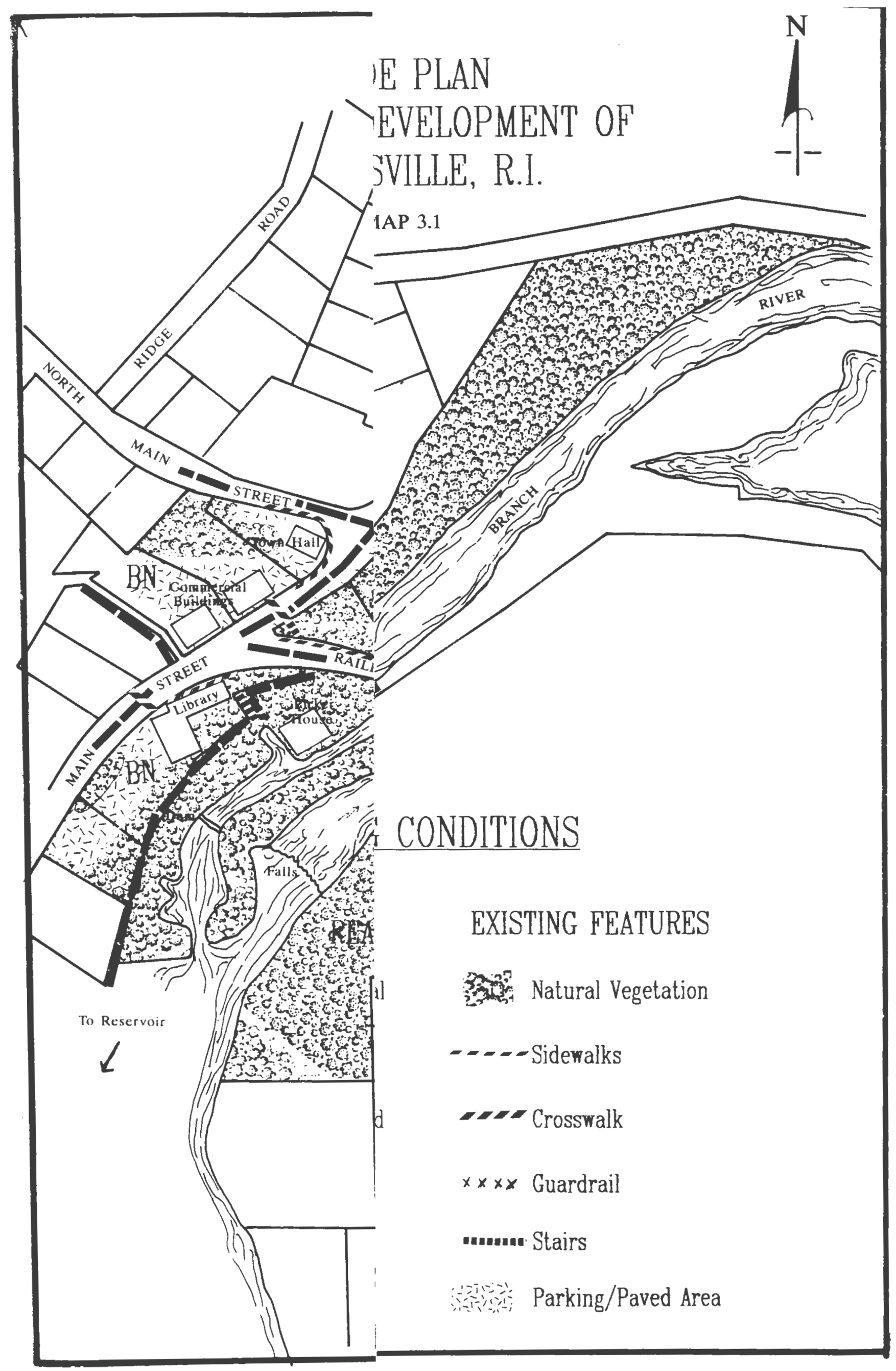


recognizes the impact of National Heritage Corridor designation. This Plan will be discussed first, followed by other pertinent plans. The Comprehensive Plan encourages such existing recreation plans as the Blackstone River Bikeway and Park and the redevelopment of the Library's Centennial Park.

The Town of North Smithfield Comprehensive Plan lists the mill as an ideal site for economic development. The Land Use Element of the Town's Comprehensive Plan supports adaptive re-use of the Mill site as a mixed use development including offices, research and development and housing to provide the area with additional land suitable for economic development. The economic benefits which will result from a successful re-use plan are outlined in the Economic Development Element of the Town's Comprehensive Plan and include: attracting new industry, generating work for local tradesmen participating in the rehabilitation programs and increased tourist interest which will generate revenue for local businesses.

The Comprehensive Plan also identifies a Cultural Resources Action Program which recommends several efforts within Slatersville: securing additional municipal office space near the Town Hall; upgrading and signing the N. Smithfield Library Association's Centennial Park; improving pedestrian accessibility; and encouraging mixed use for redevelopment at the mill complex.

The Economic Assessment for the Blackstone River Valley National Heritage Corridor lists the resources of the Mill site 
as an area of special interest for developing "visitor attraction materials". They highlight the entire Village of slatersville, including the mills, mill housing, dam, bridge, canal and mill pond as an exceptional, compact tourist stopping point, easily accessed from Route $146 .{ }^{20}$

The Blackstone Linear Park Guide Plan ${ }^{21}$ suggests Slatersville as a northern terminus of the Linear Park because of its' riverway, recreation, conservation and cultural features and that it be advertised through interpretive literature, distributed at the Library, discussing the areas resources. The Blackstone River Park Master $\mathrm{Plan}^{22}$ makes more specific recommendations regarding the above discussed linear park and gives examples of the style of the suggested interpretive literature.

These plans recommend planning strategies on a regional level for what currently exists within the Blackstone River Valley, which includes North Smithfield. For this reason, the existing physical conditions and uses within the study area must be analyzed.

20 Economic Assessment for the Blackstone River Valley National Heritage Corridor. Prepared by the office of Travel, Tourism and Recreation and the Department of Resource Economics, The University of Rhode Island. November, 1989.

21 The Blackstone Linear Park Guide Plan. Lee Pare \& Associates, Inc. and Everett Associates. January 1985.

22 The Blackstone River Park Master Plan. State of Rhode Island Department of Environmental Management. June 1986. 


\subsection{BUILDING INVENTORY}

\subsubsection{Town Hall}

The Town Hall building (Figure 3.1), or Memorial Town Building, is presently being used for just that purpose. It houses the majority of the municipal offices, such as Town clerk, Tax Assessor, and Town Administrator. The building has two floors with approximately 3,500 - 4,000 square feet of office space.

\section{Figure 3.1}

"Memorial Town Hall" with "Park" in forground

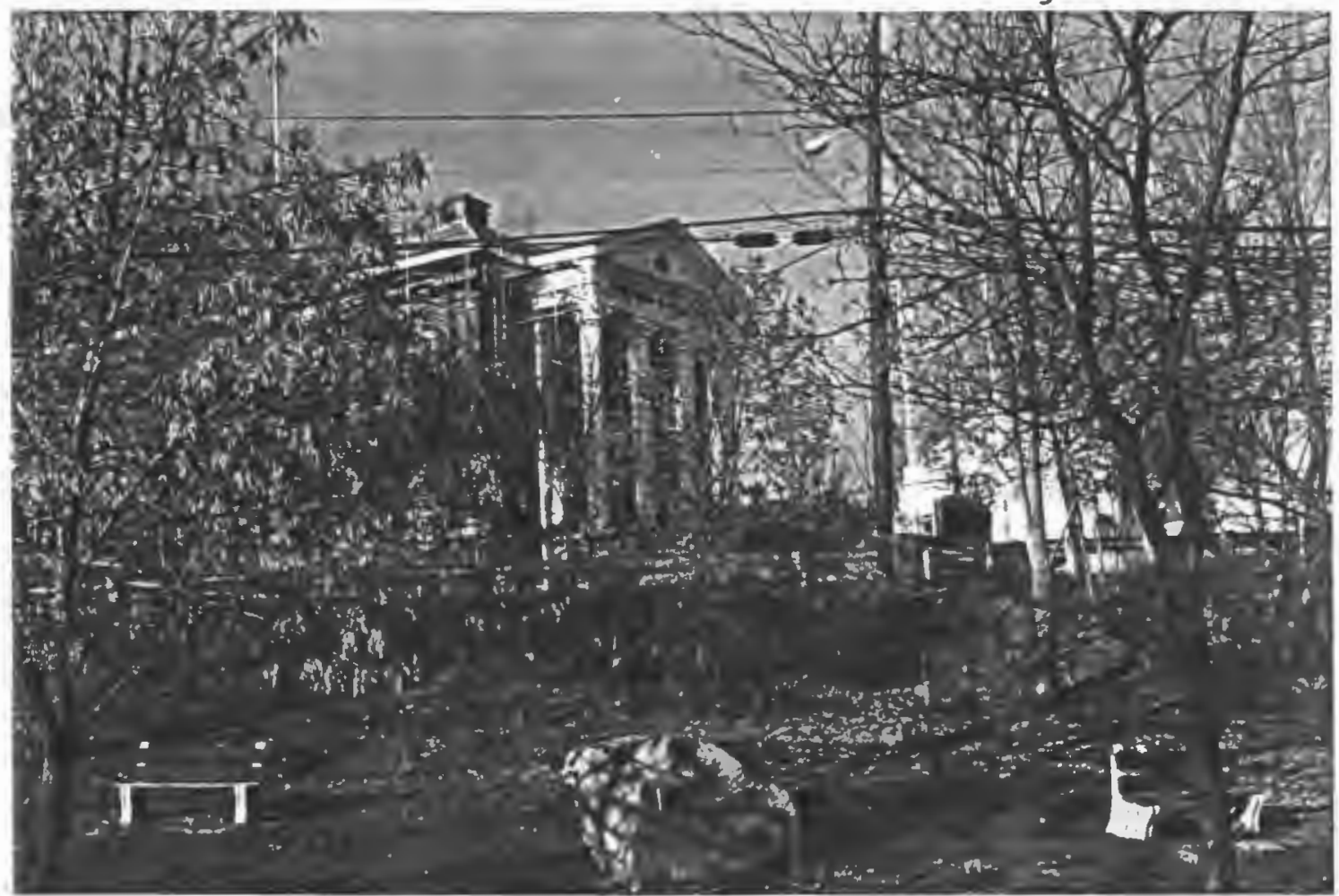

\subsubsection{Commercial Buildings}

The two commercial buildings (Figure 3.2) are currently in different stages of renovation and use. Both buildings have three floors and approximately 5,000 square feet of office space. 
Figure 3.2 - "Commercial Buildings"

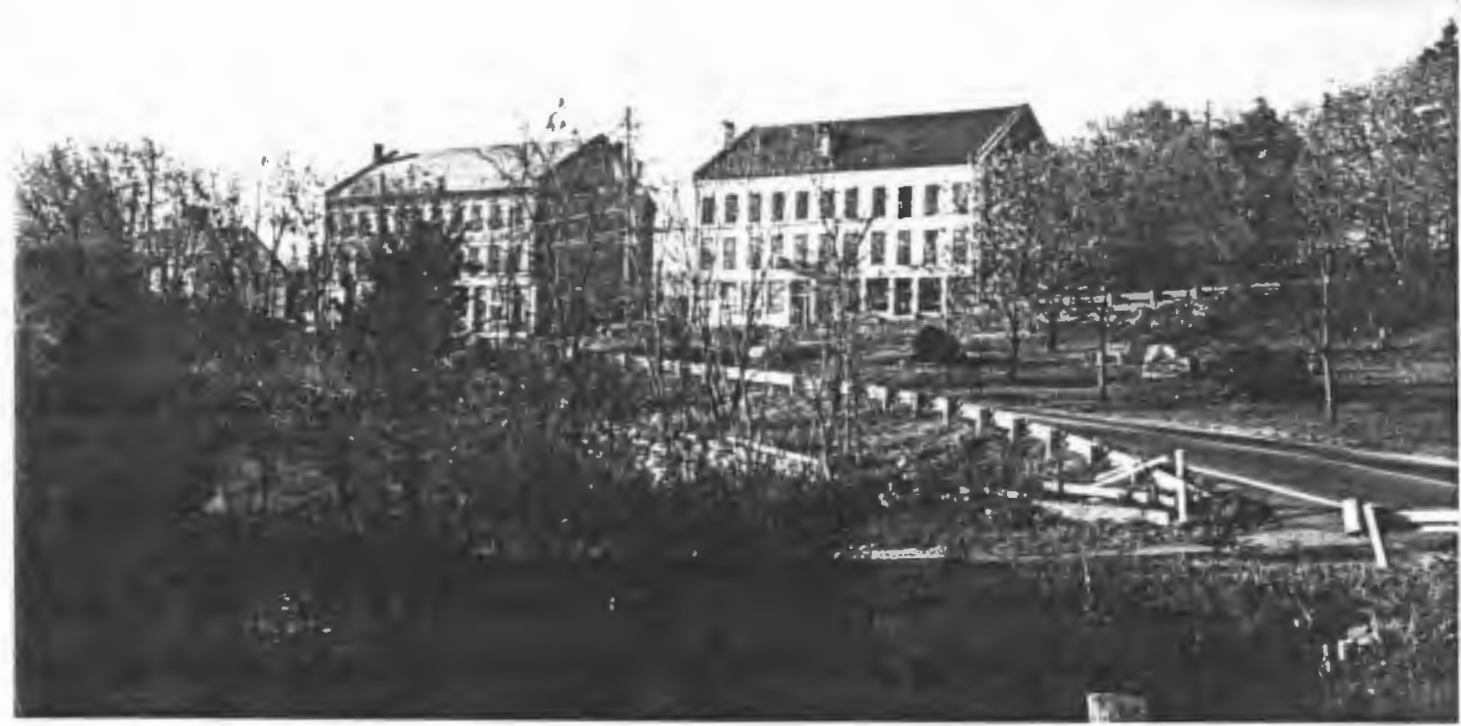

The first commercial building is owned by Fleet Bank, who is currently the only tenant. The windows on the third floor are boarded up. Parking for this building is minimal at present, but has the potential for expansion. The second commercial building has several small businesses and has three floors which are finished for business occupancy. There are four entrances on the front of the building so that separate entrances are possible for various businesses. This building utilizes (not marked) approximately four parking spaces in the front of the building and has a parking lot with 10 - 15 spaces in the rear of the building. Parking spaces are also designated between the two buildings, adjacent to the buildings providing approximately 4 additional spaces. 


\subsubsection{Library Association's Centennial Park}

This park is currently in a state of disrepair and therefore it is underutilized. The former park amenities, such as benches, (Figure 3.3) are old and the park has not had constant upkeep, nor does it have adequate signage. Although the trails have been cleared recently they are still fairly overgrown. Remnants of the Western Mill Complex are still evidenced by raceway bulkheading (Figure 3.4), the dam (Figure 3.5) and the Picker House (Figure 3.6). The park affords spectacular view of the Reservoir and it's falls (Figure 3.7). The park is still accessible from both the Library parking lot and Railroad street, just north of the Stone Arch Bridge.

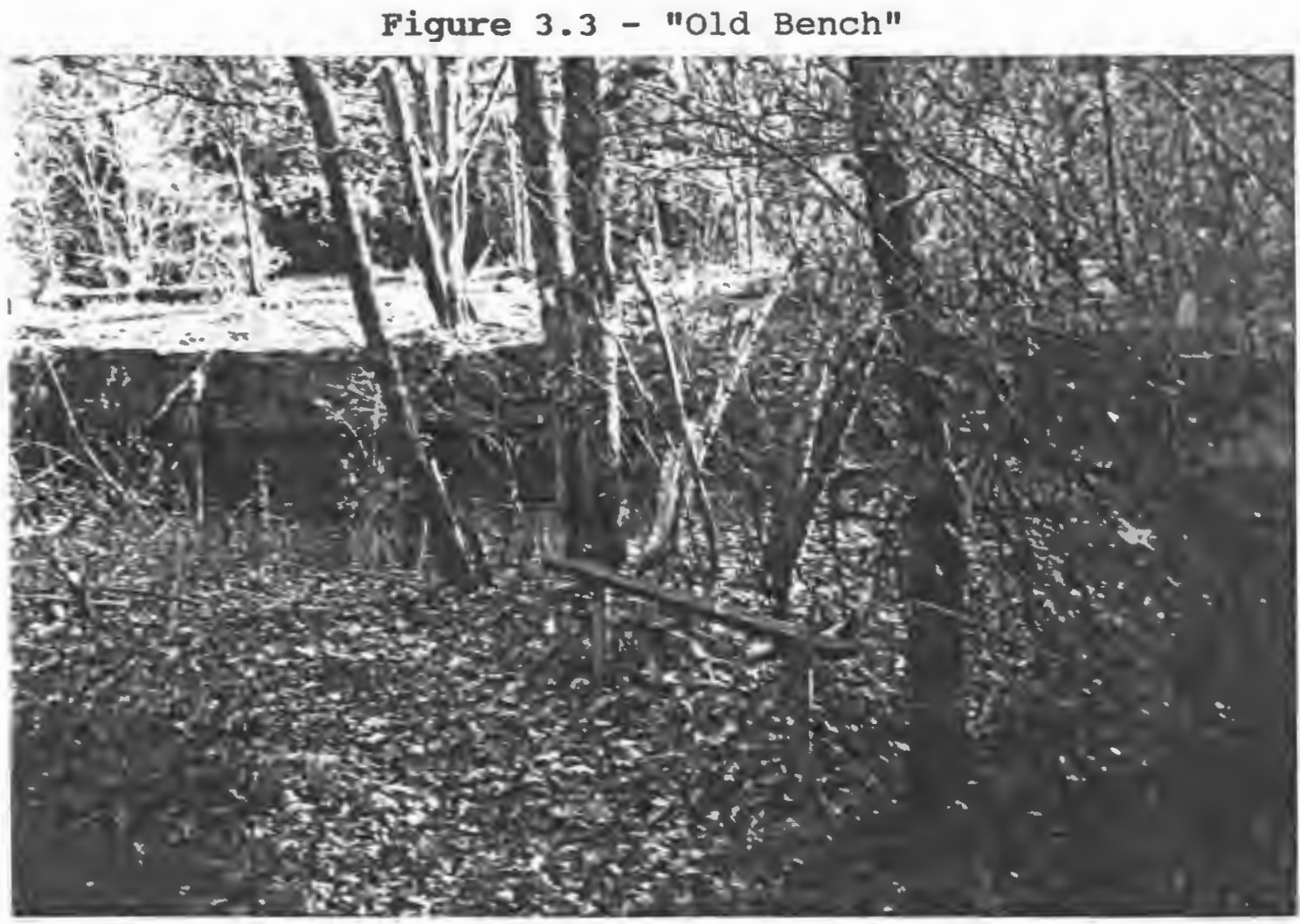


Figure 3.4 - "Raceway (notice bulkheading)

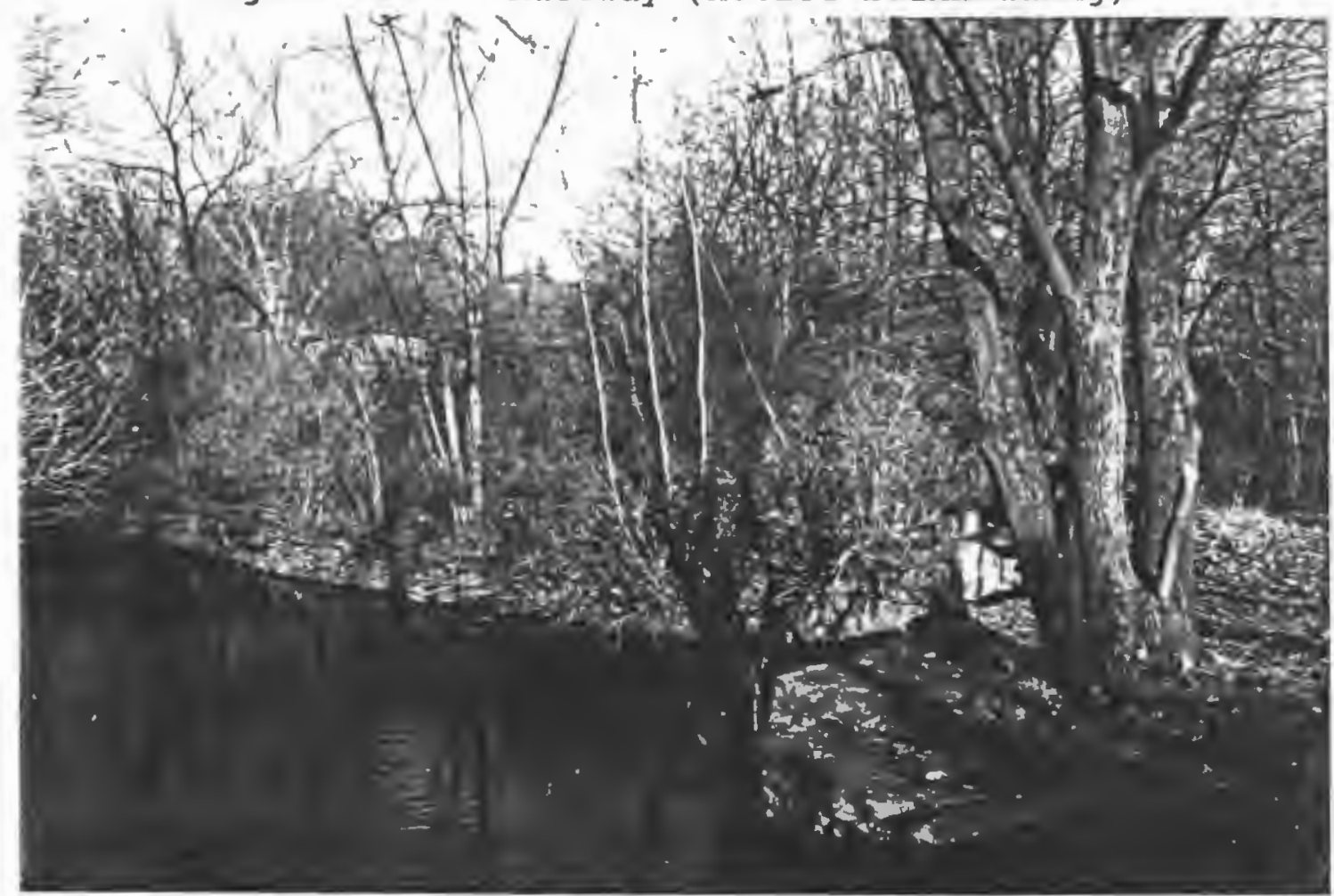

Figure 3.5 - "Dam"

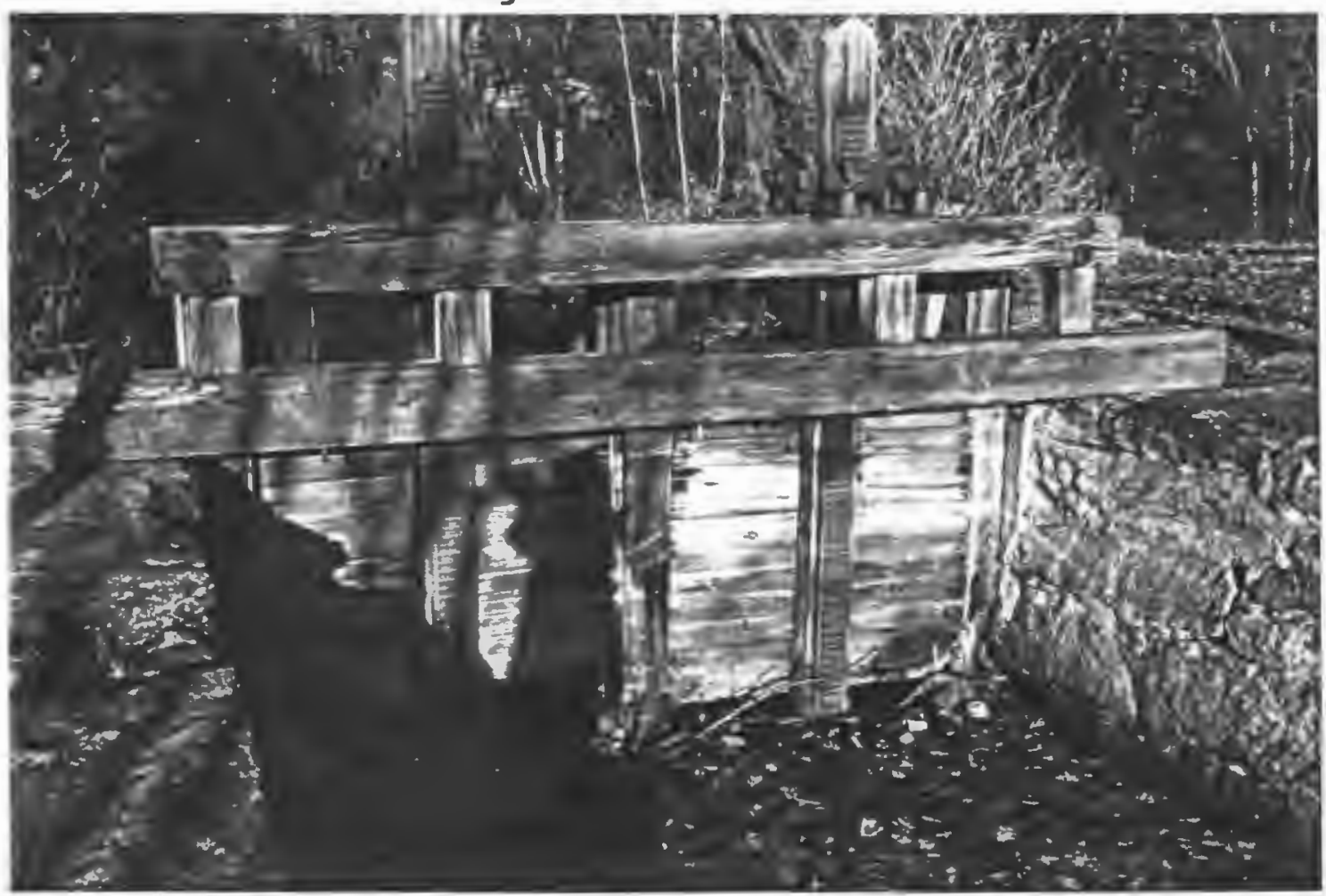


Figure 3.6 - "Picker House"

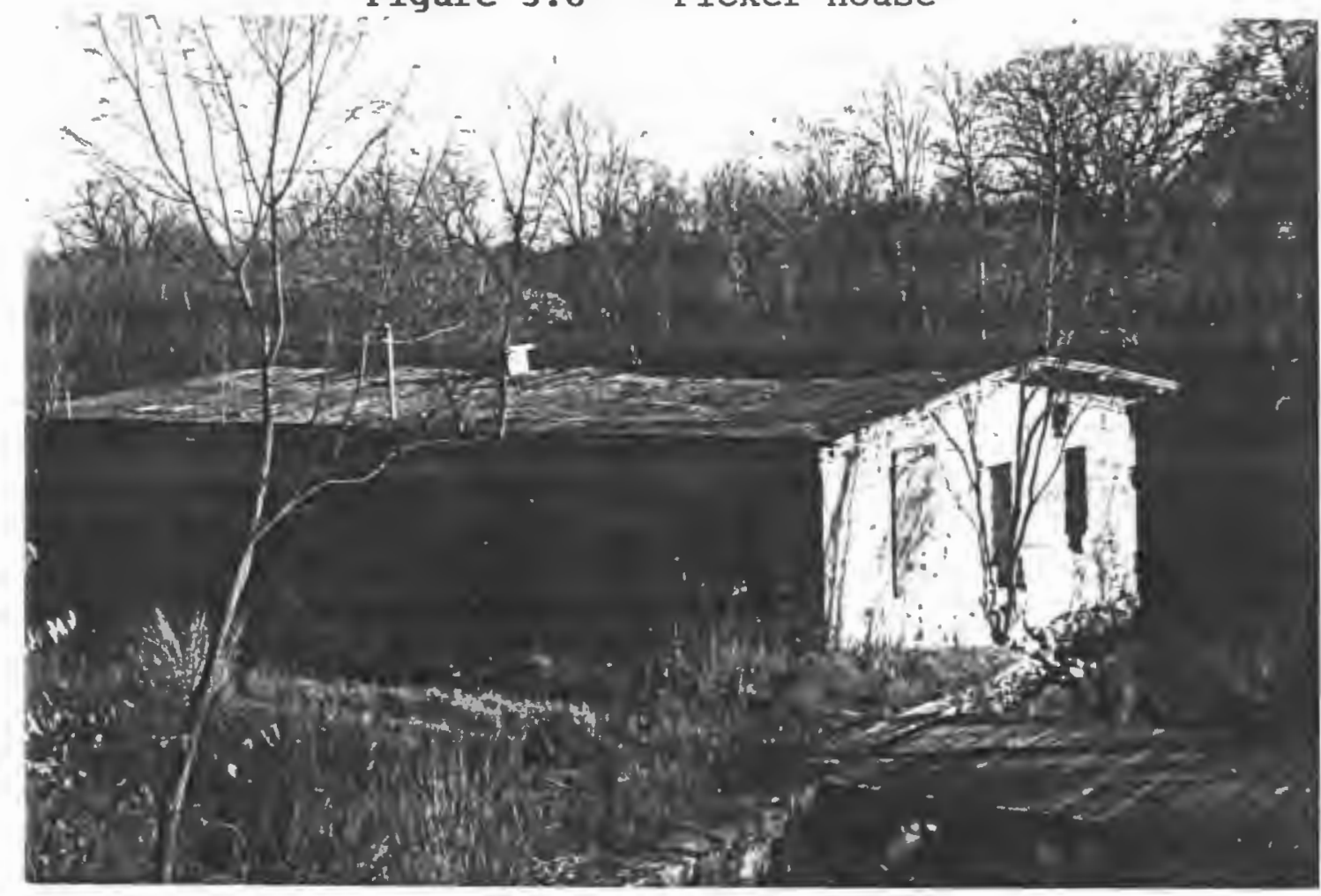

Figure 3.7 - "View of Reservoir"

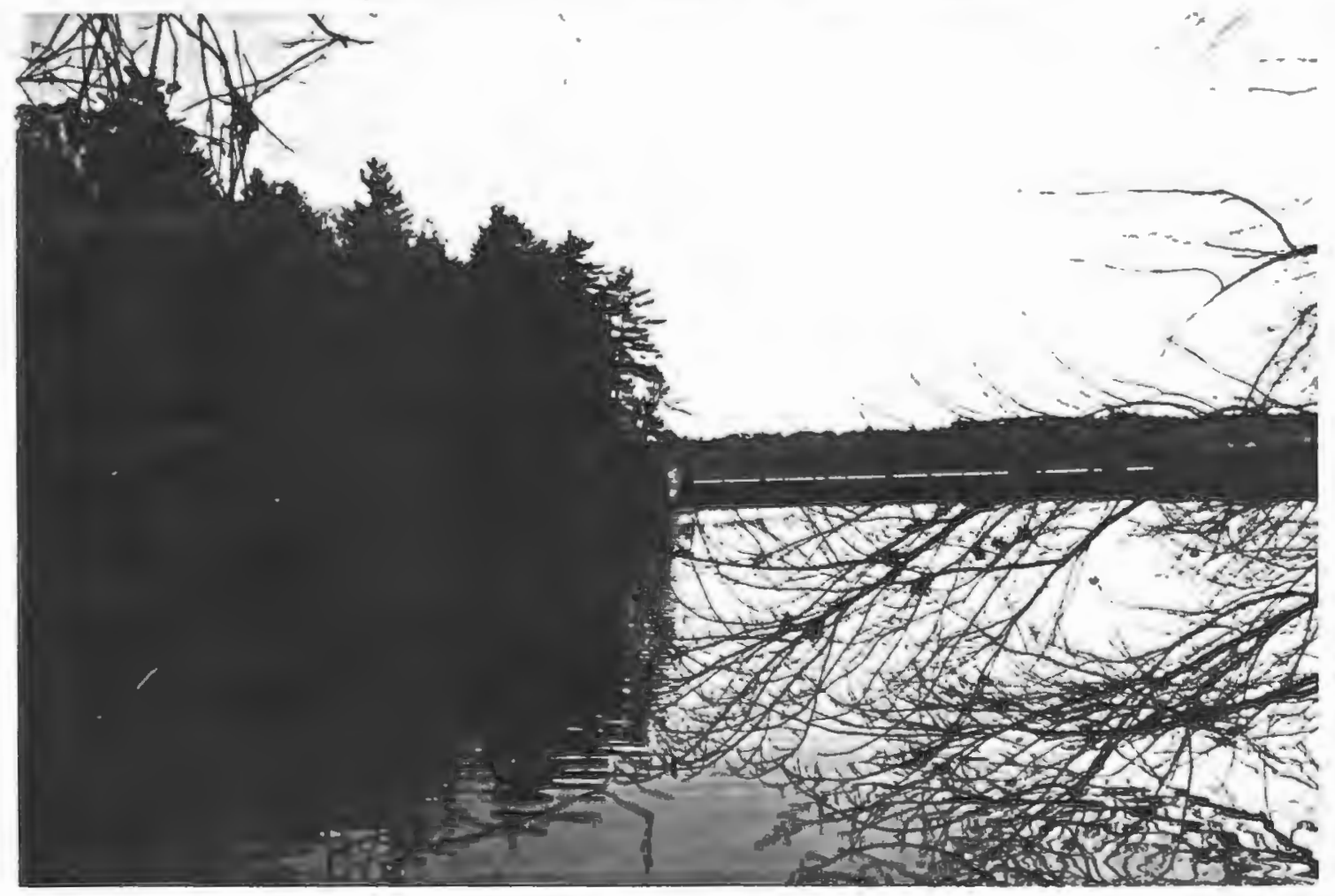




\subsubsection{Slatersville Mill Complex}

Following is a discussion of each building and the most upto-date information on its condition, space and contents. The site is improved with the following buildings and associated structures which were originally used for the slatersville Finishing Company and later the Kendall Company: an office building, two (2) mills; a "weaving building" which, until recently, housed the manufacturing activities of Glas-Kraft; a powerhouse with a smokestack; garage; reservoir building and a gatehouse. All of the buildings located within the slatersville Mill Complex are currently unoccupied.

The exterior of the site is improved with asphalt driveways and parking areas and most of the site is surrounded by chain link fencing along the property lines. Outside lighting is located in the parking area with overhead lights mounted on poles. Three (3) above-ground storage tanks for the storage of asphalt and one (1) for the storage of gasoline are located to the south of the boiler room in the Glas-Kraft building. Two (2) above-ground storage tanks for wax are located outside on the south side of the building as well.

The office building - A one and a half story, wood-frame building which is believed to be the oldest mill-related building in slatersville and probably was built in 1806 or 1807 . It served as an office building since at least 1894. Until recently it housed the offices for Glas-Kraft. (forefront, right, Figure 3.8) 
The Slater No. 1 Mill building (Figure 3.8 , center) - A five-story stone structure which is located approximately 200 feet west of the office building. It was constructed in 1826 on or near the site of the original slater Mill which had burned earlier that year. This building is currently vacant and in need of both interior and exterior repair. The interior of the building is typical for mill buildings and has structural columns throughout its length. The exterior of the building needs minor masonry work and major replacement work (such as windows and roof) and the old metal loading dock located along the front of the building is deteriorated to the point of partial collapse. The large bell housed within the belfry, is still in working condition.

Figure 3.8 - "Mill Complex" from Route 5

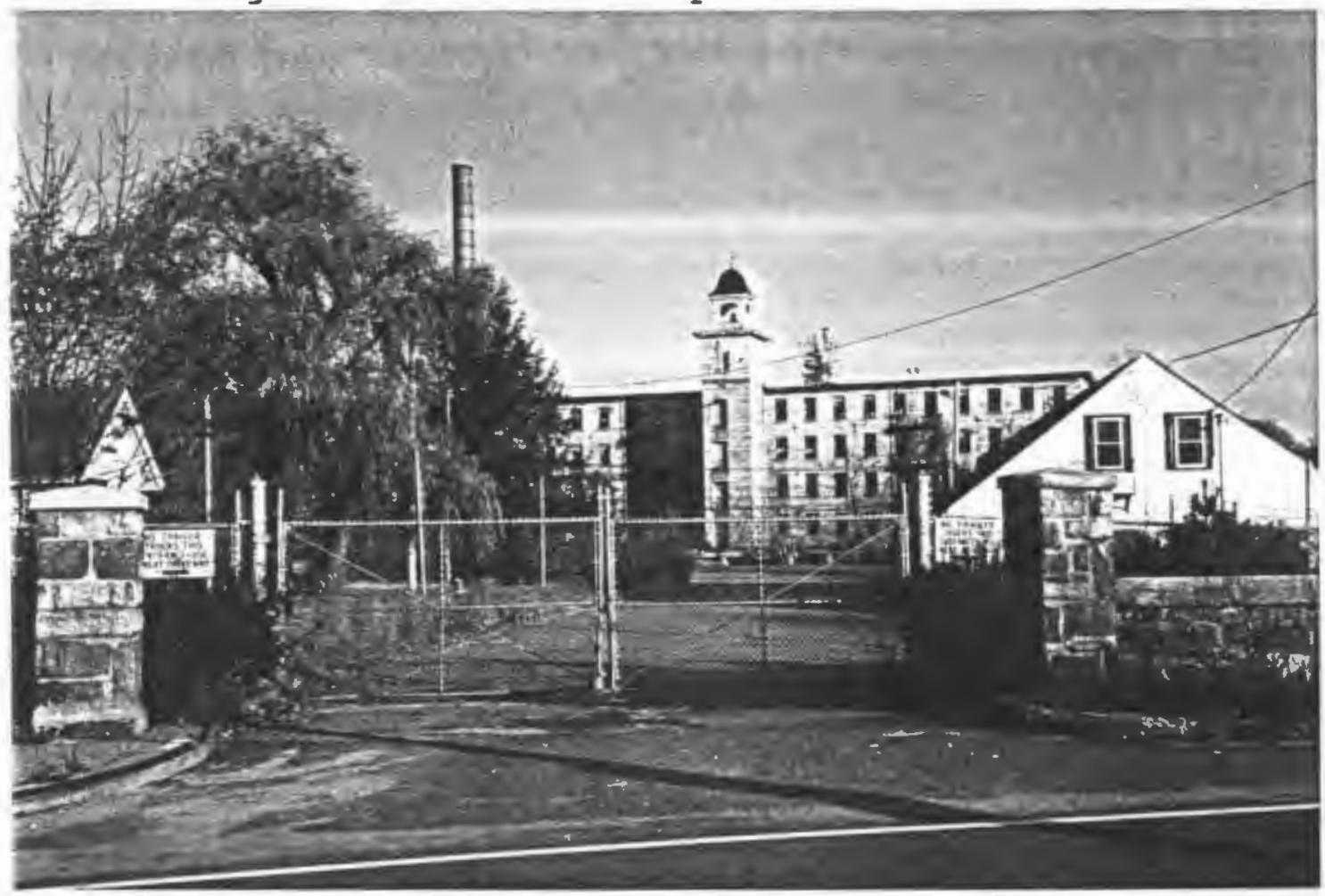


The Slater No. 3 Mill building - is located approximately 200 feet east of the No. $1 \mathrm{mill}$. This is a four-story stone building constructed in 1843. A portion of the wheel house and water power equipment, situated at the southwest corner, is still intact; water from the raceway flows freely through the system. The building also has a double row of structural columns throughout its length. This building had been used most recently for storage space, however, it is currently vacant and in need of extensive interior and exterior repair.

The Weaving Building - A two-story brick building located approximately 100 feet north of the mill buildings and separated from them by the slatersville canal. It was constructed in 1894 along the mill trench and was used as the bleachery building for the Kendall Company which ran a finishing mill. Early surveys of the site from the 1930's indicate that the following operations were conducted in this building when it was utilized as a textile operation: bleach house, for starching, drying and bleaching; dye house, for dyeing and mercerizing; caustic room; drug room; mixing room; office; dye house laboratory; general laboratory; and "kier" house. Until recently, this building housed the manufacturing activities of Glas-Kraft, Inc. which owned the site from 1959 until 1992. Glas-Kraft used the former weaving building most recently as follows: first floor - stock room, electrical room, fire pump room, boiler room, machine shop, repair shop, paper storage area, finished good storage area, shipping office, and loading room; second floor - spun glass 
room, three (3) offices, print shop, locker room, cafeteria, and laboratory. There is also a partial basement under this building which is utilized for tanks which store No. 5 fuel oil and heat transfer oil as well as a water expansion tank. The building currently contains the machinery of the former Glas-Kraft, Inc. company as well as unfinished and finished goods.

The Garage - Located approximately 30 feet east of the No. 1 Mill building, this building was a 19th century gas house which had been converted and used for storage.

The Power House - located to the rear of the complex is an open building with extremely high ceilings (approximately 30 feet) with doors on each side. With the exception of pigeons living in the building and the associated waste, the building appears to be in good condition. To the north of the power house is the 225 foot high smoke stack which is accessible through a small opening at ground level.

Reservoir Building - Next to the power house is a building which houses a reservoir for the mill operation's processed water. A portion of the building, facing the power house, is vacant. This building appears to be in excellent condition and has a concrete ramp and a loading dock on the front of the building. 


\subsection{ZONING}

The study area has within its boundaries four different zoning districts (Map 3.1). These districts include REA-120 Rural Estate-Agricultural, RS - Suburban Residential, BN Neighborhood Business, and M - Manufacturing. The Town Hall, the two commercial blocks and the Library are located within the Neighborhood Business, the Library's centennial Park is within the Rural Estate Agricultural-120 district and the Slatersville Mill Complex is within the Manufacturing District. The property behind (east of) the Mill Complex is zoned Suburban Residential. The intent of each district as stated in the Zoning ordinance ${ }^{23}$ is as follows:

REA-120 - Rural Estate-Agriculture. This district is established to provide protection to areas where the conservation of water bodies and streams are of significant importance; where development may be threatened by flood, or would increase the danger of flood elsewhere and where limited agricultural pursuits and low density residential uses are compatible with open-space objectives.

RS - Suburban Residential. This district is established to provide areas where medium-low density residential uses now appear feasible because community facilities such as public water or sewers are likely in the foreseeable future.

BN - Neighborhood Business. This district is established to provide areas for the retailing of convenience goods and furnishing of some personal services. It is primarily intended to serve the day-to-day needs of persons living nearby, although the secondary function of serving community-wide needs is permitted also.

M - Manufacturing. This district is established to provide areas suitable for industrial development, research and certain transportation, storage and utility uses. In addition, certain commercial services catering primarily to the needs of industry and its employees are permitted within the provisions of this

23 Zoning. Town of North Smithfield, Rhode Island. 1991. 
ordinance. In order to maximize the potential of this district, it is the intent of this ordinance not to permit incompatible uses which require extensive improvements and thus hinder industrial development.

Each district has different permitted uses and lot area requirements. The permitted uses, broken down by zoning district, are presented in Table 1 ( $X=$ permitted use, $N=$ not permitted and $\mathrm{S}$ = permitted by special exception) and the lot area requirements, also broken down by zoning district, are presented in Table 2 . 


\section{TAEIE $3-1$ \\ Permitted uses by zoning District 24}

\subsubsection{Agricultural uses}

(1) Raising of animals within a dwelling

(2) Non-commercial raising of animals outdoors . (excluding pets, watchdogs and apiary)

(3) Pets, watchdogs

(4) Apiary

(5) Commercial raising of animals and animal byproducts (excluding piggeries and mink farming)

(6) Non-commercial raising of crops

(7) Commercial raising of crops (excluding greenhouses and nursery)

(8) Commercial greenhouse, nursery

(9) Unique agricultural pursuits (breeding station, experimental farm)

(10) Roadside stand for the sale of produce raised on the site (excluding Christmas trees)

(11) Sale of produce raised on the site (excluding Christmas trees)

(12) Natural Christmas tree sales

\subsubsection{Residential uses}

(1) Single family detached dwelling (without professional office space)

(2) Single family detached dwelling with professional $\quad \mathrm{X} \quad \mathrm{X} \quad \mathrm{N} \quad \mathrm{N}$ office space (see office uses)

(3) Two family dwelling

(4) Multi-family dwellings, apartments; maximum of
REA RS BN M

$\mathrm{X} \quad \mathrm{X} \quad \mathrm{X}$

$X \quad \mathrm{X} \quad \mathrm{X}$

$X \quad X \quad X$

$X \quad X \quad N$

$S \quad S \quad N \quad X$

$X \quad \mathrm{~N} X$

$S \quad S \quad N \quad X$

$S \quad X \quad N \quad S$

$\mathrm{S} \quad \mathrm{N} \quad \mathrm{N} \quad \mathrm{S}$

$\mathrm{S} \quad \mathrm{N} \quad \mathrm{N} \quad \mathrm{S}$

$X \quad X \quad X$

$\mathrm{X} \quad \mathrm{T} \quad \mathrm{X} \quad \mathrm{X}$

$\begin{array}{llll}\mathrm{N} & \mathrm{X} & \mathrm{X} & \mathrm{X}\end{array}$

$N \quad S \quad N \quad N$

21 Copied from Town of North Smithfield Zoning ordinance, section 5.4, District Use Regulations. pp. 1136.1 - 1144.1 


\section{TABIE $3-1$ \\ Permitted Uses by zoning District (con't)}

100 bedrooms. (only in areas served by public water)

(5) Attached dwelling for operator or owner of a principal use

(6) Customary home occupation (non-professional acREA RS BN M tivity) performed by the occupant and using no more than $150 \mathrm{sq}$. ft. of the area of one floor. (see definition)

(7) Lodging, rooming, tourist or guest house

(8) Dormitory for a permitted use

(9) Hotel

(10) Motel

(11) Rest home, convalescent home, nursing home

(12) Public housing for the elderly

(13) Mobile home park

5.4.3. Office uses

$\begin{array}{llll}\mathrm{N} & \mathrm{S} & \mathrm{N} & \mathrm{N}\end{array}$

(1) Professional office in the home (professional activity by a resident of the premises utilizing no more than 300 sq. $\mathrm{ft}$. of floor space and not employing more than two persons full or part-time)

(2) Non-professional office in the home (real estate, insurance agent, etc.)

(3) Temporary real estate office (one year only)

(4) Bank, financial institution

$\begin{array}{llll}S & S & S & S\end{array}$

(5) Office building

(6) Office as an accessory to a wholesale or manufacturing use

(7) Office trailer (construction)

5.4.4. Public and semi-public uses

(1) Public schools or college

$\begin{array}{cccc} & & & \\ X & X & X & X \\ N & S & N & N \\ N & S & N & N \\ N & N & S & N \\ N & N & N & N \\ N & S & N & N \\ N & S & N & N \\ N & N & N & N\end{array}$

$\begin{array}{llll}N & X & S & N\end{array}$ 


\begin{tabular}{|c|c|c|c|c|c|}
\hline & $\begin{array}{c}\text { TABI.E } 3-1 \\
\text { Permitted Uses by zoning District }\end{array}$ & $(\operatorname{con}$ & & & \\
\hline & & REA & $\mathrm{RS}$ & $\mathrm{BN}$ & $M$ \\
\hline (2) & $\begin{array}{l}\text { Private schools, nursery, professional, and private } \\
\text { trade schools (excludes trade schools utilizing } \\
\text { heavy machinery for instructional purposes and } \\
\text { individual tutoring) }\end{array}$ & $N$ & S & S & $\mathrm{S}$ \\
\hline$(3) \cdot$ & Trade schools utilizing heavy machinery for in- & 17 & 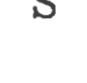 & & \\
\hline & structional purposes & $\mathrm{N}$ & $\mathrm{N}$ & $\mathrm{N}$ & $\mathrm{X}$ \\
\hline (4) & $\begin{array}{l}\text { Individual tutoring utilizing less than } 200 \mathrm{sq} . \mathrm{ft} \text {. } \\
\text { of floor space }\end{array}$ & $\mathrm{X}$ & $\mathrm{X}$ & $\mathrm{X}$ & $\mathrm{X}$ \\
\hline$(5)$ & Religious institution & $\mathrm{X}$ & $\mathrm{X}$ & $N$ & $\mathrm{~N}$ \\
\hline (6) & $\begin{array}{l}\text { Charitable institution (excluding sales or indus- } \\
\text { trial activity) }\end{array}$ & $\mathrm{N}$ & $\mathrm{X}$ & $N$ & $\mathrm{~N}$ \\
\hline (7) & Charitable institution (sales or industrial activity) & $\mathrm{N}$. & $N$ & S & $\mathrm{X}$ \\
\hline (8) & $\begin{array}{l}\text { Cultural activities including library, museums, ac- } \\
\text { quariums }\end{array}$ & $N$ & $\mathrm{X}$ & $\mathbf{S}$ & $N$ \\
\hline (9) & $\begin{array}{l}\text { Hospital or clinic (excluding mental or alcoholic } \\
\text { treatment, drug addiction or communicable di- } \\
\text { sease.) }\end{array}$ & $\mathrm{N}$ & $\mathbf{S}$ & $N$ & $\mathrm{~N}$ \\
\hline$(10)$ & $\begin{array}{l}\text { Hospital or clinic for mental or alcoholic treat- } \\
\text { ment, or drug addiction }\end{array}$ & $N$ & $N$ & $\mathrm{~N}$ & $\mathrm{~N}$ \\
\hline$(11)$ & for communicable disease & $N$ & $N$ & $\mathrm{~N}$ & $\mathrm{~N}$ \\
\hline$(12)$ & Fire or police & $X$ : & $\mathrm{X}$ & $\mathrm{X}$ & $\mathbf{S}$ \\
\hline$(13)$ & Sewa & S & $\mathrm{N}$ & $\mathrm{N}$ & S \\
\hline$(13 \mathrm{~A})$ & Incinerator & $\mathrm{N}$ & $\mathrm{N}$ & $\mathrm{N}$ & $\mathrm{N}$ \\
\hline & $\begin{array}{l}\text { Other government structures (excluding penal, } \\
\text { garage or utility) }\end{array}$ & $N$ & $\mathrm{X}$ & $\mathrm{X}$ & $\mathrm{S}$ \\
\hline (15) & $\begin{array}{l}\text { Other government structures (penal, garage, } \\
\text { utility) }\end{array}$ & $N$ & S & $\mathbf{S}$ & $\mathrm{S}$ \\
\hline$(16)$ & Semi-public utility structures & $S$ & $\mathrm{~S}$ & S & S \\
\hline$(17)$ & Fraternal and other non-commercial clubs & $\mathrm{N}$ & $\mathrm{X}$ & S & $\mathrm{N}$ \\
\hline$(18)$ & d for recreation social & & & & \\
\hline$(19)$ & $\begin{array}{l}\text { or other it } \\
\text { Cemetery }\end{array}$ & $\begin{array}{l}N \\
S\end{array}$ & $\begin{array}{l}S \\
S\end{array}$ & $\begin{array}{l}\mathrm{X} \\
\mathrm{N}\end{array}$ & $\begin{array}{l}N \\
N\end{array}$ \\
\hline
\end{tabular}




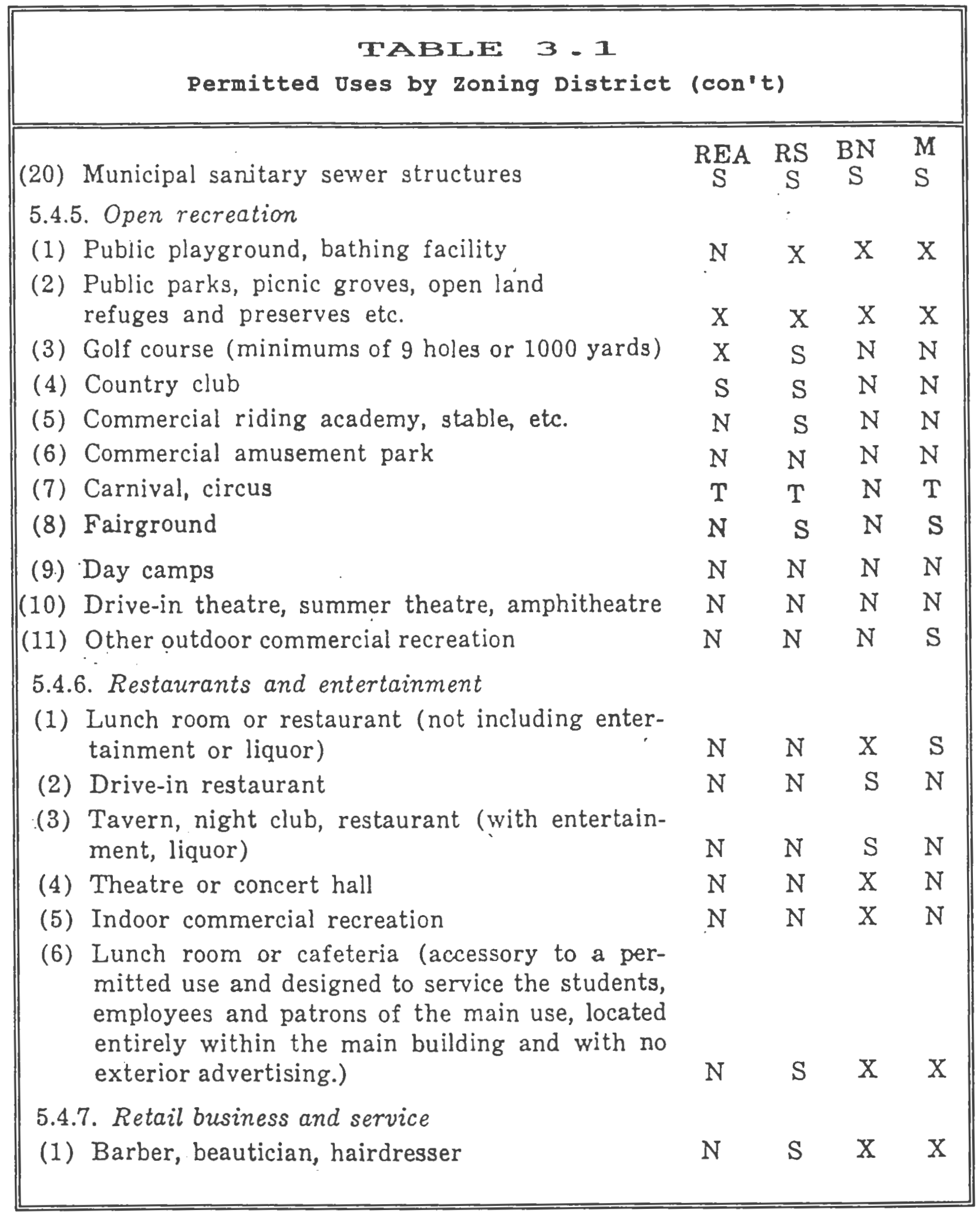




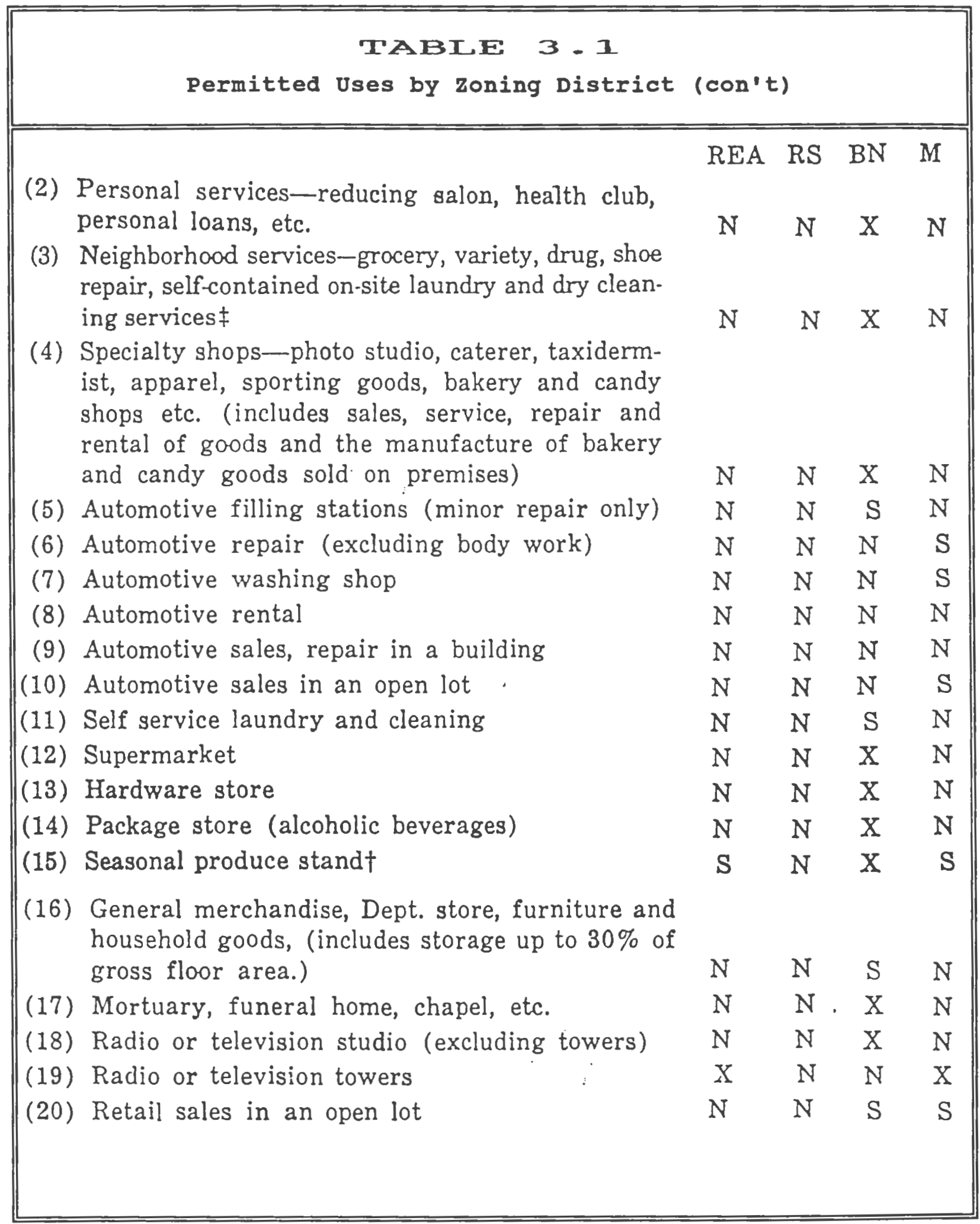




\section{TABIE: 3.1 \\ Permitted Uses by zoning District (con't)}

(21) Shopping center (in the $\mathrm{BH}$ and $\mathrm{BN}$ districts, restrictions on site. area, buffer requirements, and stage construction may be modified for shopping complexes of less than five (5) retail stores totalling less than 3,000 sq. ft. of floor area)

REA RS BN M

5.4.8. Wholesale business and storage

(1) Wholesale business and storage of nonflammable and nonexplosive material in a building.

(2) Open lot storage of building materials and machinery, etc.

(3) Open lot storage of serviceable automotive and boat equipment

(4) Open lot storage of solid fuel, sand and gravel

$\begin{array}{llll}\mathrm{N} & \mathrm{S} & \mathrm{S} & \mathrm{N}\end{array}$

(5) Open lot storage and wrecking of junk and salvage material

(6) Storage of flammable or explosive materials above ground

(7) Storage of flammable or explosive materials underground

$\mathrm{N} \quad \mathrm{N} \quad \mathrm{N} \quad \mathrm{X}$

$\mathrm{N} \quad \mathrm{N} \quad \mathrm{N} \quad \mathrm{S}$

$S^{*} \quad \mathrm{~N} \quad \mathrm{~N} \cdot \mathrm{S}$

$S^{*} \quad \mathrm{~N} \quad \mathrm{~N} \quad \mathrm{~S}$

(8) Retail outlet for a wholesale or storage use including the sale of ice, fuel oil, coal, wood

5.4.9. Service industries

(1) Laundry or dry cleaning plant

(2) Furniture, carpet, and rug cleannig plant

(3) Auto body or paint shop

(4) Blacksmith or welding shop

(5) Power-generating station or substation (excluding waste-to-energy power generation)

(6) Waste-to-energy power generation station or substation

$N \quad N \quad N \quad S^{*}$

S $\quad N \quad N \quad S$

S $\quad \mathrm{N} \quad \mathrm{S} \quad \mathrm{S}$

N $\quad N \quad S \quad X$

$\begin{array}{llll}\mathrm{N} & \mathrm{N} & \mathrm{N} & \mathrm{X}\end{array}$

$N \quad N \quad N \quad X$

$N \quad \mathrm{~N} \quad \mathrm{~N} \quad \mathrm{X}$

$N \quad N \quad N \quad X$

S S N X

$\mathrm{N} \quad \mathrm{N} \quad \mathrm{N} \quad \mathrm{N}$ 


\section{TABIE $3-1$ \\ Permitted Uses by zoning District (con't)}

5.4.10. Industrial uses

(1) Retail outlet for industrial operation

(2) The manufacture, compounding, processing or packaging of bakery goods, candy, cosmetics, drugs, food products (excluding meat, fish, yeast, vinegar and the rendering of fats and oils) and other similar operations

REA RS BN M

(3) The manufacture, compounding or assembly of articles using bone, shell, cellophane, plastics, fur, feathers, glass, leather, precious metals or stones, wood, textiles or tobacco and other previously prepared products.

$\mathrm{N} \quad \mathrm{N} \quad \mathrm{S} \quad \mathrm{X}$

(4) The manufacture and assembly from prepared materials of: musical instruments, clocks, toys, novelties, appliances, electronic devices, metal. products, machine tools, and machinery (not requiring the use of drop hammers and punch presses of over 100 tons) and other similar products.

(5) Automotive manufacture or assembly

(6) Boiler, lacomotive or railcar manufacture

(7) Iron or steel foundry

(8) Machinery or machine tool manufacture (requiring drop hammers or punch presses of over 100 tons)

(9) Smelter, blast furnace or blooming mill

(10) Carbon black manufacture

(11) Explosives manufacture

(12) Fertilizer manufacture

(13) Ice manufacture plant

$\mathrm{N} \quad \mathrm{N} \quad \mathrm{N} \quad \mathrm{X}$

(14) Chemical manufacture

(15) Plastic and pyroxlin manufacture

$\begin{array}{llll}N & N & N & X \\ N & N & N & S \\ N & N & N & S \\ N & N & N & S\end{array}$

$\begin{array}{llll}N & N & N & S\end{array}$

$\begin{array}{llll}N & N & N & S\end{array}$

$\begin{array}{llll}N & N & N & S\end{array}$

$\begin{array}{llll}N & N & N & S\end{array}$

$\begin{array}{llll}N & N & N & S\end{array}$

$\begin{array}{llll}\mathrm{N} & \mathrm{N} & \mathrm{N} & \mathrm{S}\end{array}$

N $\quad \mathrm{N} \quad \mathrm{N}$ S

$\mathrm{N} \quad \mathrm{N} \quad \mathrm{N} \quad \mathrm{S}$ 


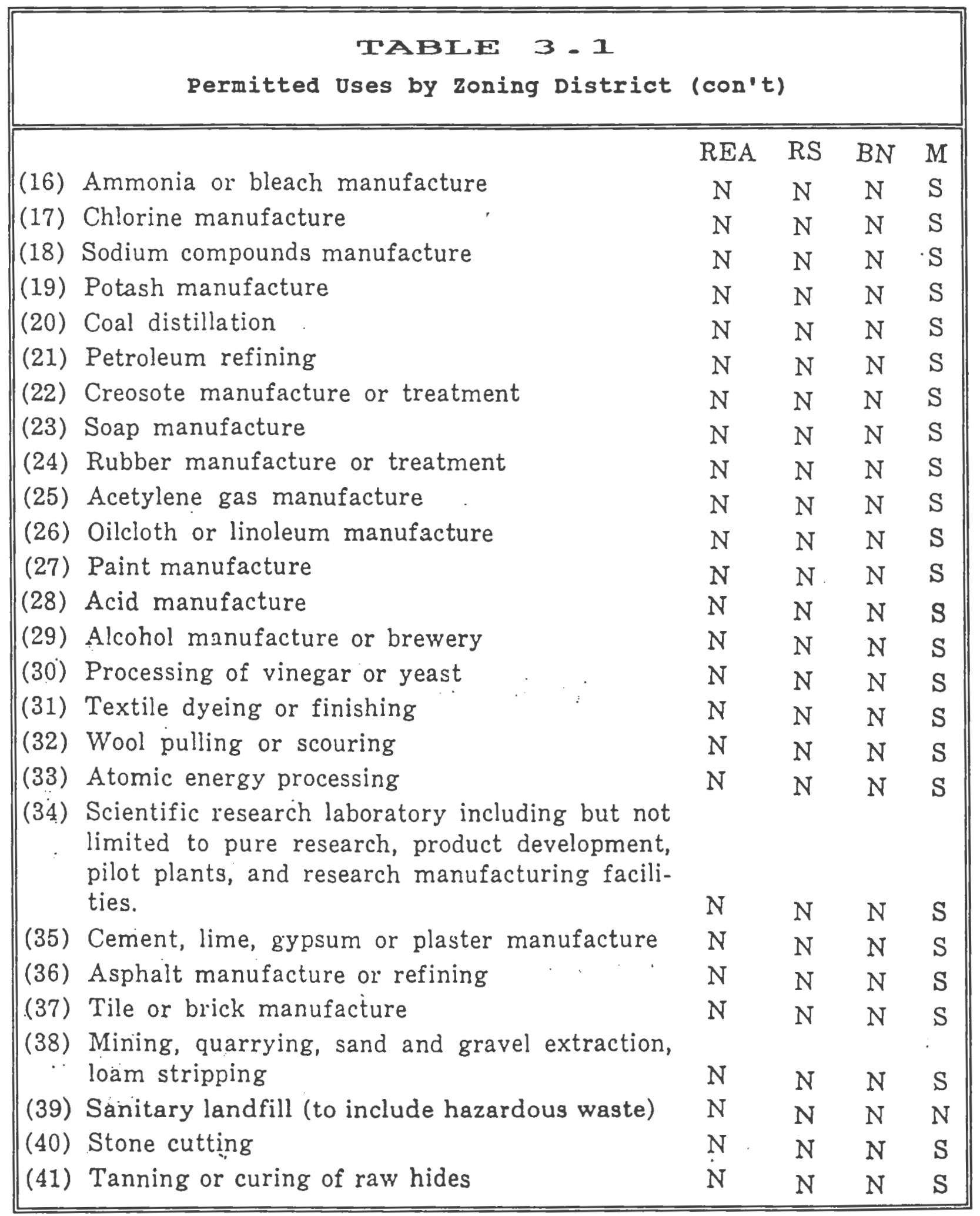




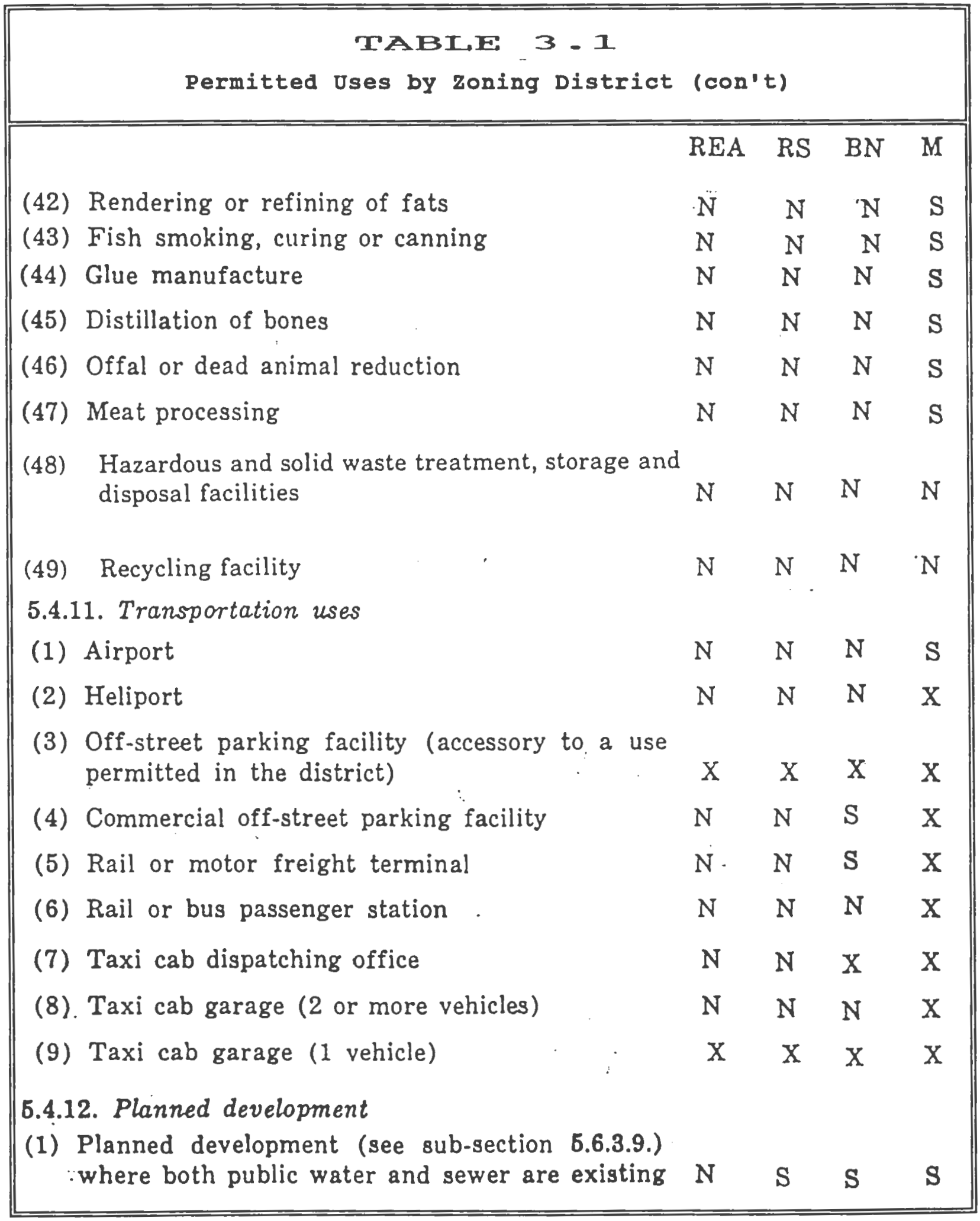




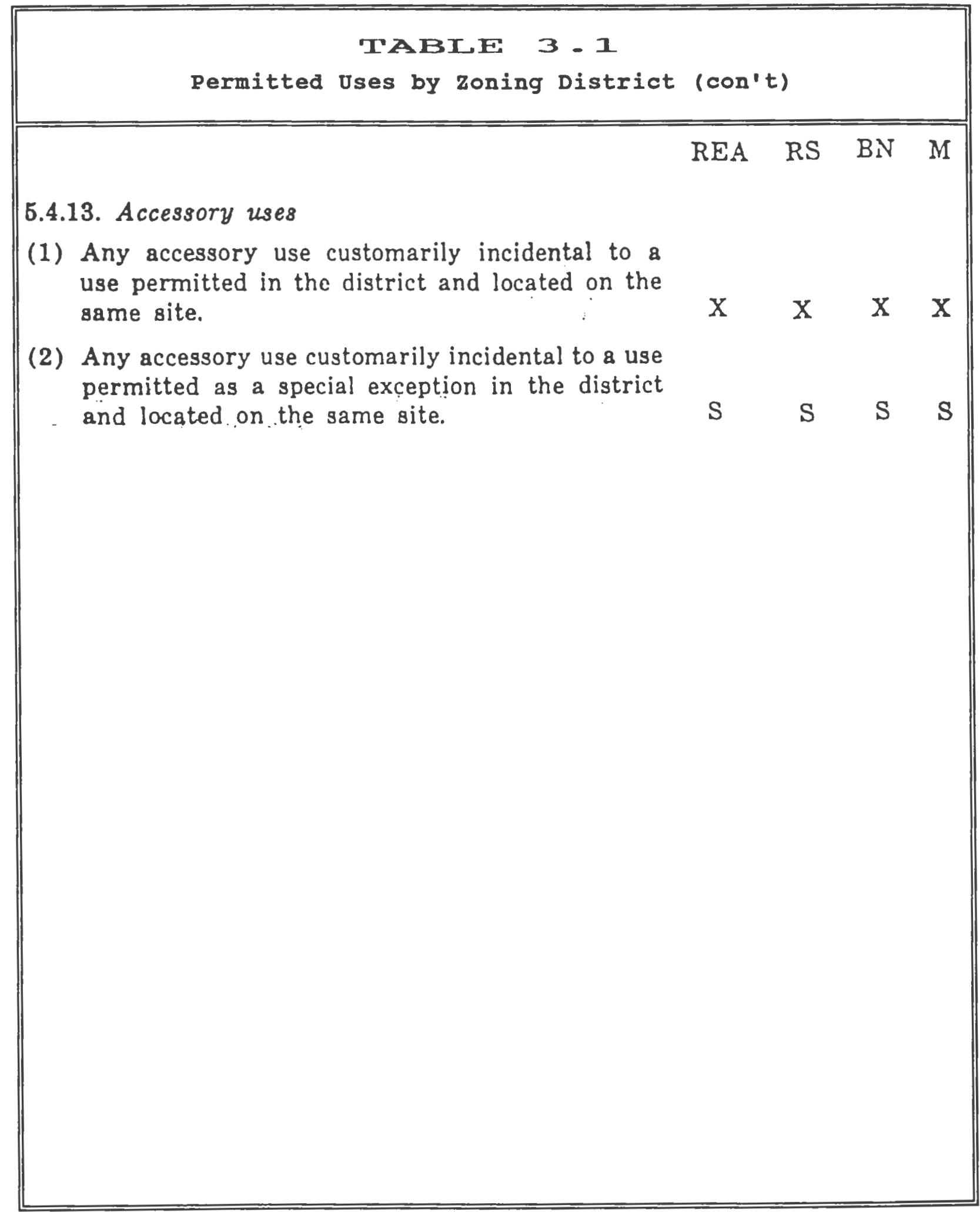




\begin{tabular}{|c|c|c|c|c|c|}
\hline \multicolumn{6}{|c|}{$\begin{array}{c}\text { TABI,E } 3-{ }^{2} \\
\text { Dimensional Regulations by Zoning District }\end{array}$} \\
\hline Requirement & $\begin{array}{l}\text { REA- } \\
120\end{array}$ & $\begin{array}{l}\text { RS- } \\
40\end{array}$ & Requi rement & BN & $\mathbf{M}$ \\
\hline $\begin{array}{l}\text { Lot Area } \\
\text { in sq. feet }\end{array}$ & 120000 & 40000 & $\begin{array}{l}\text { Distance } \\
\text { from Resid. } \\
\text { Zone Boundry }\end{array}$ & $\begin{array}{l}25 \\
\text { feet }\end{array}$ & $\begin{array}{l}100 \\
\text { ft. }\end{array}$ \\
\hline $\begin{array}{l}\text { Minimum Lot } \\
\text { width }\end{array}$ & $\begin{array}{l}300 \\
\text { feet }\end{array}$ & $\begin{array}{l}150 \\
\text { feet }\end{array}$ & $\begin{array}{l}\text { Minimum Yard } \\
\text { Depth }\end{array}$ & & \\
\hline $\begin{array}{c}\text { Min. Front } \\
\text { Yard }\end{array}$ & $\begin{array}{l}40 \\
\text { feet }\end{array}$ & $\begin{array}{l}30 \\
\text { feet }\end{array}$ & Rear: & $\begin{array}{l}30 \\
\text { feet }\end{array}$ & $\begin{array}{l}40 \\
\text { feet }\end{array}$ \\
\hline $\begin{array}{l}\text { Min. Rear } \\
\text { Yard }\end{array}$ & $\begin{array}{l}40 \\
\text { feet }\end{array}$ & $\begin{array}{l}40 \\
\text { feet }\end{array}$ & Side: & - & $\begin{array}{c}40 \\
\text { feet }\end{array}$ \\
\hline $\begin{array}{l}\text { Min. Side } \\
\text { Yard }\end{array}$ & $\begin{array}{l}25 \\
\text { feet }\end{array}$ & $\begin{array}{l}25 \\
\text { feet }\end{array}$ & Front: & $\begin{array}{l}25 \\
\text { feet }\end{array}$ & $\begin{array}{c}40 \\
\text { feet }\end{array}$ \\
\hline $\begin{array}{l}\text { Building } \\
\text { Coverage }\end{array}$ & $20 \%$ & $20 \%$ & $\begin{array}{c}\text { Floor Area } \\
\text { Ratio }\end{array}$ & .25 & 1.0 \\
\hline $\begin{array}{l}\text { Max. Height } \\
\text { Main } \\
\text { Building: } \\
\text { Accessory } \\
\text { Building: }\end{array}$ & $\begin{array}{l}35 \\
\text { feet } \\
20 \\
\text { feet }\end{array}$ & $\begin{array}{l}30 \\
\text { feet } \\
20 \\
\text { feet }\end{array}$ & $\begin{array}{l}\text { Max. Height } \\
\text { Main } \\
\text { Building: } \\
\text { Accessory } \\
\text { Building: }\end{array}$ & $\begin{array}{l}35 \\
\text { feet } \\
20 \\
\text { feet }\end{array}$ & $\begin{array}{l}35 \\
\text { feet } \\
20 \\
\text { feet }\end{array}$ \\
\hline
\end{tabular}

25 Information obtained from the Town of North Smithfield Zoning ordinance, Section 5.5, District Dimensional Regulations. pp. $1150.1-1152$. 


\subsection{CIRCULATION}

The study area is at the convergence of three roads, as shown on Map 3.1. The road network takes the shape of a " $\mathrm{Z}$ " where the points and the ends of the " $\mathrm{Z}$ " continue up, down and outward (side to side) respectively. Vehicular circulation to, from, and throughout the study area is achieved by these three roads: Main Street/School Street, North Main Street, and Route 5 (also known as Providence Pike and Railroad street).

Route 5 (Providence Pike and Railroad street) is owned and maintained by the state of Road Island. It is a one lane road in fairly good condition. It ends in slatersville at Main street, with the two commercial buildings directly ahead. To the south, Route 5 (Providence Pike and Railroad Street) eventually leads to Route 7, also a state road.

Main street runs from Route 102 west to the intersection of North Main Street, where it turns into School street which runs east to Victory Highway. Main street and School street are also owned and maintained by the state of R.I..

The closest major highway to the study area is Route 146 , which is approximately $1 / 4 \mathrm{mile}$ and accessed by School street, $\mathrm{N}$. Smithfield Industrial Highway, Pond Hill Road or Victory Highway (146A). Route 295 can be accessed off Route 146 or Route 5 to Route 7. It should be noted that School street has only an off ramp from Route 146 north bound.

A major circulation component of the study area which should be pointed out is the Stone Arch Bridge (Figures 3.9, 3.10), 
Figure 3.9 - "Stone Arch Bridge" (in foreground)

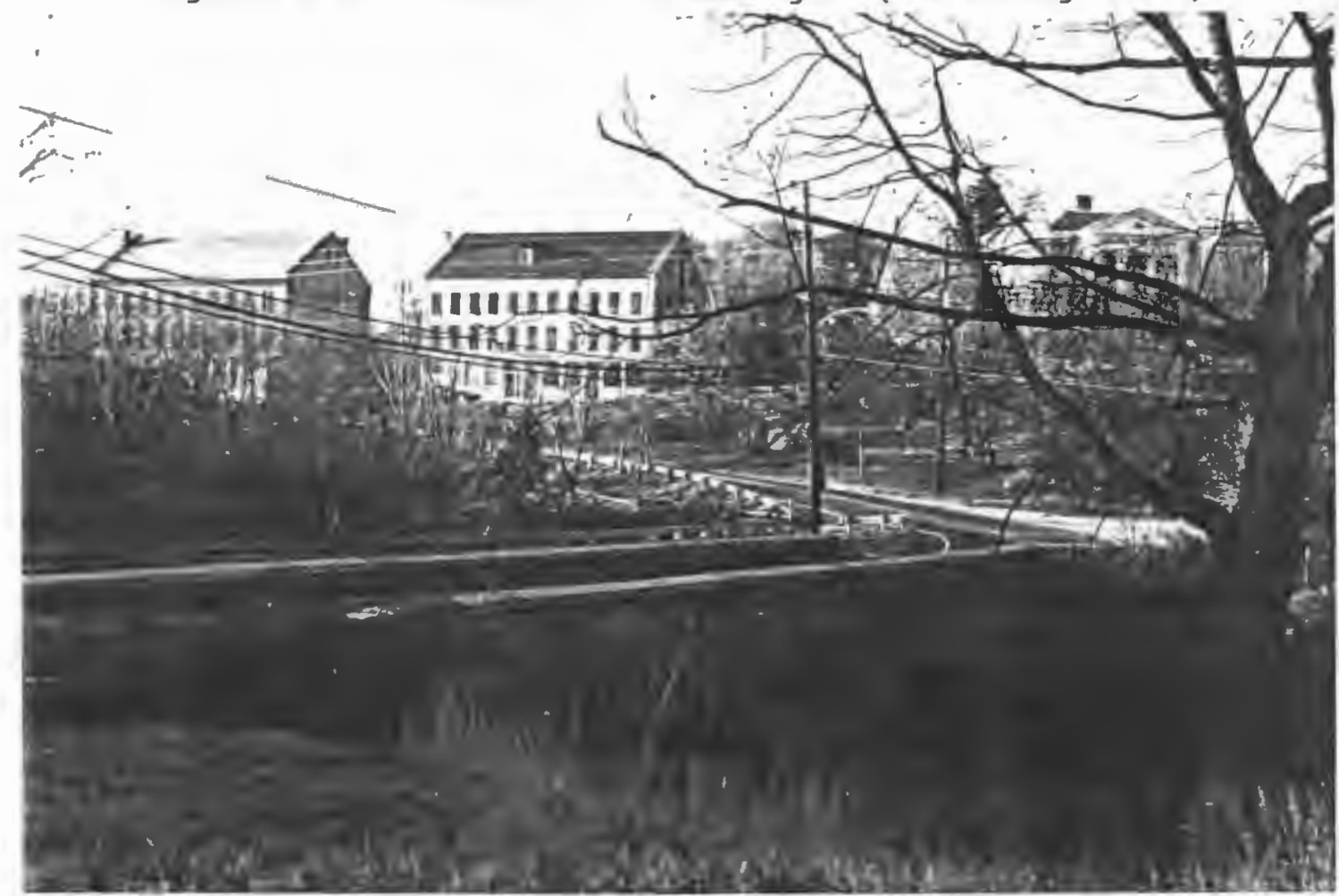

Figure 3.10 - Looking South Across the "Stone Arch Bridge"

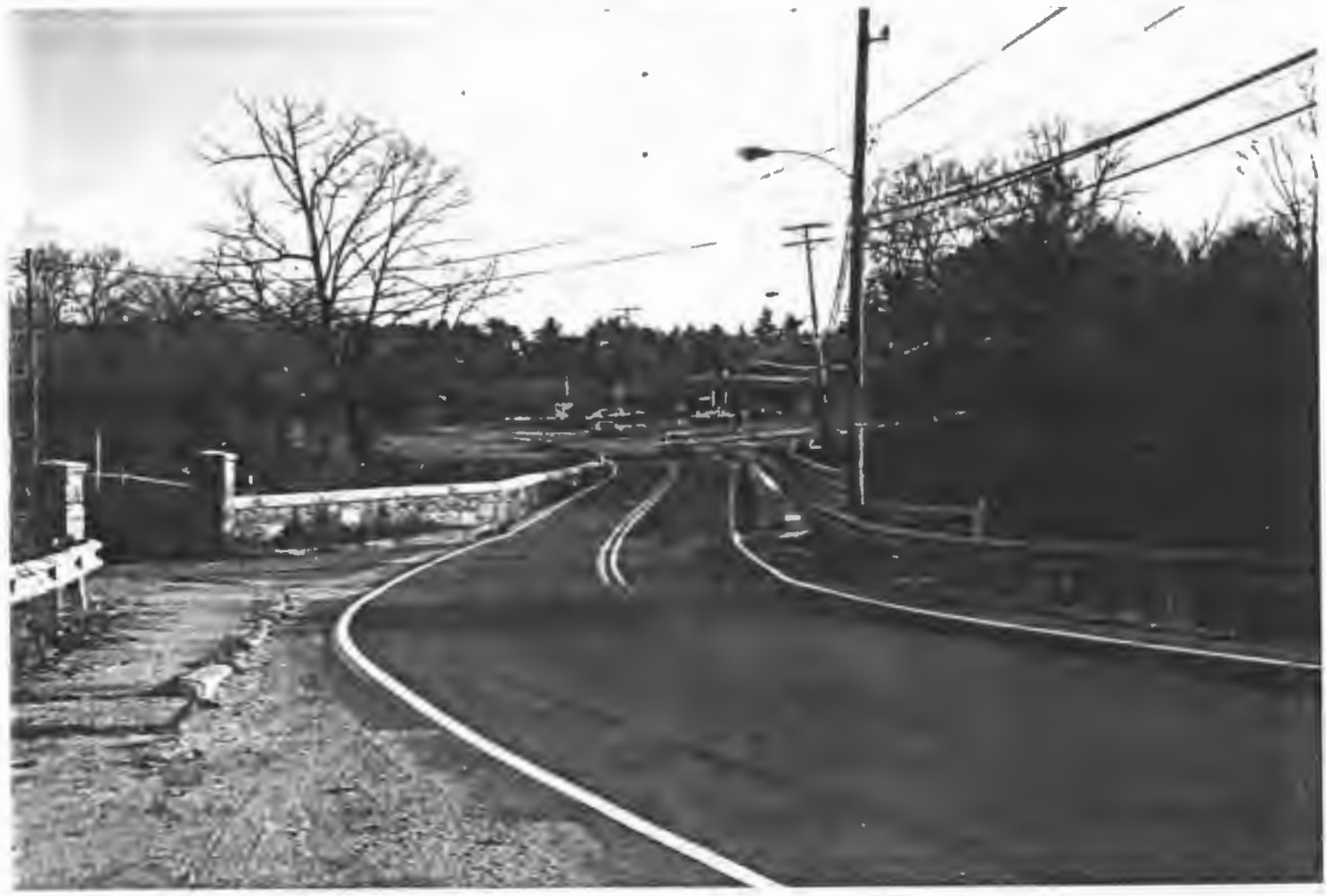


located on Route 5 (Providence Pike and Railroad street), spanning the Branch River. This bridge is of concernbecause of its limited width ( 20 feet) and 10 ton weight limit. Also of concern is the sharp and steep hairpin turn which is encountered when either turning from Main street, North Main Street or School Street to Route 5 (Providence Pike and Railroad Street) or the converse.

Patron parking within the study area, with the exception of the Library, is sparse and poorly marked. Figure 3.11 shows the parking provided for the Fleet building and the Town Hall. Town

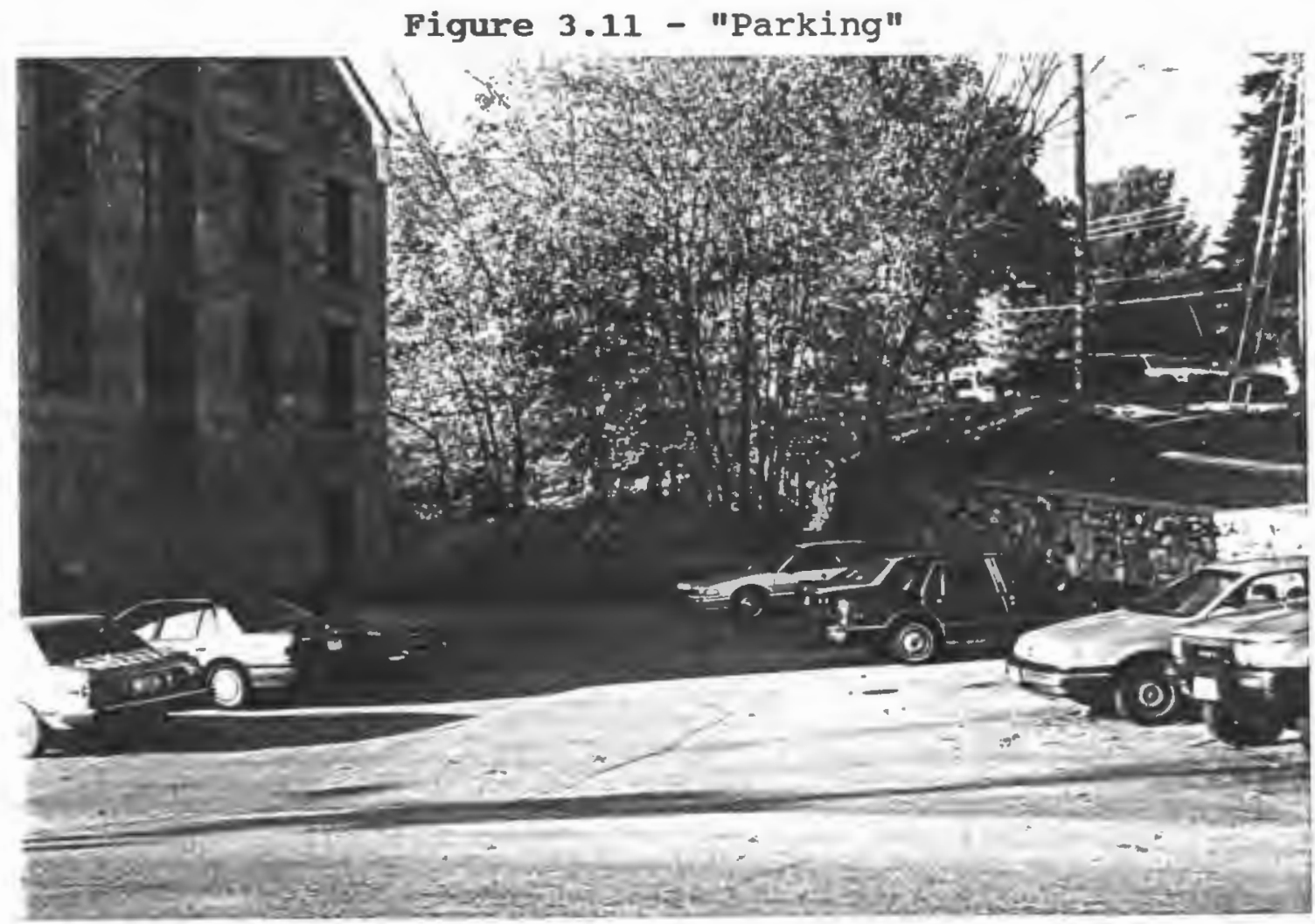


Hall also has upper parking, approximately 6 spaces. Any redevelopment of the study area would surely need to address the present parking situation. It is difficult to ascertain the parking adequacy at the Mill Complex, due to the lack of marked parking spaces. Reuse of the Complex will require detailed analysis for each specific use.

\subsection{INFRASTRUCTURE}

The entire study area is serviced by public sewer public water, excluding the Slatersville Mill Complex. Negotiations, between the Town and the Park water company are currently proceeding to accomplish this by extending service across the Stone Arch Bridge, to connect water lines which exist on Main Street and at the industrial park, adjacent to the Mill complex.

\subsection{STREETSCAPE}

The streetscape of slatersville leaves much to be desired in terms of accommodating pedestrians in a friendly and safe atmosphere. Its development as a Mill Village before the times of automobiles, and the areas current dependence on automobiles is greatly to blame for this shortcoming in pedestrian accommodations. In addition to identifying the reason for this functional problem, several other elements will be discussed which relate to the visual appearance of slatersville. 
To begin, the streets which traverse slatersville are narrow and winding. Sidewalks are either non-existent or in extremely poor condition and directly adjacent to the lane of traffic, with no more than curbing separating the two (Figures $3.12,3.13$,

3.14). Directly across from Town Hall there no sidewalks, and a guardrail forces pedestrians into the street (Figure 3.15). Site distance (Figures $3.16,3.17$ ) in both directions is poor due to the curve in the road. The Existing Conditions Map (Map 3.1) locates existing sidewalks and crosswalks throughout the study area, including the Park area. Figure 3.18 shows the poor condition of the sidewalk adjacent to Margaret Carroll Park. It should be noted that the Mill complex is currently fenced and gated. Pedestrian linkages within the complex are also shown on the map.

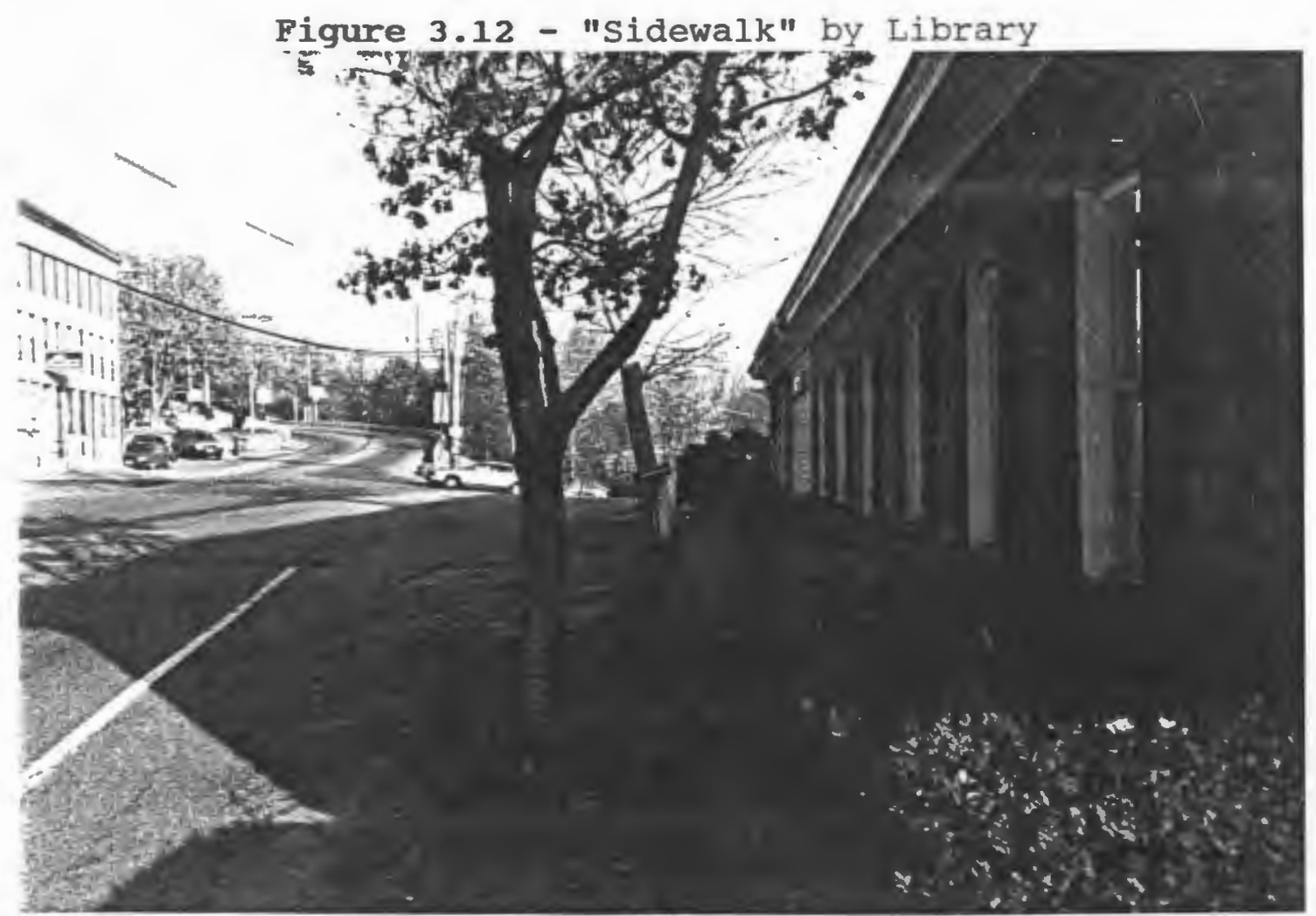




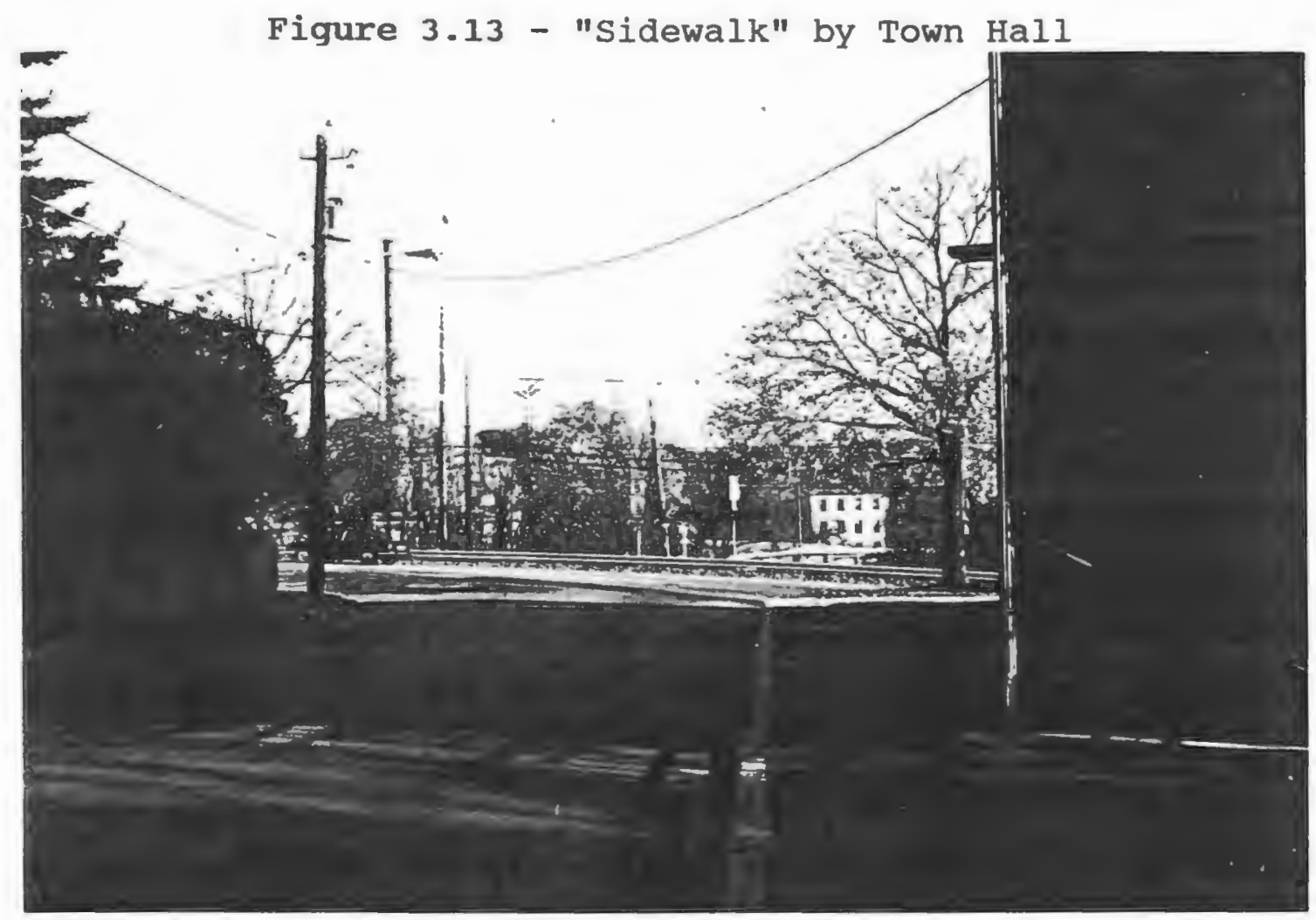

Figure 3.14 - "Sidewalk" between Library and Post Office

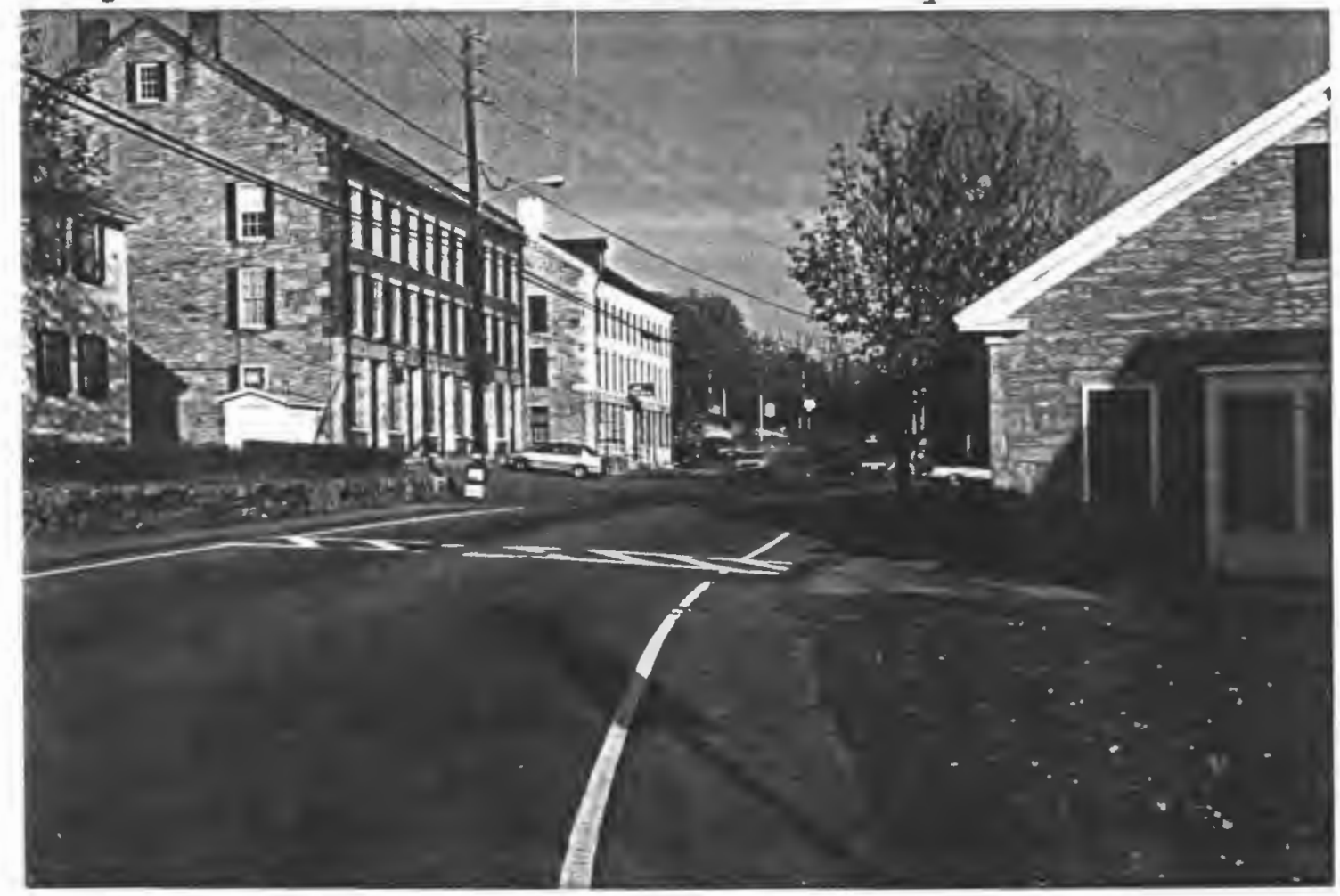


Figure 3.15 - "Guardrail" along Main Street

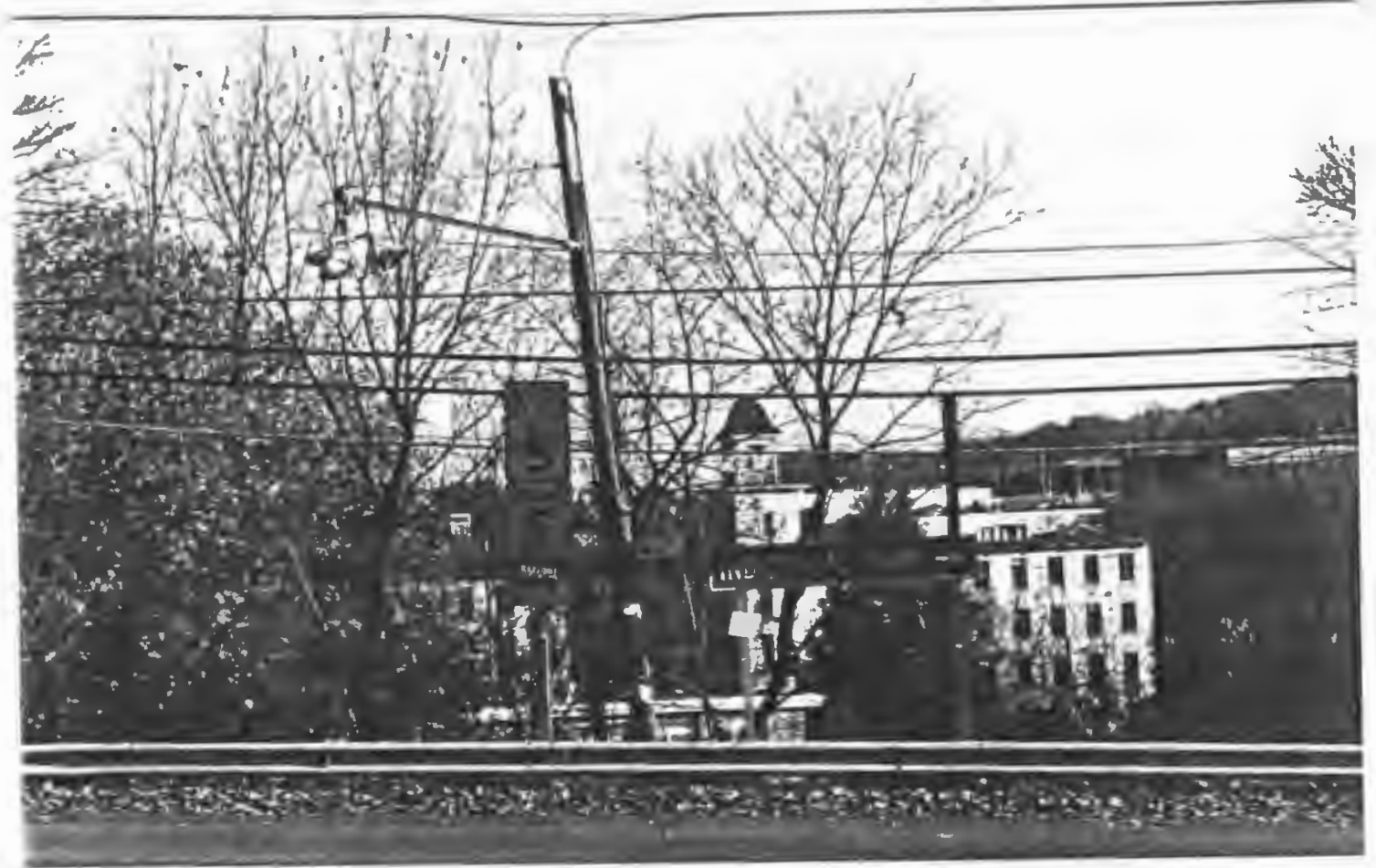

Figure 3.16 - "Site Distance" East from Crosswalk

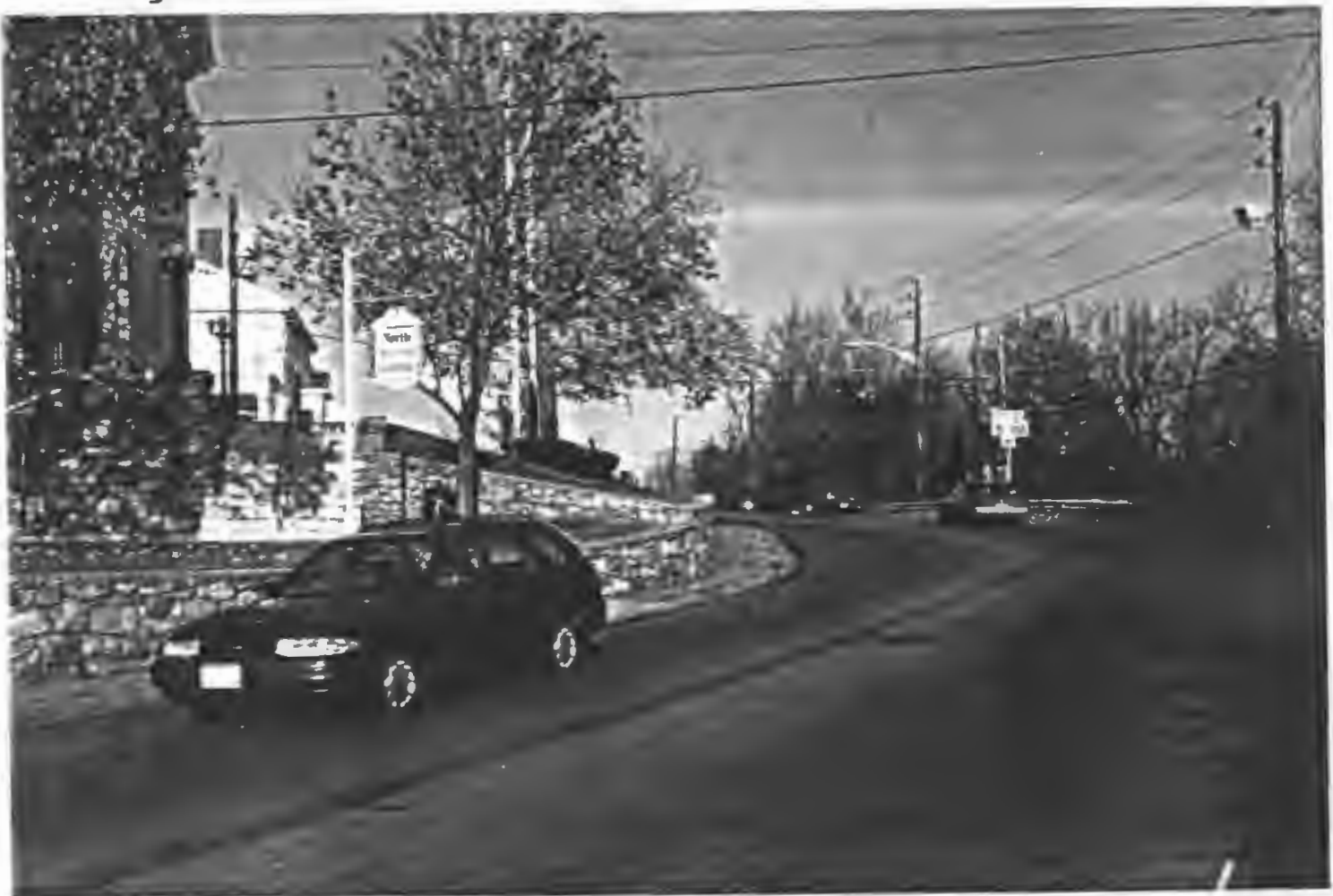


Figure 3.17 - "Site Distance" West from Town Hall

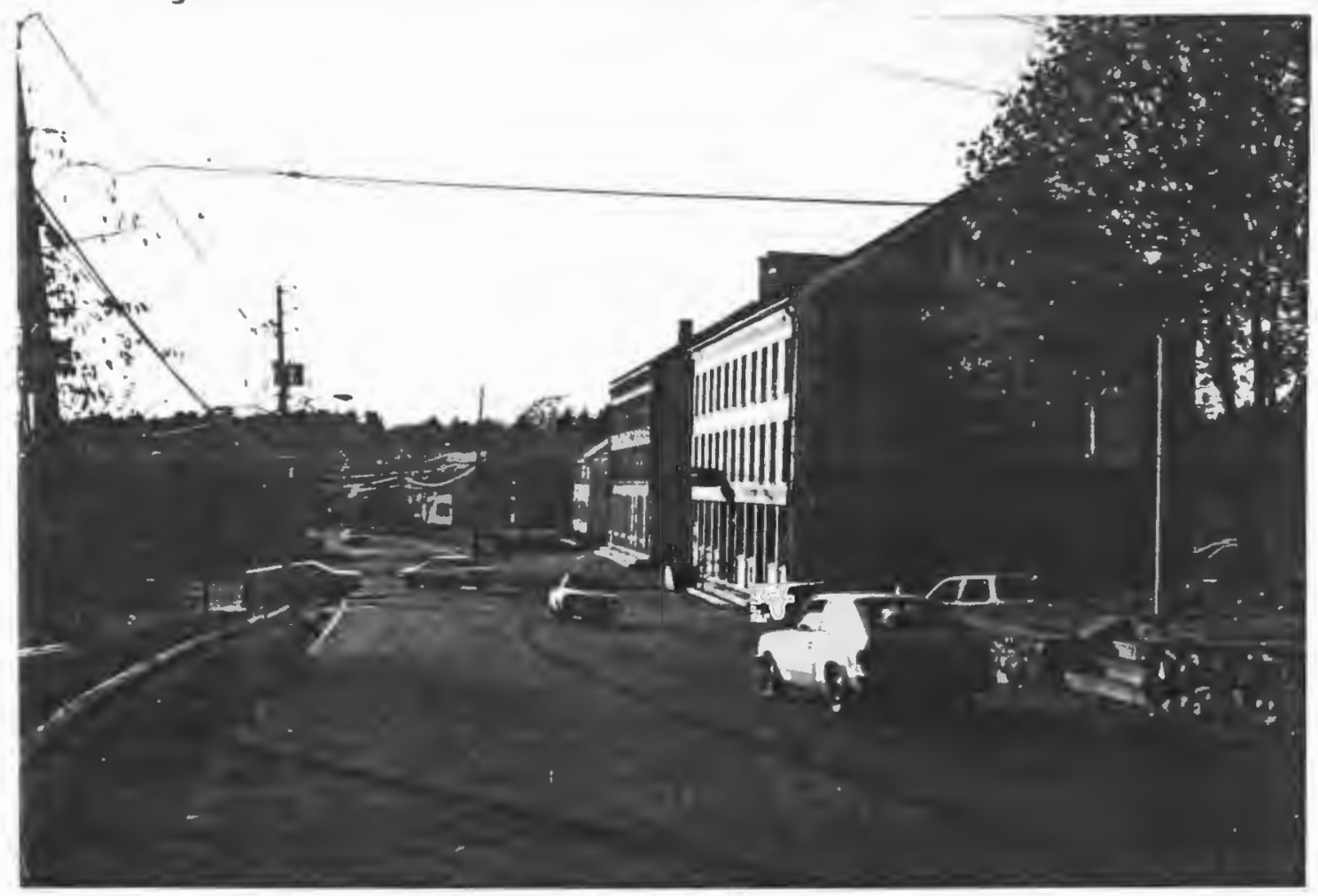

Figure 3.18 - "Sidewalk" by Park

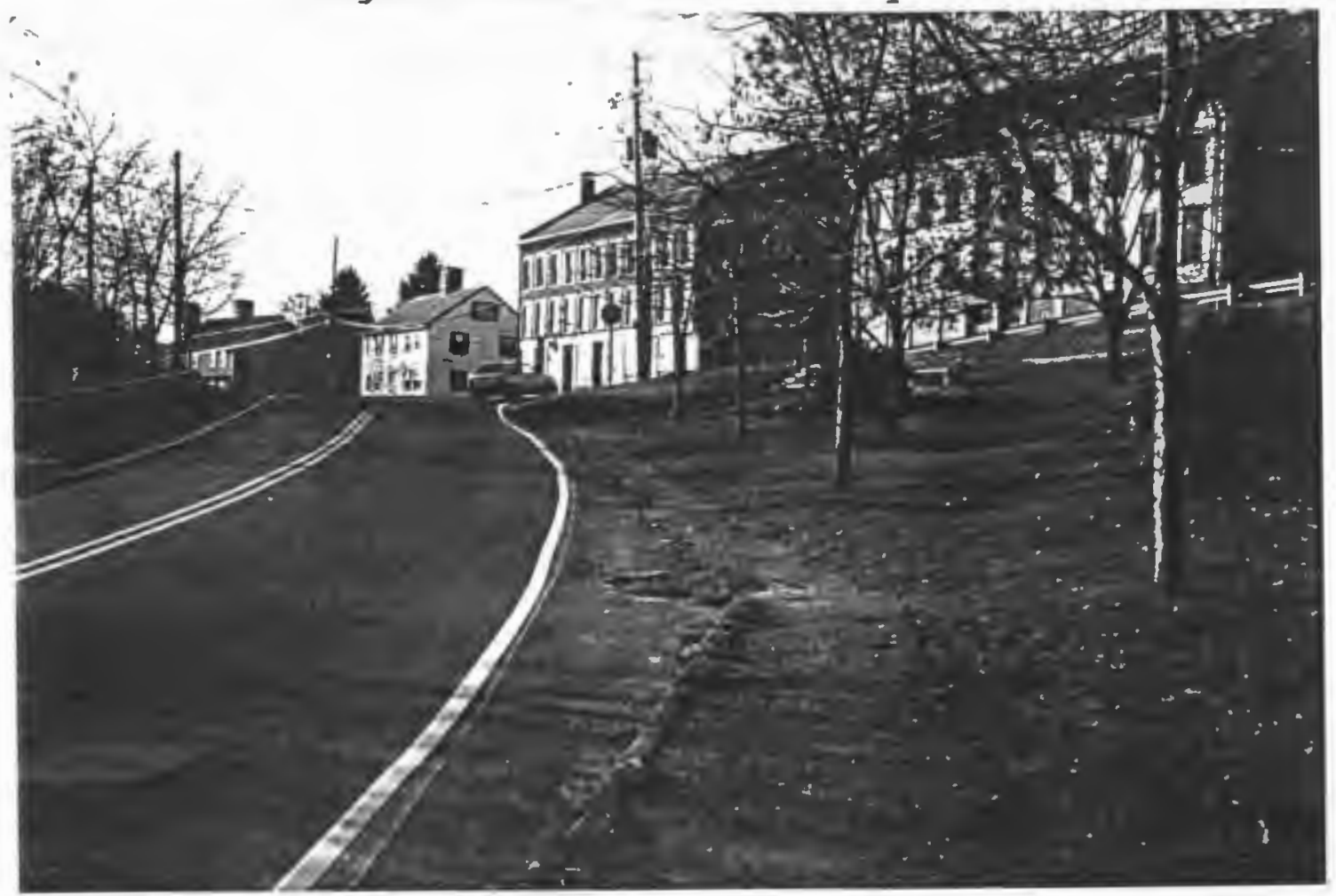


Crosswalks (Figure 3.19) are few and poorly marked. Currently there is one crosswalk from the Fleet National Bank commercial building to the stairs leading through the small triangular shaped park maintained by the North Smithfield Garden club. These stairs connect to a sidewalk which ends at the first entrance to the mill complex.

\section{Figure 3.19 - "Crosswalk"}

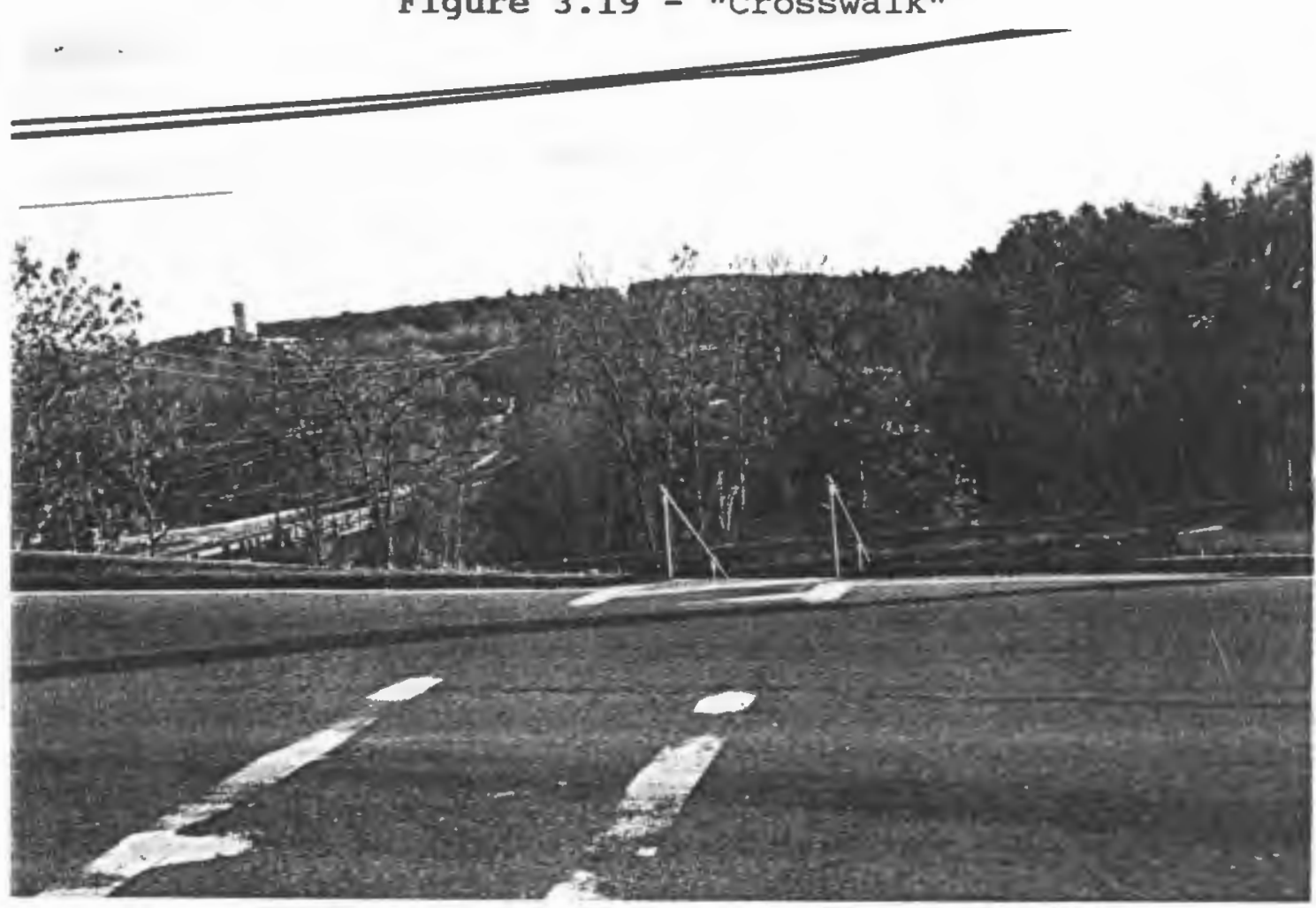

Street trees can be an amenity which add to the pedestrian environment as well as the beautification of an area. Street trees are generally placed in a linear fashion between the sidewalk and the street, on a planting strip. There are no trees meeting this description within the study area.

Street lights exist within the study area and are typical highway street lights; not antique reproductions or decorative in 
nature.

Two park benches (Figure 3.20) exists in the small triangular park at the intersection of Route 5 (Providence Pike and Railroad Street). From observation, it does not appear to be frequently used, most likely because of the heavy flow of traffic surrounding it and the condition of current pedestrian amenities available.

Figure 3.20 - "Park with benches"

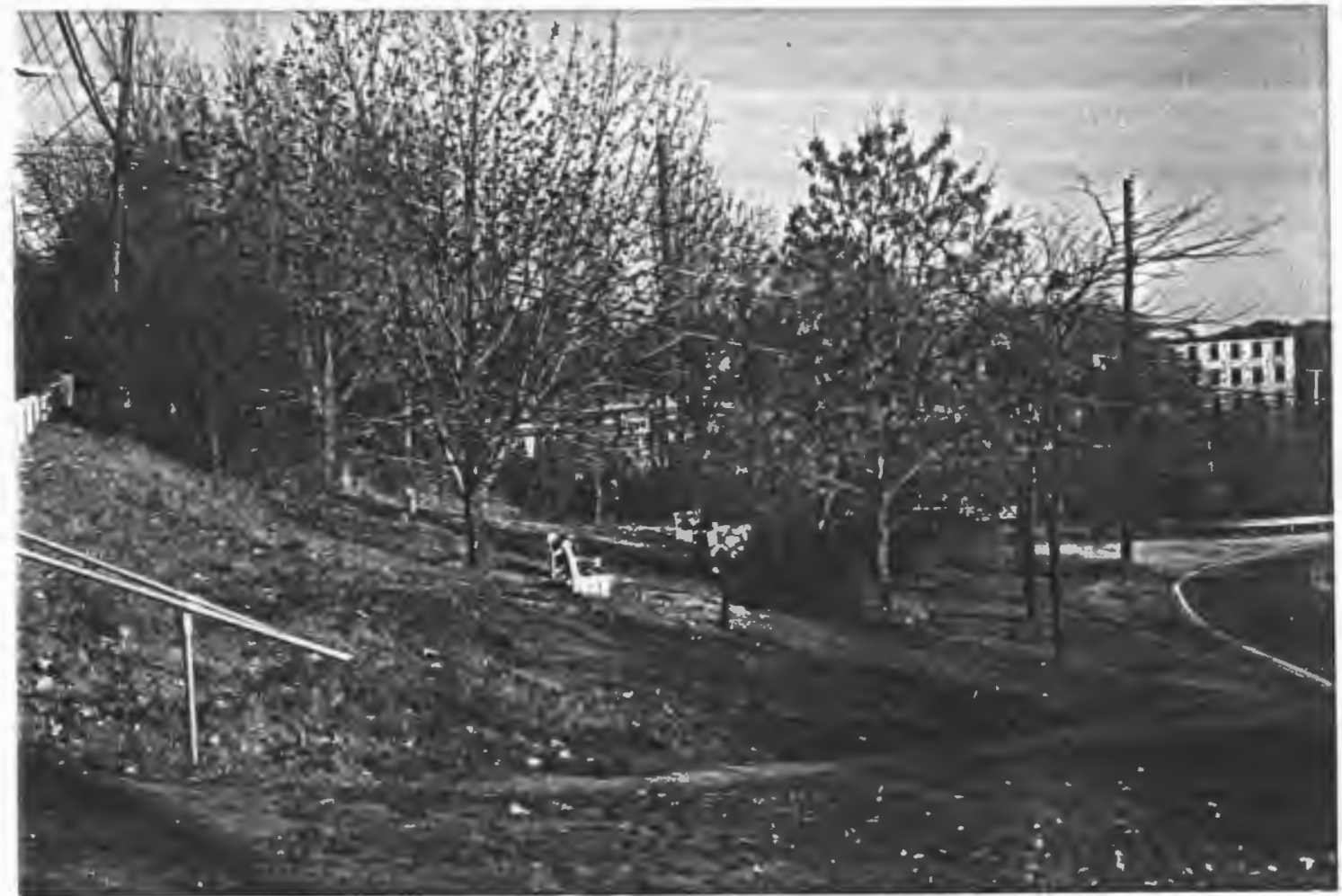

\subsection{SUMMARY OF FINDINGS}

\subsubsection{Existing Plans Relating to Slatersville}

It appears that the existing plans relating to slatersville only serve to preserve and enhance the tremendous resources which Slatersville has to offer. The plans generated from the 
designation of Slatersville being within the Blackstone River Valley National Heritage Corridor seem to capitalize on four elements; history, economic development, natural environment and tourism.

The linear park seems to be a benefit in terms of tourism and drawing people to slatersville. The plan emphasizes the extraordinary historic resources as well as the utilizing wonderful Blackstone and Branch Rivers as places for recreation, region wide. The economic assessment for the entire valley highlights slatersville as an area of special interest for developing visitor attraction materials which will hopefully generate tourism and therefore economic development.

All of this material will be consistent and compatible with this Guide Plan and will be encouraged within the perimeter of this document.

\subsubsection{Building Inventory}

The existing land use of the study area seems to appropriate for buildings which are occupied, but not necessarily the best use for drawing and keeping people in slatersville. It appears that the majority of the study area is underutilized.

The commercial buildings are not being used nearly to full capacity, where the western building is ready for occupancy but not fully occupied and Fleet's commercial building, does not utilize the entire building, and much of it is not currently rehabilitated for use. The Town Hall building is currently at full capacity, but is looking to either expand to a nearby 
facility or move all the town offices to one larger location. The park is severely underutilized and upkeep is poor. The Slatersville Mill Complex is currently vacant and has been so over a year. For many years, the upkeep on this property has been poor, as was housekeeping. This site is a landmark for Slatersville and a focal point for the study area. This complex has great potential and should be the focus of the redevelopment plan for slatersville.

\subsubsection{Zoning}

Regarding the redevelopment of historic structures, it is the opinion of local authorities, ${ }^{26}$ that traditional zoning must be "relaxed" in order to accommodate and encourage viable redevelopment. Many of the old structures do not conform to either the dimensional regulations or the other regulations pertaining to contemporarybuildings of similar use, such as parking, access, as well as fire and building code regulations. In addition, the zones which the historic structures within the study area are located do not accommodate mixed uses which encourage innovative uses of larger older buildings. For example, the mill complex site (zoned Manufacturing) does not allow residential uses. An example of mixed use could include service type facilities on the first floor, office space on the second floor and apartments on the third floor. This scenario could be used in either the commercial buildings or the buildings

26 John Mullen, University of Massachusetts, Regional Planning Department 
in the mill complex. A benefit of mixed use which utilizes the residential component is that a 24-hour use of a site exists, where a building or complex which has only office or just residential is only used a portion of the day. Mixed use makes for a more vital neighborhood or community.

\subsubsection{Circulation}

The historic background of slatersville is evident in the circulation systems serving the study area. The narrow and winding roads reflect a time when automobiles were not needed. Two limitations regarding circulation of the study area are the Stone Arch Bridge and the sloping hairpin turn at the intersection of Route 5 (Providence Pike and Railroad Street) and Main Street. The Stone Arch Bridge has a 10 ton weight limit, and the hairpin turn makes it hard for trucks to turn to the east from Route 5 and south from School street.

\subsubsection{Infrastructure}

Public sewer is available to the entire study area, and public water is available to the entire study area except the Slatersville Mill Complex. Discussions with the Industrial Park Water company indicates that discussions are occurring to connect the water lines across the Stone Arch Bridge to supply the mill complex with public water. This will greatly expand the uses which are possible at this site (ie: multi-family housing; public water a requirement of zoning). 


\subsubsection{Streetscape}

The streetscape is in need of much improvement in terms of accommodating pedestrians and improving the visual appearance of the study area. Elements in need of qualitiative and

quantitative improvement include; sidewalks, signage, streetlights, benches, and crosswalks, both quality and quantity. 


\section{CHAPTER 4 \\ INTRODUCTION TO THE GUIDE PLAN}

The Guide Plan for the Redevelopment of Slatersville includes Goals, Objectives, and Proposals in this Chapter and Implementation strategies for redevelopment of slatersville in the next chapter. The summary of findings in chapter 3 brings to light the major issues facing the study area. These issues are elaborated upon within this chapter and assist in the development of Goals, Objectives, Proposals and Implementation strategies for the study area.

\subsection{GUIDE PLAN DEVELOPMENT}

The Slatersville area has been recognized in the North Smithfield Comprehensive $\mathrm{Plan}$ as an area of potential economic development, recreation, historic and cultural preservation. With this recognition has come the recommendation for a study such as this. The important findings of this study have facilitated the identification of goals, objectives, proposals and finally implementation strategies, all consistent with statewide and region-wide plans and programs. These elements comprise the "Guide Plan" and will be detailed in the next two chapters. These goals, objectives, and proposals not only recognize the need for this study but also give some direction in terms of strategy for implementation. The goals, objectives, proposals, and implementation strategies within this guide plan draw upon, 
dovetail and greatly expanded upon the local and regional plans for the area. They advocate a true sense of direction which slatersville should follow in the future. Most of the goals, objectives, proposals, and implementation strategies found within this Guide Plan have been developed expressly for this study and are site specific in terms of recommendations. Invariably the goals, objectives, and recommendations of this Guide Plan occasionally depict those of the North Smithfield Comprehensive Plan. This reflects the consistency of this Guide Plan to local desires.

The major issues identified in the summary of Findings of the previous chapter are:

1) Cultural Heritage;

2) Significant Historic Resources;

3) Underutilized Recreation;

4) Economic Development Potential;

5) Zoning;

6) Constrained Circulation;

7) Infrastructure;

8) Poor streetscape.

\subsection{PRIMARY ISSUES FACING THE STUDY AREA}

Each issue will now be discussed and defined individually along with their importance to the redevelopment of slatersville. 4.2.1 Cultural Heritage Slatersville cultural heritage is nationally significant, 
but also has state and local significance. Nationally and regionally, the Blackstone River valley was the birthplace of the American industrial revolution and it represents the first widespread industrial use of water power in the United States. In addition it is where the Rhode Island system of Manufacturing was developed. ${ }^{27}$ Slatersville, formerly developed as a company town in the early $1800^{\prime}$ s, remained in this social structure until the mid 1900's. All these factors make slatersville culturally significant and this heritage should be preserved.

\subsubsection{Significant Historic Resources}

Because of the available developable land and the lack of development pressures in the recent years, many of slatersville's historic structures have been spared from destruction, either by inappropriate renovation or demolition. Each building in the study area is of historical significance and worthy of preservation to retain the unique harmonious character of the area .

\subsubsection{Underutilized Recreation}

The Library Association's Centennial Park is one of two parks in the study area. The other being the Margaret carroll Park, developed and maintained by the North Smithfield Garden Club. This park is well developed and maintained, however pedestrian access to and from is poor and unsafe. The Library Association's Centennial Park, approximately 1.5 acres is a

27 Cultural Heritage and Land Management Plan for the Blackstone River Valley National Heritage Corridor. BRVNHC Commission and RI State Planning Council. September, 1990. 
wonderful piece of property with views of the reservoir, historical remnants of waterworks and buildings, and is easily accessible.

\subsubsection{Economic Development Potential}

Slatersville has always been a fairly vital place but has fallen into economic stagnation, and underutilization. This is partly due to the most recent tenant of the Mill Complex vacating the premises more than a year ago. Slatersville has a nearby residential population living in the former mill housing. There is ample opportunity for successful utilization of the two commercial buildings into more appropriate neighborhood type business as well as reuse of the mill complex. These are essential elements in the future economic vitality of Slatersville.

\subsubsection{Zoning}

The zoning of the study area will be a vital tool which could either facilitate or hinder the redevelopment process. A careful examination of the existing zoning in the last chapter have lead to some insightful proposals in this chapter while keeping in mind the appropriate goals and objectives of the area. The current zoning must be amended to include a mixed use zone which would be appropriate for the Mill Complex.

\subsubsection{Constrained Circulation}

A critical factor in the redevelopment of the study area will be the circulation system. As discussed in the previous chapter, there are two critical areas in terms of vehicular 
circulation. These include the Stone Arch Bridge and the sharp angle where Railroad Avenue meets Main Street. The Stone Arch Bridge has a weight limit (10 ton) as well as a width limit (two car width, with no shoulder). Both of these factors are limiting for trucks.

\subsubsection{Infrastructure}

Infrastructure is also a vital issue with respect to redevelopment. The most critical issue is supplying public water to the Mill Complex. A second, not quite so pressing, issue is the visual disturbance of the utility wires within slatersville. Although this is not a critical concern, other than aesthetics, it can be addressed within the confines of this study.

\subsubsection{Poor Streetscape}

Streetscape issues are many and may be a hinderance to the redevelopment of the area if not resolved. Some of the issues are a physical hinderance and others are a matter of visual appearance. These include: poor or lack of sidewalks; street lights which are not in keeping with the historic character of the area; poorly marked crosswalks, lack of street trees to provide a visual definition to the area for pedestrians as well as motorists; and lack of adequate signage to many elements of the study area. 
CHAPTER 5

\section{GOAIS, OBJECTIVES, PROPOSAIS AND IMPIEMENTATION STRATEGIES OF THE GUIDE PLAN}

The goals, objectives, proposals and implementation strategies within this chapter are corollary to the issues identified in the summary of Findings of Chapter 3 and the Major Issues identified in Chapter 4. The Comprehensive Plan discusses Slatersville largely within the Economic Development, Cultural Resources and Blackstone River Valley National Heritage Corridor elements of the Plan. This chapter will address these elements, as well as the other important issues identified in chapter 4, with site specific goals, objectives, proposals, and strategies for implementation.

Each issue will be discussed in terms of goals, objectives and recommended proposals to remedy the situation, along with how to implement the proposals suggested. The Blackstone River Valley National Heritage Corridor Commission espouses that the entire Heritage corridor has significant historic, cultural, and natural resources and, as such, has the potential for renewed economic development, continued historic preservation, recreational recognition and development, and tourism. Overlap in goals, objectives and proposals are inevitable between the eight issues. This will lend coherence and strength to this 
Guide Plan. It should be noted that all the goals, objectives and proposals found within this chapter are consistent with the local, regional and state goals and objectives for slatersville.

The Implementation strategies in this Chapter will identify the actions necessary to carry out the Guide Plan Recommendations. The Implementation strategies take three forms: Legislative; Financial; and Administrative. In addition, some recommendations will require further study before a solution or implementation strategy can be sought. Although this study is comprehensive in nature, finding a solution to every issue identified is not within its realm. It should be recognized that hasty decision making or "quick fix" implementation may not render the best solution for slatersville. Therefore, in some instances, the action of further study is recognized as an implementation strategy within this study.

The Implementation strategies will be discussed by issue, so that continuity may be reached regarding goals, objectives, recommendations, and implementation strategies of the Guide Plan. The Town is currently providing the forum for which to develop this Guide Plan as well as the necessary public advocacy which will be necessary to revitalize the area. This has been and will continue to be a crucial role of the Town in the revitalization process. A final set of tables, organized by issue, is provided as a summary in the following chaper. 


\subsection{GOALS, OBJECTIVES AND PROPOSALS}

\subsubsection{Cultural Heritage}

Goals

1) Create a Cultural Resource Protection Strategy.

2) Encourage appropriate rehabilitation or adaptive reuse for buildings and areas of cultural significance as a protective measure.

3) Integrate cultural planning and development with programs for the revitalization of the Blackstone River Valley National Heritage Corridor.

4) Actively engage in partnership projects which are consistent with goals of the National Heritage corridor.

\section{objectives}

The Comprehensive Plan establishes several Town efforts such as encouraging adaptive reuse for underutilized areas. The Town should link these cultural resources efforts with other town efforts such as protecting existing affordable housing through rehabilitation. In addition slatersville should be used as a case study for North Smithfield in cultural resource enhancement. Slatersville provides the perfect opportunity and has been identified as an area where there is greatest disparity between cultural resources and their protection. Resource protection efforts should use as many protection tools as necessary to provide the greatest protection.

In order to effectively develop a Cultural Resource Strategy, the Town must involve a broad set of "players" and 
people early on, in order to educate them to the purposes of the cultural protection actions. This will help to build a constituency critical for effective implementation.

In addition to creating new cultural Resource efforts, the Town should continue to support established, local efforts to protect historic, cultural and natural resources.

\section{Proposals}

Improved signing is needed for the Library Associations' Centennial Park. In addition it needs rehabilitation and improved regular maintenance.

Improved pedestrian accessibility in slatersville would encourage usage of the resources available. Pedestrian accessibility should be accomplished with a streetscape improvement program which includes pedestrian crossings marked on the pavement.

The current talks now taking place with the slatersville Mill owners as to their future plans for the mill buildings and property should continue. In addition the idea of establishing a mixed use zone for the property should be encouraged, including, but not limited to residential, office, commercial, and incubator uses.

The Town should continue cooperation with regional efforts to promote slatersville as a cultural tourist attraction by providing technical assistance and local knowledge. Such regional efforts include those prompted by the Blackstone River Valley National Heritage Corridor. 


\subsubsection{Significant Historic Resources}

Goals

1) Properties should be preserved in-place, if possible, through affirmative treatments like rehabilitation or passive treatments such as avoidance. ${ }^{28}$

2) Provide the greatest protection possible to slatersvilles' historic resources.

3) Enforce The Secretary of the Interior's standards for Rehabilitation and Guidelines for Rehabilitating Historic Buildings after local historic district designation occurs. 4) Encourage appropriate rehabilitation or adaptive reuse for buildings and areas as a protective measure.

5) Actively engage in partnership projects which are consistent with goals of the National Heritage Corridor.

\section{objectives}

Currently the Town has no specific way to protect the historic resources within the study area. In the absence of future historic district zoning or conservation district designation, the Town should be pro-active relative to the reuse of underutilized historically significant privately-owned buildings. This objective would encourage the appropriate reuse of these buildings.

Because of the designation of the local historic district of Union Village, the Town has already adopted the 10 rehabilitation

28 The Rhode Island Historic Preservation Plan. RI Historical Preservation Commission. June 1989. 
standards of the Rhode Island Historic Preservation Commission. These standards should be considered objectives for rehabilitation within the study area and are found within the summary matrix in the final chapter of this Guide Plan.

\section{Proposals}

Specific proposals which will contribute to the preservation and appropriate reuse of the historic buildings within the study area are several. The slatersville Mill Complex is an essential component to the redevelopment of the study area because of its sheer size and its central location. The Town should continue discussions with the slatersville Mill owners as to their future plans for the mill buildings and property and advance the idea of a mixed use designation for the property. The preparation of a feasibility study is recommended to determine the most appropriate reuse of the slatersville Mill Complex buildings.

The Town should remain active during all phases of the planning and renovation of the Mill Complex to insure appropriate renovation and advocate benefits for slatersville residents and visitors.

As was alluded to in chapter 3, the commercial buildings provide ample opportunity for neighborhood retail and service type businesses. The Town should work with the owners of commercial buildings to encourage rehabilitation and insure appropriate renovation for the type of businesses that are allowed by the Neighborhood Business zoning. 


\subsubsection{Underutilized Recreation}

Goals

1) Provide the residents and visitors of Slatersville with developed and passive recreation opportunities.

2) Encourage recreation development and programs which emphasize Valley resources and provide links to other communities.

3) Actively engage in partnership projects which are consistent with goals of the National Heritage Corridor.

4) Encourage recreation development and programs which emphasize Valley resources and provide links to other communities.

5) Collaborate and support the corridor Commission in the establishment of a Greenway along the Blackstone and Branch Rivers.

\section{objectives}

The study area currently has two park areas, one developed and one underutilized because of poor maintenance, pedestrian access and signage. The majority of the Guide Plan objectives relating to recreation, emphasize the underutilization of recreational amenities, but also recognize the future potential of undeveloped property for park use.

The Town should upgrade and maintain the existing parks within the study area for the use of residents and visitors. In addition the Town should take advantage of the Natural Resources of the Branch River for recreation purposes. This will promote the goals of the Blackstone River Valley National Heritage Corridor Commission. 
Whenever possible, utilize and emphasize the cultural remains of old mill structures within park areas; specifically the old water works at the centennial Park.

Proper signage is needed to alert residents and visitors of the area of the existing park areas to encourage greater utilization. This will especially help the out of town tourists but will also help to orient the local residents unfamiliar with Slatersville.

Adequate pedestrian amenities should be an important objective throughout the study area to encourage and provide pedestrian accessibility to park areas.

The Conservation Commission and Parks and Recreation Commission should be assigned to promote land conservation and historic park restoration.

\section{Proposals}

The redevelopment and maintenance of the Library Association's Centennial Park is the first and most essential proposal recommended in order to encourage its full usage and potential. This proposal includes developing permanent cultural on-site information regarding the historical remains at the park.

In addition the Town should determine the feasibility of developing a park on the property behind (east of) the Mill Complex along the north side of the Branch River, that has access from School street.

The Town should work cooperatively with the BRVNHC Commission in developing signage for all parks within the study 
area, to be consistent with the rest of the Blackstone River Valley

A Sidewalk Improvement Program should be developed for Slatersville which links the park facilities to other features in the area.

\subsubsection{Economic Development Potential}

Goals

1) Foster expansion and a diversity of industrial opportunity existing at the Mill Complex to encourage incubator-type uses, while being consistent with historic structures.

2) Encourage redevelopment of Commercial Block in slatersville.

3) Support economic development which compliments goals of the National Heritage Corridor.

4) Actively engage in partnership projects which are consistent with goals of the National Heritage Corridor.

5) Develop an economic development strategy that maintains current manufacturing activities, and targets environmentally sensitive industry and business compatible with historic surroundings.

\section{Objectives}

Infrastructure is a necessary component to redevelopment of the Mill Complex. This area is now serviced by public sewer and there are currently negotiations for the provision of public water to this site. The Town should continue facilitating these discussions and encourage settlement on this issue. The adoption of performance standards for industries locating within the Town 
should be an objective to encourage a variety of uses at the Mill Complex, which may be appropriate but not currently allowed by zoning. This could be accomplished as part of zoning ordinance revisions. The Town should be pro-active in terms of recruiting appropriate uses for the historic buildings within the study area; the Mill Complex, the commercial buildings and the town hall.

A Streetscape Improvement Program will help to improve visual appearance of Slatersville. This will make the area more attractive and should facilitate the attraction of new neighborhood type businesses. This should be accomplished in addition to encouraging local type services in commercial Buildings. This will make errands more convenient to nearby residents while boosting the economic activity in slatersville.

\section{Proposals}

The main economic development proposal is to facilitate in any way, the adaptive reuse of the slatersville Mill site as a Mixed Use development including offices, research and development and housing. The Town's role should include preparing a feasibility study to determine the most appropriate use, both economically and practically, from an engineering standpoint.

Continuation of the public private partnership being utilized to prepare this guide plan is also recommended to insure the successful implementation of the reuse of the Mill Complex.

The development of design recommendations and implementation strategies for streetscape improvements is recommended to 
encourage economic development within slatersville.

Another key proposal is to revise the zoning regulations and districts as proposed in the Land Use Plan Element; consider special provisions for adaptive reuse of older mill structures.

\subsubsection{Zoning}

Goal

Revise zoning ordinance to accommodate the appropriate redevelopment of the historic structures within the study area and the Town.

\section{objectives}

The most important objective for zoning is to provide zoning regulations which are most appropriate to the study area.

As discussed in the previous section, the Zoning Ordinance needs revision of its regulations and districts to consider special provisions for adaptive reuse of older mill structures. This is also suggested in the Land Use Plan Element of the Comprehensive Plan.

\section{Proposals}

Determine feasibility of zoning the property behind (east of) the Mill Complex and North of Branch River to allow for recreation and/or open space.

In addition provide for the necessary changes in the zoning Ordinance to allow a mix of uses at the slatersville Mill Complex. 


\subsubsection{Constrained circulation}

Goal

Provide the best possible circulation and parking throughout the study area and slatersville, taking into consideration and retaining, the area's significance as a historic mill village.

\section{objectives}

The objectives for circulation encompass three issues; automobile, parking, and biking. The Town should continue to take a pro-active role in local transportation and DOT projects to insure that historic, cultural and natural features are considered in the design. This is a crucial issue when considering the redesign of the Stone Arch Bridge.

Determine if the current parking within the study area is adequate for full redevelopment scenario.

The Town should support the bikeway as an alternative transportation route as well as a recreational/educational feature within slatersville.

\section{Proposals}

The Town currently does and should maintain close relations with the state Historic Preservation Commission and request their involvement in all circulation improvements as an advocate to maintaining historic character with respect to circulation features.

In addition a parking analysis for the study area is recommended to determine if available parking will constrain future uses of the individual sites. 


\subsubsection{Infrastructure}

Goal

Provide necessary infrastructure to study area which allows development commensurate with other goals.

objectives

The most pressing objective with respect to infrastructure and redevelopment of the study area is to insure public water to the Study Area.

Any future infrastructure improvements should include placing the electrical wires underground. This would provide more aesthetically attractive electrical service within Slatersville.

\section{Proposals}

The Town should continue to facilitate cooperation with Mill Complex owners to insure adequate infrastructure facilities for its redevelopment.

Blackstone Valley Electric should be contacted to develop a program for providing underground utilities within the study area in compliance with Statewide Planning Transportation Improvement Program (TIP). The funding for such a program could come from TIP, which is funded from the Intermodal surface Transportation Efficiency Act (ISTEA).

\subsubsection{Poor Streetscape}

Goal

Provide a streetscape within the study area which encourages safe pedestrian activity, economic development, tourism, and 
historic visual appearance.

objectives

Objectives to improve the currently poor streetscape within the study area include improving pedestrian accessibility and safety while improving visual appearance of the study area. The potential for economic activity should be considered when developing a streetscape Improvement Program.

Proposals

Develop a streetscape Improvement Program with special attention to pedestrian crossings which are marked on the pavement.

Develop Streetscape Design Guidelines which are harmonious with the historic and cultural character of slatersville. These should be carried out by the Town Planner and enforced by the zoning and building inspector.

\subsection{IMPLEMENTATION STRATEGIES}

\subsubsection{Cultural Heritage}

The preparation of a Cultural Resource Protection Program is necessary to fulfill many of the proposals suggested in the preceding section. This Program should utilize, but not be limited to, the following tools for protection: Regulation, National Register of Historic Places Nomination, Grant Monies, Economic Development and Tourism.

It is recommended in the North Smithfield Comprehensive Plan 
that slatersville be the initial focus of such a program. ${ }^{29}$ Focusing efforts will achieve more effective results and persuade the residents of the Town that the program can work.

Financial strategies include using grant monies from grant applications to achieve many of the recommendations of the Cultural Resource Protection Program. Such funding sources include the RI Historical Preservation Commission, the RI Committee on the Humanities, Community Development Block Grants (CDBG), and private foundation grants. CDBG's fund such elements as feasibility studies, streetscape improvements and historic and housing rehabilitation. The RI Historical Preservation Commission Grants fund such elements as inventorying cultural resources which are insufficiently documented. The RI committee on the Humanities funds educational projects.

\subsubsection{Significant Historic Resources}

Historic District zoning should be seriously considered as a regulatory tool available to protect historic and cultural resources. Its benefits should be carefully evaluated in areas where a major adaptive reuse is contemplated as with the Slatersville Mill Complex. Adopt zoning ordinance provisions involving cultural and historic resource protection, such as overlay zoning for areas in need of an extra layer of protection such as slatersville. In addition, North Smithfield should

29 "Of the cultural resource areas in North Smithfield, slatersville has the greatest gap between the significance of its resources and the level of their protection." Comprehensive Plan. 1991 . 
initiate discussion with the Blackstone River Valley National Heritage Corridor Commission regarding the creation of a model ordinance for preserving cultural and historical resources common in the Blackstone River Valley.

\subsubsection{Underutilized Recreation}

Community Development Block Grants and other funding as discussed above may be used to accomplish several of the proposals identified in Table 4.3. These include: "redevelop and maintain the Library Association's Centennial Park to its full potential"; "determine feasibility of developing a park on the property behind (east of) the Mill Complex along the north side of the Branch River, with access from School street"; and "develop a streetscape Improvement Program". This will include providing signage and pedestrian linkage to recreation resources.

\subsubsection{Economic Development Potential}

The Slatersville Mill Complex has strong potential for economic development. Several factors warrant a feasibility study for this property. The site has not had much upkeep in the recent past and some of the buildings will need extensive renovation to make them usable for any use. Not only are the buildings unique in size and shape, but they probably do not meet the existing building codes. In addition, they are within the National and State Historic District, and possibly soon to be within a local Historic District. This designation places facade renovation restrictions, in addition to the factors of uniqueness and the outdated nature of the buildings. For this reason, a 
feasibility study is necessary to determine the best and most feasible use for these buildings so that when the buildings are adapted, the use will be successful and prosperous. The Feasibility study should address four key areas: market support and economic evaluation; site and locational characteristics; structural considerations; and architectural and historical aspects.

It is anticipated that a new zone will need to be created to allow for successful adaptive reuse of this complex and the commercial block within slatersville. This new zone will include either performance standards within the Manufacturing zone or a new district allowing mixed use. This flexibility will allow for more varied uses, compatible with the surrounding area.

It should be recognized that very few uses can occur at the Mill Complex without the provision of public water. This linkage across the Stone Arch Bridge is essential, whether accomplished by the Town or the Mill Complex owners.

slatersville has a lot to offer to visitors in terms of cultural and historic resources. The Blackstone River Valley National Historic Corridor Commission is the ideal vehicle to promote and encourage tourism for this purpose. This will enhance economic development within the area.

\section{2 .5 Zoning}

Changing or updating the zoning ordinance is a method of implementation which would allow more appropriate uses within the study area as permitted uses. This implementation strategy will 
facilitate the redevelopment process within the study area.

\subsubsection{Constrained Circulation}

Several strategies are necessary to successfully promote Economic Development and Tourism in Slatersville. These include adequate parking and signage. These elements should be provided through implementation of the parking analysis recommendations and execution of the Streetscape Improvement Program which will provide necessary signage for the study area.

\subsubsection{Infrastructure}

It appears that the only element lacking in terms of infrastructure is public water to the Mill complex. This can be accomplished by providing a linkage across the Stone Arch Bridge connecting water on Main street with water supplied to the Industrial Park, just south of the Mill Complex. This can be achieved either by the Town or through a public/private negotiation.

\subsubsection{Poor Streetscape}

Implementation of a streetscape Improvement Program which includes Streetscape Design Guidelines will alleviate the poor streetscape which was described in the "Existing Conditions" chapter. Implementation of this program will help to increase the potential of slatersville for tourism and economic development. Funding for this program may come from a community Development Block Grant application. 


\section{CHAPTER 6 \\ CONCIUSION}

\subsection{SUMMARY OF FINDINGS}

Tables 6.1 through 6.8 shows the issues broken down into the proposed goals, objectives, proposals and implementation strategies. The issue is presented at the top of each table and followed by subsequent goals, objectives, proposals and implementation strategies. It should be noted that items prefaced by an asterisk (*) are embraced within the North Smithfield Comprehensive Plan and therefore are consistent with this Guide Plan. Some of these items may have been changed slightly to reflect the local focus of this study and its goals, objectives and proposals. Goals, Objectives, Proposals and Implementation Strategies without an asterisk (*) are developed specifically for this Guide Plan and are compatible with all National, state and local programs and policies which currently exist. 
TABLE 6.1

CULTURAL HERITAGE

\begin{tabular}{|c|c|c|c|}
\hline Goal & objective & Proposal & Implementation \\
\hline $\begin{array}{l}\text { * Create a cultural } \\
\text { Resource Protection } \\
\text { Strategy. } \\
\text { * Encourage } \\
\text { appropriate } \\
\text { rehabilitation or } \\
\text { adaptive reuse for } \\
\text { buildings and areas } \\
\text { of cultural } \\
\text { significance as a } \\
\text { protective measure. } \\
\text { * Integrate cultural } \\
\text { planning and } \\
\text { development with } \\
\text { programs for the } \\
\text { revitalization of } \\
\text { the Blackstone River } \\
\text { Valley National } \\
\text { Heritage corridor. }\end{array}$ & $\begin{array}{l}\text { * Use Slatersville } \\
\text { as a case study for } \\
\text { North Smithfield in } \\
\text { cultural resource } \\
\text { enhancement. } \\
\text { * Link cultural } \\
\text { resources effort } \\
\text { with other town } \\
\text { efforts, such as: } \\
\text { encouraging adaptive } \\
\text { reuse for } \\
\text { underutilized areas; } \\
\text { protecting existing } \\
\text { affordable housing } \\
\text { through rehabilita- } \\
\text { tion; and upgrading } \\
\text { pedestrian } \\
\text { amenities. }\end{array}$ & $\begin{array}{l}\text { * Improve signing } \\
\text { for the Library } \\
\text { Assoc.'s centennial } \\
\text { Park. It needs } \\
\text { rehabilitation and } \\
\text { improved maintenance } \\
\text { as well as } \\
\text { appropriate signing. } \\
\text { * Improve pedestrian } \\
\text { accessibility in } \\
\text { Slatersville with a } \\
\text { streetscape improve- } \\
\text { ment program and } \\
\text { pedestrian crossings } \\
\text { marked on pavement. }\end{array}$ & $\begin{array}{l}\text { Prepare a Cultural } \\
\text { Resource Protection } \\
\text { Program. } \\
\text { Use Community } \\
\text { Development Block } \\
\text { Grants (CDBG) funds } \\
\text { through grant } \\
\text { applications for } \\
\text { implementation of } \\
\text { program } \\
\text { recommendations. } \\
\text { Use grants from the } \\
\text { RI Historical } \\
\text { Preservation } \\
\text { Commission and RI } \\
\text { Committee on the } \\
\text { Humanities to } \\
\text { implement program } \\
\text { recommendations. }\end{array}$ \\
\hline
\end{tabular}


TABLE 6.1 (con't)

CULTURAL HERITAGE

\begin{tabular}{|c|c|c|c|}
\hline Goal & objective & Proposal & Implementation \\
\hline $\begin{array}{l}\text { * Actively engage in } \\
\text { partnership projects } \\
\text { which are consistent } \\
\text { with goals of the } \\
\text { National Heritage } \\
\text { Corridor. }\end{array}$ & $\begin{array}{l}\text { * Use as many } \\
\text { protection tools as } \\
\text { necessary to provide } \\
\text { the greatest } \\
\text { protection. } \\
\text { * Involve a broad } \\
\text { set of "players" and } \\
\text { people early on, in } \\
\text { order to educate } \\
\text { them to the purposes } \\
\text { of the actions and } \\
\text { build a constituency } \\
\text { critical for } \\
\text { effective } \\
\text { implementation. } \\
\text { * continue to } \\
\text { support established, } \\
\text { local efforts to } \\
\text { protect historic, } \\
\text { cultural and natural } \\
\text { resources. }\end{array}$ & $\begin{array}{l}\text { * Continue talks } \\
\text { with the } \\
\text { slatersville Mill } \\
\text { owners as to their } \\
\text { future plans for the } \\
\text { mill buildings and } \\
\text { property and advance } \\
\text { the idea of mixed } \\
\text { use for the } \\
\text { property. } \\
\text { Cooperate with } \\
\text { regional efforts to } \\
\text { promote slatersville } \\
\text { as a cultural } \\
\text { tourist attraction } \\
\text { by providing } \\
\text { technical assistance } \\
\text { and local knowledge. }\end{array}$ & $\begin{array}{l}\text { Provide for cultural } \\
\text { resource protection } \\
\text { within the Zoning } \\
\text { Ordinance. } \\
\text { Cooperate with the } \\
\text { BRVNHCC in creating } \\
\text { a model ordinance } \\
\text { for cultural } \\
\text { resources common in } \\
\text { the Blackstone } \\
\text { valley. }\end{array}$ \\
\hline
\end{tabular}


TABLE 6.2

SIGNIFICANT HIBTORICAL RBSOURCBS

\begin{tabular}{|c|c|c|c|}
\hline Goa 1 & objective 30 & Proposa 1 & Implementation \\
\hline $\begin{array}{l}\text { Properties should be } \\
\text { preserved in-place, } \\
\text { if possible, through } \\
\text { affirmative treat- } \\
\text { ments like rehab- } \\
\text { ilitation or passive } \\
\text { treatments such as } \\
\text { avoidance. } 31 \\
\text { Provide the greatest } \\
\text { protection possible } \\
\text { to slatersvilles } \\
\text { historic resources. }\end{array}$ & $\begin{array}{l}\text { * Be pro-active } \\
\text { relative to the } \\
\text { reuse of under- } \\
\text { utilized historic- } \\
\text { ally significant } \\
\text { privately-owned } \\
\text { buildings. } \\
\text { Insure that the use } \\
\text { determined for the } \\
\text { historic properties } \\
\text { within the study } \\
\text { area require minimal } \\
\text { alteration of the } \\
\text { building, structure, } \\
\text { or site. }\end{array}$ & $\begin{array}{l}\text { * Continue talks } \\
\text { with the } \\
\text { Slatersville Mill } \\
\text { owners as to their } \\
\text { future plans for the } \\
\text { mill buildings and } \\
\text { property and advance } \\
\text { the idea of mixed } \\
\text { use for the } \\
\text { property. } \\
\text { Prepare a Feasi- } \\
\text { bility study to } \\
\text { determine the most } \\
\text { appropriate reuse of } \\
\text { the slatersville } \\
\text { Mill complex } \\
\text { buildings. }\end{array}$ & $\begin{array}{l}\text { Adopt Historic } \\
\text { District Zoning } \\
\text { after careful } \\
\text { evaluation of its } \\
\text { benefits to } \\
\text { slatersville. } \\
\text { Apply for CDBG } \\
\text { monies to prepare } \\
\text { feasibility studies } \\
\text { for reuse of } \\
\text { slatersville Mill } \\
\text { Complex and } \\
\text { Commercial Buildings }\end{array}$ \\
\hline
\end{tabular}

30 Easy Guide to Rehab Standards. RI Historical Preservation Commission. 1992.

31 The Rhode Island Historic Preservation Plan. RI Historical Preservation Commission. June 1989. 
TABLB 6.2 (con't)

SIGNIFICANT HISTORICAL RESOURCES

\begin{tabular}{|c|c|c|c|}
\hline Goal & objective & Proposal & Implementation \\
\hline $\begin{array}{l}\text { Enforce The } \\
\text { Secretary of the } \\
\text { Interior's Standards } \\
\text { for Rehabilitation } \\
\text { and Guidelines for } \\
\text { Rehabilitating } \\
\text { Historic Buildings } \\
\text { after local historic } \\
\text { district designation } \\
\text { occurs. } \\
\text { * Encourage } \\
\text { appropriate } \\
\text { rehabilitation or } \\
\text { adaptive reuse for } \\
\text { buildings and areas } \\
\text { as a protective } \\
\text { measure. }\end{array}$ & $\begin{array}{l}\text { Avoid destroying the } \\
\text { distinguishing } \\
\text { original features of } \\
\text { a building, struc- } \\
\text { ture or site within } \\
\text { the study area. } \\
\text { Avoid building alt- } \\
\text { erations which have } \\
\text { no historical basis. } \\
\text { Retain and preserve } \\
\text { later changes to } \\
\text { historic bldgs. } \\
\text { which have acquired } \\
\text { significance in } \\
\text { their own right. } \\
\text { Deteriorated his- } \\
\text { toric features shall } \\
\text { be repaired rather } \\
\text { than replaced or } \\
\text { replaced with match- } \\
\text { ing feature. }\end{array}$ & $\begin{array}{l}\text { Work with owners of } \\
\text { commercial buildings } \\
\text { to insure approp- } \\
\text { riate renovation. } \\
\text { Continue use of } \\
\text { Community } \\
\text { Development Block } \\
\text { Grant Funds for } \\
\text { rehabilitating } \\
\text { housing. } \\
\text { Town should remain } \\
\text { active during all } \\
\text { phases of the } \\
\text { planning and } \\
\text { renovation of Mill } \\
\text { Complex to insure } \\
\text { appropriate } \\
\text { renovation and } \\
\text { advocate benefits } \\
\text { for slatersville } \\
\text { residents and } \\
\text { visitors. }\end{array}$ & $\begin{array}{l}\text { Establish program or } \\
\text { position for } \\
\text { enforcing historic } \\
\text { rehabilitation } \\
\text { standards. } \\
\text { Provide for historic } \\
\text { resource protection } \\
\text { by ordinance. } \\
\text { Cooperate with the } \\
\text { BRVNHC in creating } \\
\text { a model ordinance } \\
\text { for historic } \\
\text { resources common in } \\
\text { the Blackstone } \\
\text { Valley. }\end{array}$ \\
\hline
\end{tabular}


TABLE $6.2(\operatorname{con} ' t)$

SIGNIFICANT HISTORICAL RESOURCES

\begin{tabular}{|c|c|c|c|}
\hline Goa 1 & objective & Proposal & Implementation \\
\hline $\begin{array}{l}\text { * Actively engage in } \\
\text { partnership projects } \\
\text { which are consistent } \\
\text { with goals of the } \\
\text { National Heritage } \\
\text { Corridor. }\end{array}$ & $\begin{array}{l}\text { Surface cleaning of } \\
\text { structures shall be } \\
\text { undertaken using the } \\
\text { gentlest means } \\
\text { possible. } \\
\text { New additions, ex- } \\
\text { terior alterations, } \\
\text { or related new } \\
\text { construction shall } \\
\text { not destroy historic } \\
\text { materials which } \\
\text { characterize the } \\
\text { property and shall } \\
\text { be compatible. } \\
\text { New additions and } \\
\text { adjacent or related } \\
\text { construction shall } \\
\text { be done, such that } \\
\text { if removed in the } \\
\text { future; the integ- } \\
\text { rity of original } \\
\text { property shall be } \\
\text { unimpaired. }\end{array}$ & & \\
\hline
\end{tabular}


TABLE 6.3

UNDERUTILIZED RBCRBATION

\begin{tabular}{|c|c|c|c|}
\hline Goal & objective & Proposal & Implementation \\
\hline $\begin{array}{l}\text { Provide the resi- } \\
\text { dents and visitors } \\
\text { of Slatersville with } \\
\text { developed and } \\
\text { passive recreation } \\
\text { opportunities. } \\
\text { * Encourage } \\
\text { recreation } \\
\text { development and } \\
\text { programs which } \\
\text { emphasize valley } \\
\text { resources and } \\
\text { provide links to } \\
\text { other communities. } \\
\text { * Actively engage in } \\
\text { partnership projects } \\
\text { which are consistent } \\
\text { with goals of the } \\
\text { National Heritage } \\
\text { Corridor. }\end{array}$ & $\begin{array}{l}\text { Upgrade and maintain } \\
\text { the existing parks } \\
\text { within the study } \\
\text { area for the use of } \\
\text { residents and } \\
\text { visitors. } \\
\text { Take advantage of } \\
\text { the Natural } \\
\text { Resources of the } \\
\text { Branch River for } \\
\text { Recreation purposes. } \\
\text { Whenever possible, } \\
\text { utilize and } \\
\text { emphasize the } \\
\text { cultural remains of } \\
\text { old mill structures } \\
\text { within park areas. }\end{array}$ & $\begin{array}{l}\text { Redevelop and } \\
\text { maintain the Library } \\
\text { Association's } \\
\text { Centennial Park to } \\
\text { its full potential. } \\
\text { Determine } \\
\text { feasibility of } \\
\text { developing a park on } \\
\text { the property behind } \\
\text { (east of) the Mill } \\
\text { Complex along the } \\
\text { north side of the } \\
\text { Branch River, with } \\
\text { access from School } \\
\text { street. } \\
\text { Develop permanent } \\
\text { cultural on-site } \\
\text { information } \\
\text { regarding the } \\
\text { historical remains } \\
\text { at the Centennial } \\
\text { Park. }\end{array}$ & $\begin{array}{l}\text { Initiate discussion } \\
\text { with RI Department } \\
\text { of Environmental } \\
\text { Management to secure } \\
\text { funding for park } \\
\text { development behind } \\
\text { Mill complex as part } \\
\text { of the Linear Park } \\
\text { along the Blackstone } \\
\text { River Corridor. } \\
\text { Secure funding for } \\
\text { redevelopment and } \\
\text { maintenance of } \\
\text { Library Associations } \\
\text { Centennial Park. } \\
\text { Use CDBG monies for } \\
\text { creating a signage } \\
\text { plan in conjunction } \\
\text { with the BRVNHCC and } \\
\text { the Streetscape } \\
\text { Improvement Program } \\
\text { to appropriately } \\
\text { locate the } \\
\text { recreation resources } \\
\text { in slatersville. }\end{array}$ \\
\hline
\end{tabular}


TABLE 6.3 (con't)

UNDERUTIIIZED RECREATION

\begin{tabular}{|c|c|c|c|}
\hline Goa 1 & objective & Proposal & Implementation \\
\hline $\begin{array}{l}\text { * Encourage } \\
\text { recreation } \\
\text { development and } \\
\text { programs which } \\
\text { emphasize valley } \\
\text { resources and } \\
\text { provide links to } \\
\text { other communities. } \\
\text { * collaborate and } \\
\text { support the corridor } \\
\text { Commission in the } \\
\text { establishment of a } \\
\text { Greenway along the } \\
\text { Blackstone and } \\
\text { Branch Rivers. }\end{array}$ & $\begin{array}{l}\text { Provide proper } \\
\text { signage to alert } \\
\text { residents and } \\
\text { visitors of park } \\
\text { areas. } \\
\text { Provide adequate } \\
\text { pedestrian amenities } \\
\text { throughout } \\
\text { Slatersville, and } \\
\text { provide pedestrian } \\
\text { linkage of park } \\
\text { areas. } \\
\text { * Promote land } \\
\text { conservation and } \\
\text { historic park } \\
\text { restoration through } \\
\text { the Conservation } \\
\text { Commission and Parks } \\
\text { and Recreation } \\
\text { Commission. }\end{array}$ & $\begin{array}{l}\text { Work cooperatively } \\
\text { with the BRVNHC } \\
\text { Commission in } \\
\text { developing signage } \\
\text { for all parks within } \\
\text { the study area, to } \\
\text { be consistent with } \\
\text { the rest of the } \\
\text { Blackstone River } \\
\text { Valley. } \\
\text { Develop a sidewalk } \\
\text { improvement program } \\
\text { for slatersville, } \\
\text { recognizing and } \\
\text { linking the park } \\
\text { facilities. }\end{array}$ & $\begin{array}{l}\text { Apply for CDBG } \\
\text { monies to develop a } \\
\text { sidewalk improvement } \\
\text { program for } \\
\text { slatersville, in } \\
\text { conjunction with the } \\
\text { streetscape } \\
\text { Improvement program } \\
\text { which links all } \\
\text { recreation } \\
\text { facilities. }\end{array}$ \\
\hline
\end{tabular}


TABLE 6.4

BCONOMIC DEVBLOPMENT POTENTIAL

\begin{tabular}{|c|c|c|c|}
\hline Goal & objective & Proposal & Implementation \\
\hline $\begin{array}{l}\text { Foster expansion and } \\
\text { a diversity of } \\
\text { industrial oppor- } \\
\text { tunity areas ranging } \\
\text { from incubator-type } \\
\text { space to further } \\
\text { development of manu- } \\
\text { facturing areas in } \\
\text { old mill buildings, } \\
\text { consistent with } \\
\text { historic structures. } \\
\text { Encourage } \\
\text { redevelopment of } \\
\text { Commercial Block in } \\
\text { slatersville. } \\
\text { * support economic } \\
\text { development which } \\
\text { compliments goals of } \\
\text { the National } \\
\text { Heritage Corridor. }\end{array}$ & $\begin{array}{l}\text { * Implement Programs } \\
\text { to bring necessary } \\
\text { infrastructure to } \\
\text { industrial and } \\
\text { economic development } \\
\text { sites. } \\
\text { * As part of zoning } \\
\text { ordinance revisions, } \\
\text { adopt performance } \\
\text { standards for } \\
\text { industries locating } \\
\text { within the Town. } \\
\text { The town should be } \\
\text { pro-active in terms } \\
\text { of recruiting appro- } \\
\text { priate uses for the } \\
\text { historic buildings } \\
\text { within study area. }\end{array}$ & $\begin{array}{l}\text { * Adaptive reuse of } \\
\text { the slatersville } \\
\text { Mill site as a Mixed } \\
\text { Use development } \\
\text { including offices, } \\
\text { research and } \\
\text { development and } \\
\text { housing. A } \\
\text { feasibility study to } \\
\text { determine the most } \\
\text { appropriate uses is } \\
\text { proposed. } \\
\text { Develop design } \\
\text { recommendations and } \\
\text { implementation } \\
\text { strategies for } \\
\text { streetscape } \\
\text { improvements within } \\
\text { slatersville. }\end{array}$ & $\begin{array}{l}\text { Apply for CDBG } \\
\text { funding to prepare a } \\
\text { feasibility study } \\
\text { for adaptive reuse } \\
\text { of the Slatersville } \\
\text { Mill Complex. } \\
\text { Provide for zone } \\
\text { change necessary to } \\
\text { allow Mixed Use at } \\
\text { the slatersville } \\
\text { Mill Complex. } \\
\text { Coordinate and } \\
\text { provide town funding } \\
\text { or public/private } \\
\text { agreement for } \\
\text { extension of public } \\
\text { water to the Mill } \\
\text { Complex. }\end{array}$ \\
\hline
\end{tabular}


TABLE 6.4 (con't

BCONOMIC DEVELOPHENT POTENTIAL

\begin{tabular}{|c|c|c|c|}
\hline Goal & objective & Proposal & Implementation \\
\hline $\begin{array}{l}\text { * Actively engage in } \\
\text { partnership projects } \\
\text { which are consistent } \\
\text { with goals of the } \\
\text { National Heritage } \\
\text { Corridor. } \\
\text { * Develop an } \\
\text { economic development } \\
\text { strategy that } \\
\text { maintains current } \\
\text { manufacturing } \\
\text { activities, and } \\
\text { targets environ- } \\
\text { mentally sensitive } \\
\text { industry and } \\
\text { business compatible } \\
\text { with historic } \\
\text { surroundings. }\end{array}$ & $\begin{array}{l}\text { Improve visual } \\
\text { appearance of } \\
\text { slatersville more } \\
\text { attractive in terms } \\
\text { of streetscape to } \\
\text { attract new } \\
\text { neighborhood type } \\
\text { businesses. } \\
\text { Encourage local type } \\
\text { services in Commer- } \\
\text { cial Buildings to } \\
\text { make errands more } \\
\text { convenient to nearby } \\
\text { residents while } \\
\text { boosting economic } \\
\text { activity in } \\
\text { slatersville. }\end{array}$ & $\begin{array}{l}\text { * Revise zoning } \\
\text { regulations and } \\
\text { districts as } \\
\text { proposed in the Land } \\
\text { Use Plan Element; } \\
\text { consider special } \\
\text { provisions for } \\
\text { adaptive reuse of } \\
\text { older mill } \\
\text { structures. } \\
\text { Continue the public } \\
\text { private partnership } \\
\text { being utilized to } \\
\text { prepare this guide } \\
\text { plan to insure the } \\
\text { successful } \\
\text { implementation of } \\
\text { the reuse of the } \\
\text { Mill Complex. }\end{array}$ & $\begin{array}{l}\text { * Adopt performance } \\
\text { standards for } \\
\text { Manufacturing Zone } \\
\text { and other districts } \\
\text { if determined } \\
\text { appropriate to } \\
\text { advance } \\
\text { environmental goals } \\
\text { and at the same time } \\
\text { allow industries } \\
\text { which will be } \\
\text { compatible with } \\
\text { their neighbors. } \\
\text { Pro-actively } \\
\text { advocate the } \\
\text { promotion of } \\
\text { slatersville as a } \\
\text { cultural tourist } \\
\text { attraction with the } \\
\text { guidance and } \\
\text { assistance of the } \\
\text { BRvNHcc and } \\
\text { Blackstone valley } \\
\text { Tourism council. }\end{array}$ \\
\hline
\end{tabular}


TABLE 6.5

ZONING

\begin{tabular}{|c|c|c|c|}
\hline Goal & objective & Proposal & Implementation \\
\hline $\begin{array}{l}\text { Revise zoning } \\
\text { ordinance to } \\
\text { accommodate the } \\
\text { appropriate } \\
\text { redevelopment of the } \\
\text { historic structures } \\
\text { within the study } \\
\text { area and the Town. }\end{array}$ & $\begin{array}{l}\text { * Revise zoning } \\
\text { regulations and } \\
\text { districts as } \\
\text { proposed in the Land } \\
\text { Use Plan Element; } \\
\text { consider special } \\
\text { provisions for } \\
\text { adaptive reuse of } \\
\text { older mill } \\
\text { structures. } \\
\text { Provide zoning } \\
\text { regulations which } \\
\text { are most appropriate } \\
\text { to the study area. }\end{array}$ & $\begin{array}{l}\text { Determine } \\
\text { feasibility of } \\
\text { zoning property } \\
\text { behind (east of) } \\
\text { Mill Complex and } \\
\text { North of Branch } \\
\text { River to allow for } \\
\text { recreation and/or } \\
\text { Open Space. } \\
\text { Provide for zone } \\
\text { change necessary to } \\
\text { allow Mixed Use at } \\
\text { the Slatersville } \\
\text { Mill Complex. }\end{array}$ & $\begin{array}{l}\text { Adopt new zoning } \\
\text { regulations which } \\
\text { have been determined } \\
\text { most appropriate to } \\
\text { the study area. } \\
\text { * Adopt performance } \\
\text { standards for } \\
\text { Manufacturing zone. }\end{array}$ \\
\hline
\end{tabular}


TABLE 6.6

CONSTRAINED CIRCULATION

\begin{tabular}{|c|c|c|c|}
\hline Goa 1 & objective & Proposal & Implementation \\
\hline $\begin{array}{l}\text { Provide the best } \\
\text { possible circulation } \\
\text { and parking } \\
\text { throughout the study } \\
\text { area and } \\
\text { slatersville taking } \\
\text { into consideration } \\
\text { and retaining, the } \\
\text { area's significance } \\
\text { as a historic mill } \\
\text { village. }\end{array}$ & $\begin{array}{l}\text { * Take pro-active } \\
\text { role in local } \\
\text { transportation and } \\
\text { DoT projects to have } \\
\text { historic, cultural } \\
\text { and natural features } \\
\text { considered in } \\
\text { design. } \\
\text { Determine if current } \\
\text { parking within study } \\
\text { area is adequate for } \\
\text { full development } \\
\text { scenario. } \\
\text { * Support the } \\
\text { bikeway as an } \\
\text { alternative } \\
\text { transportation route } \\
\text { and } \\
\text { recreational/educat- } \\
\text { ional feature. }\end{array}$ & $\begin{array}{l}\text { Maintain relations } \\
\text { with the state } \\
\text { Historic } \\
\text { Preservation } \\
\text { Commission and } \\
\text { request their } \\
\text { involvement in all } \\
\text { circulation improve- } \\
\text { ments as an advocate } \\
\text { to maintaining } \\
\text { historic character } \\
\text { with respect to } \\
\text { circulation } \\
\text { features. } \\
\text { Develop a parking } \\
\text { analysis for the } \\
\text { study area to } \\
\text { determine if } \\
\text { available parking } \\
\text { will constrain } \\
\text { future uses of the } \\
\text { individual sites. }\end{array}$ & $\begin{array}{l}\text { Implement } \\
\text { recommendations from } \\
\text { parking analysis } \\
\text { through negotiations } \\
\text { with private } \\
\text { developers and } \\
\text { businesses. } \\
\text { Provide improved and } \\
\text { appropriate } \\
\text { circulation signage } \\
\text { as part of the } \\
\text { streetscape } \\
\text { Improvement Program. } \\
\text { Advocate provision } \\
\text { of biking and } \\
\text { pedestrian amenities } \\
\text { in Dot proposal for } \\
\text { stone Arch Bridge } \\
\text { and completion of } \\
\text { Route } 5 \text { improvements } \\
\text { and re-construction. }\end{array}$ \\
\hline
\end{tabular}


TABLE 6.7

\section{INFRASTRUCTURE}

\begin{tabular}{|c|c|c|c|}
\hline Goal & objective & Proposal & Implementation \\
\hline $\begin{array}{l}\text { Provide necessary } \\
\text { infrastructure to } \\
\text { study area which } \\
\text { allows development } \\
\text { commensurate with } \\
\text { other goals. }\end{array}$ & $\begin{array}{l}\text { Insure supply of } \\
\text { public water and } \\
\text { sewer to the study } \\
\text { Area. } \\
\text { Provide } \\
\text { aesthetically at- } \\
\text { tractive electrical } \\
\text { service within } \\
\text { slatersille. }\end{array}$ & $\begin{array}{l}\text { Town should } \\
\text { cooperate with Mill } \\
\text { Complex owners to } \\
\text { insure adequate } \\
\text { infrastructure } \\
\text { facilities for its } \\
\text { redevelopment. } \\
\text { Work with Blackstone } \\
\text { Valley Electric to } \\
\text { develop program for } \\
\text { providing under- } \\
\text { ground utilities } \\
\text { within study area in } \\
\text { compliance with } \\
\text { Statewide Planning } \\
\text { Transportation } \\
\text { Improvement Program. }\end{array}$ & $\begin{array}{l}\text { Implement Programs } \\
\text { to bring necessary } \\
\text { infrastructure to } \\
\text { the slatersville } \\
\text { Mill Complex. } \\
\text { Funding from } \\
\text { Transportation } \\
\text { Enhancement } \\
\text { Activity, Section } \\
1007 \text { of ISTEA. }\end{array}$ \\
\hline
\end{tabular}


TABLE 6.8

POOR STREETSCAPE

\begin{tabular}{|c|c|c|c|}
\hline Goal & objective & Proposa 1 & Implementation \\
\hline $\begin{array}{l}\text { Provide a } \\
\text { streetscape within } \\
\text { the study area which } \\
\text { encourages safe } \\
\text { pedestrian activity, } \\
\text { economic develop- } \\
\text { ment, tourism, and } \\
\text { historic visual } \\
\text { appearance. }\end{array}$ & $\begin{array}{l}\text { * Improve pedestrian } \\
\text { accessibility and } \\
\text { safety in } \\
\text { slatersville. } \\
\text { Improve visual } \\
\text { appearance of the } \\
\text { study area. } \\
\text { Provide a } \\
\text { streetscape in the } \\
\text { study area which } \\
\text { promotes economic } \\
\text { activity. }\end{array}$ & $\begin{array}{l}\text { Develop a street- } \\
\text { scape Improvement } \\
\text { Program with } \\
\text { pedestrian crossings } \\
\text { marked on the } \\
\text { pavement. } \\
\text { Develop streetscape } \\
\text { Design Guidelines } \\
\text { which are harmonious } \\
\text { with the historic } \\
\text { and cultural } \\
\text { character of } \\
\text { slatersville. }\end{array}$ & $\begin{array}{l}\text { Implement the } \\
\text { Streetscape } \\
\text { Improvement Program } \\
\text { and Streetscape } \\
\text { Design Guidelines } \\
\text { with ISTEA/TIP } \\
\text { monies, specifically } \\
\text { those monies } \\
\text { provided for } \\
\text { Transporation Enhan- } \\
\text { cement Activity. }\end{array}$ \\
\hline
\end{tabular}




\subsection{CONCLUSION}

This study has a 5 to 10 year time frame. The Town of North Smithfield asserts that "the next few years promise to be a period of relatively austere finances at the local, state and Federal levels. Grant funds formerly available to municipalities such as North Smithfield have in many cases been drastically reduced or eliminated." Therefore projects which can expand employment opportunities and beneficially add to the Town's tax base should be given priority. Although North Smithfield has a limited number of professionals available to draft regulatory changes and develop programs, a period of slower community development may free up some time for such work.

Since funding is severely constrained at the local level, several federal sources of programming and funding should be actively pursued in order to insure successful implementation of this Guide Plan. These include funding resulting from the new Intermodal Surface Transportation Efficiency Act (ISTEA). Local funding will be available through "Metropolitan Planning", including the Transportation Improvement Program (TIP) and Transportation Enhancement Activities, such as the Scenic Trails Program. Slatersville must coordinate with the state Improvement Plan (SIP) to be developed by Statewide Planning as the Metropolitan Planning Agency. Active dialog with Statewide Planning will help to insure maximum benefits to North Smithfield and Slatersville through program development and funding recommendations. 
Another source of programming and funding which should be actively pursued are those associated with the Blackstone River Valley National Heritage Corridor designation. This will benefit North Smithfield and Slatersville through a coordinated approach to recreation, tourism and economic development. The recent creation of the Northern Rhode Island Economic Development Partnership, which combines the efforts of five agencies as well as the northern Rhode Island city and town cooperation, will benefit the economy regionally as one coordinated effort. 


\section{BIBI.IOGRAPHY}

Albert Veri and Associates, Inc., in association with Ryan, Elliott Appraisal and Consulting Company, Inc. Phase one Final Report, Site Development Potential and Development Recommendations for Branch River Industrial Park and Adjacent Properties, North Smithfield, RI. December, 1987.

Barnett, J. The Elusive City. New York: Harper and Row, 1986. Chapter 4, "Urban Design and the Preservation Movement".

Blackstone River Valley National Heritage Corridor Commission and state Planning Council, state of RI. Cultural Heritage and Land Management Plan for the Blackstone River Valley National Heritage Corridor. State Guide Plan Element 131. September, 1990 .

Blackstone River Valley National Heritage Corridor Commission. "Grant Application for Slatersville Project". June 1992.

Burk Ketcham and Associates. North Smithfield Comprehensive Plan. F-Economic Development, G-Natural and Cultural Resources, K-Blackstone River Valley National Heritage Corridor, L-Implementation. October 1991.

Dennison, Mark S. Conservation Districts: Latest Zoning Tool to Preserve Neighborhood Character. Zoning News, American Planning Association. November, 1992.

Gale, Dennis, E. The Impacts of Historic District Designation, Planning and Policy Implications. APA Journal, 325. Summer, 1991 .

Gates, Leighton, and Associates, Inc. Master Plan - Valley Falls Heritage Park, Cumberland, Rhode Island. 1991.

Lee Pare \& Associates, Inc. and Everett Associates. Blackstone Linear Park, Overview and Guide Plan. January, 1985.

Lynch, Kevin. The Image of the City. Cambridge, MA: MIT Press. 1960 .

Lynch, Kevin. A Theory of Good City Form. Cambridge, MA: MIT Press. 1981.

Meservey, George Daniel, III. Mill preservation in the Blackstone River Valley, A Research Priject Submitted in Partial Fulfillment of the Requirements for the Degree of Master of Community Planning. The University of Rhode Island. 1992 . 
Mowry, William A. - The Village of slatersville sixty Years Ago.

Municipal Code Corporation. The Town of North Smithfield Zoning ordinance. Published by the Municipal Code Corporation, Tallahassee, Fla. 1991.

The Rhode Island Historical Preservation Commission. Easy Guide To Rehab Standards. 1992.

The Rhode Island Historical Preservation Commission. The Rhode Island Historic Preservation Plan. June, 1989.

Shirvani, H. The Urban Design Process. New York: Van Nostrand Reinhold, 1985. Chapter 2 "Elements of Urban Physical Form", Chapter 9, "Implementation: Legal Mechanisms".

Shirvani, H. The Urban Design Review: A Guide for Planners. Chicago: Planners Press, 1981. Chapter 10, "Implementation: Financial Mechanisms".

State of Rhode Island, Department of Environmental Management. Blackstone River Park Master Plan. June, 1986.

Steere, Thomas. History of the Town of smithfield, From its organization, in 1730-1, to its Division in 1871. E.L. Freeman \& Co. 1881 .

Steffens, Richard. What the Incubators Have Hatched. Planning, Vol. 58, No. 5. (p. 28). May, 1992 .

Trancik, Roger. Finding Lost Space, Theories of Urban Design. Van Nostrand Reinhold Company, New York. Chapter 4.

Tyrrell, Timothy J., Ph.D. and Patt Manheim, Ph.D. Economic Assessment of Blackstone Valley National Heritage Corridor. Office of Travel, Tourism, and Recreation Department of Resource Economics, The University of RI. November 1989.

Urban Land Institute. Adaptive Use. Washington: ULI. 1980.

Urban Land Instutute. Project Reference File. Washington: ULI. 1980. Volume $8-21$.

Wilcox, Michael, B. A Development Strategy for the Adaptive Reuse of the Newport steam Mill. A Research Project. 1985. 